\title{
Manganese-Catalyzed Borylation of Unactivated Alkyl Chlorides
}

Thomas C. Atack and Silas P. Cook*

Department of Chemistry, Indiana University,

800 East Kirkwood Avenue, Bloomington, IN 47405-7102

Supporting Information

\section{Table of Contents}

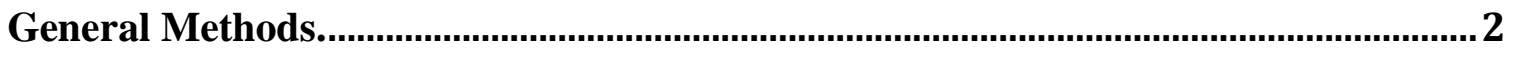

Experimental Procedures and Characterization........................................................... 3

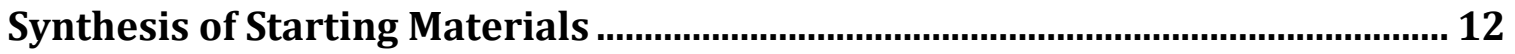

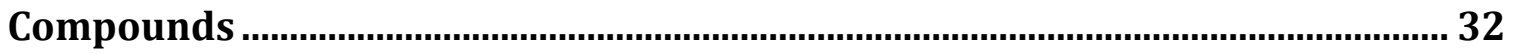

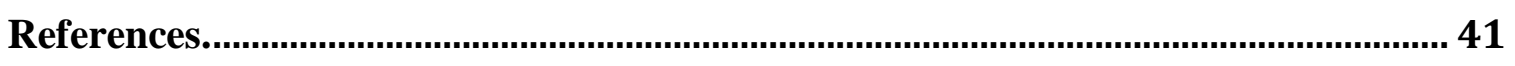

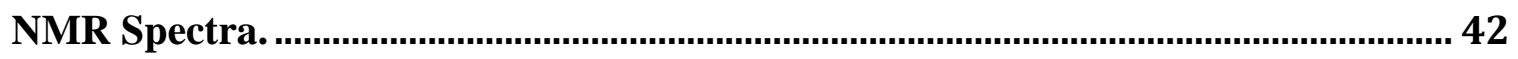


General Methods.

All the reactions were carried out in flame-dried glassware fitted with rubber septa under a nitrogen atmosphere unless otherwise stated. Analytical grade solvents and commercially available reagents were purchased from commercial sources and used directly without further purification unless otherwise stated. THF and DME were purified according to the Grubbs procedure. ${ }^{1}$ Thin-layer chromatography (TLC) was carried out on Merck 60 F254 precoated, glass silica gel plates which were visualized with either ultraviolet light or stained with $\mathrm{KMnO}_{4}$ or vanillin. Automated column chromatography was performed on a Biotage Isolera One using Biotage Snap cartridges (25g or $50 \mathrm{~g} \mathrm{SiO}_{2}$ ), Yamzen universal columns (16g $\left.40 \mu \mathrm{m} \mathrm{SiO} 2\right)$, or RediSepRf columns (24g or $40 \mathrm{~g} \mathrm{SiO}_{2}$ ) monitoring wavelengths $254 \mathrm{~nm}$ and $280 \mathrm{~nm}$ unless otherwise noted. ${ }^{1} \mathrm{H}$-NMR and ${ }^{13} \mathrm{C}$-NMR spectra were recorded at room temperature using a Varian I400 $\left({ }^{1} \mathrm{H}-\mathrm{NMR}\right.$ at $400 \mathrm{MHz}$ and ${ }^{13} \mathrm{C}-\mathrm{NMR}$ at $\left.100 \mathrm{MHz}\right)$, Varian VXR400 $\left({ }^{1} \mathrm{H}-\mathrm{NMR}\right.$ at $400 \mathrm{MHz}$ and ${ }^{13} \mathrm{C}-\mathrm{NMR}$ at $\left.100 \mathrm{MHz}\right)$, Varian $\mathrm{I} 500\left({ }^{1} \mathrm{H}-\right.$ $\mathrm{NMR}$ at $500 \mathrm{MHz}$ and ${ }^{13} \mathrm{C}$-NMR at $125 \mathrm{MHz}$ ). Chemical shifts are reported in ppm with reference to solvent signals [ ${ }^{1} \mathrm{H}-\mathrm{NMR}$ : $\mathrm{CDCl}_{3}$ (7.26 ppm); ${ }^{13} \mathrm{C}-\mathrm{NMR}$ : $\mathrm{CDCl}_{3}(77.16$ ppm)]. Signal patterns are indicated as s, singlet; d, doublet; $t$, triplet; q, quartet; and $\mathrm{m}$, multiplet. The boron-bonded carbon atom was not detected, due to quadrupolar broadening by the ${ }^{11} \mathrm{~B}$ nucleus. Infrared spectra (IR) were obtained on an Avatar 360-FT IR E.S.P. on a NaCl salt plate and recorded in wavenumbers $\left(\mathrm{cm}^{-1}\right)$. Chiral high performance liquid chromatography (HPLC) was performed on an Agilent Technologies 1220 infinity LC equipped with a Phenomenex Lux Cellulose 1 column (250mm X 4.6mm, Cellulose tris(3,5-dimethylphenylcarbamate), detector $=U V$, $280 \mathrm{~nm}$, temperature $\left.=24^{\circ} \mathrm{C}\right)$ or a Phenomenex Lux Cellulose 2 column $(250 \mathrm{~mm} \mathrm{X}$ $4.6 \mathrm{~mm}$, Cellulose tris(3-chloro-4-methylphenylcarbamate), detector $=U V, 280 \mathrm{~nm}$, temperature $=24^{\circ} \mathrm{C}$ ). High Resolution Mass (HRMS) analysis was obtained using Electron Impact Ionization (EI) and reported as $\mathrm{m} / \mathrm{z}$ (relative intensity) for the molecular ion [M], or with Electrospray Ionization (ESI) and reporting the molecular ion $[\mathrm{M}+\mathrm{H}]^{+}$or a suitable fragment ion. 
Experimental Procedures and Characterization.

Table 1: Solvent Screen

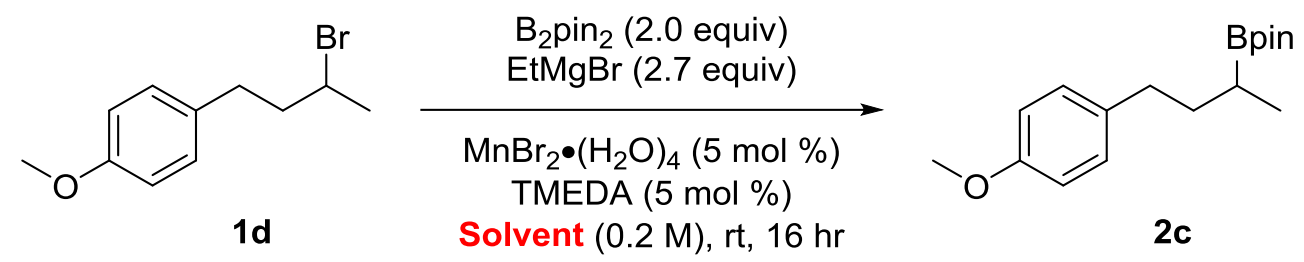

\begin{tabular}{c|c|ccc|c|c} 
Entry & Solvent & Yield $^{\mathrm{a}}$ & & Entry & Solvent & Yield $^{\mathrm{a}}$ \\
\hline 1 & $\mathrm{THF}$ & $88 \%$ & & 7 & Dioxane & $19 \%$ \\
2 & $\mathrm{DMF}$ & $5 \%$ & & 8 & DME & $95 \%$ \\
3 & $\mathrm{MeCN}$ & $<1 \%$ & & 9 & $2-\mathrm{MeTHF}$ & $46 \%$ \\
4 & $\mathrm{DCM}$ & $<1 \%$ & & 10 & $\mathrm{MTBE}$ & $1 \%$ \\
5 & $\mathrm{Et}_{2} \mathrm{O}$ & $<1 \%$ & & 11 & $\mathrm{Ipr}_{2} \mathrm{O}$ & $<1 \%$ \\
6 & Toluene & $<1 \%$ & & 12 & $\mathrm{NMP}$ & $36 \%$
\end{tabular}

a Yield determined by GC using dodecane as an internal standard.

A flame-dried vial was charged with $\mathrm{MnBr}_{2} \bullet\left(\mathrm{H}_{2} \mathrm{O}\right)_{4}(3.6 \mathrm{mg}, 5 \mathrm{~mol} \%)$ and $\mathrm{B}_{2}$ pin 2 (127.0 mg, 2.0 equiv) before evacuating and back-filling with $\mathrm{N}_{2}$. Solvent $(1.25 \mathrm{~mL}$, $0.2 \mathrm{M}$ ) was added, followed by TMEDA ( $2 \mu \mathrm{L}, 5 \mathrm{~mol} \%$ ) and dodecane (57 $\mu \mathrm{L}, 42.7$ $\mathrm{mg}, 0.25 \mathrm{mmol}, 1$ equiv). Next, ethylmagnesium bromide (3M in Et $\mathrm{E}_{2} \mathrm{O}, 225 \mu \mathrm{L} 2.7$ equiv) was added dropwise to the reaction mixture at a rate of two drops/sec (approximately $10 \mathrm{sec}$ total addition time). Finally, 1-(3-bromobutyl)-4methoxybenzene ( $48 \mu \mathrm{L}, 60.5 \mathrm{mg}, 0.25 \mathrm{mmol}, 1$ equiv) was added the reaction mixture at once. The reaction mixture was stirred at room temperature for $16 \mathrm{hr}$. Reactions were quenched with $\mathrm{HCl}(2 \mathrm{~mL}, 1 \mathrm{M})$, diluted with $\mathrm{Et}_{2} \mathrm{O}(5 \mathrm{~mL})$ and the mixture was shaken vigorously until colorless. A $500 \mu \mathrm{L}$ aliquot of the organic layer was transferred to a $1.5 \mathrm{~mL} \mathrm{GC}$ vial, diluted with an additional $1 \mathrm{~mL} \mathrm{Et}{ }_{2} \mathrm{O}$, and analyzed directly by GC. 
Table 2: Mn Source Screen

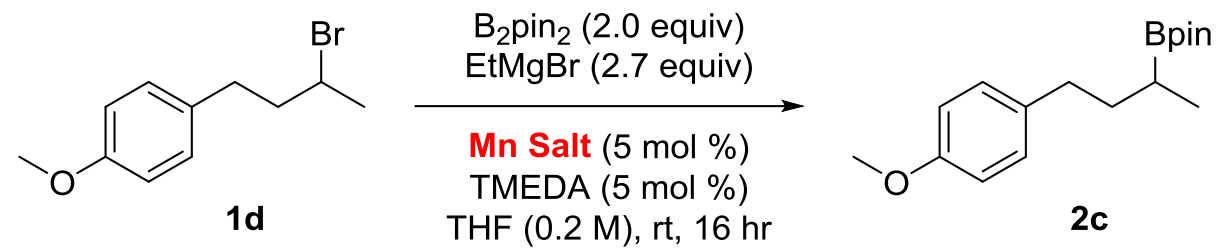

\begin{tabular}{c|c|c} 
Entry & $\mathrm{Mn} \mathrm{Salt}$ & Yield $^{\mathrm{a}}$ \\
\hline 1 & $\mathrm{MnBr}_{2}$ & $81 \%$ \\
2 & $\mathrm{MnBr}_{2} \bullet\left(\mathrm{H}_{2} \mathrm{O}\right)_{4}$ & $81 \%$ \\
3 & $\mathrm{MnF}_{2}$ & $29 \%$ \\
4 & $\mathrm{MnF}_{3}$ & $47 \%$ \\
5 & $\mathrm{Mn}(\mathrm{OAc})_{3} \bullet\left(\mathrm{H}_{2} \mathrm{O}\right)_{2}$ & $58 \%$ \\
6 & $\mathrm{Mn}(\mathrm{OAc})_{2} \bullet\left(\mathrm{H}_{2} \mathrm{O}\right)_{4}$ & $67 \%$ \\
7 & $\mathrm{Mn}(\mathrm{acac})_{2}$ & $81 \%$ \\
8 & $\mathrm{Mn}(\mathrm{acac})_{3}$ & $68 \%$ \\
\hline
\end{tabular}

a Yield determined by GC using dodecane as an internal standard.

A flame-dried vial was charged with the manganese source (5 mol \%) and $\mathrm{B}_{2}$ pin 2 (127.0 mg, 2.0 equiv) before evacuating and back-filling with $\mathrm{N}_{2}$. THF $(1.25 \mathrm{~mL}, 0.2$ M) was added, followed by TMEDA ( $2 \mu \mathrm{L}, 5 \mathrm{~mol} \%)$ and dodecane (57 $\mu \mathrm{L}, 42.7 \mathrm{mg}$, $0.25 \mathrm{mmol}, 1$ equiv). Next, ethylmagnesium bromide (3M in $\mathrm{Et}_{2} \mathrm{O}, 225 \mu \mathrm{L} 2.7$ equiv) was added dropwise to the reaction mixture at a rate of two drops/sec (approximately $10 \mathrm{sec}$ total addition time). Finally, 1-(3-bromobutyl)-4methoxybenzene ( $48 \mu \mathrm{L}, 60.5 \mathrm{mg}, 0.25 \mathrm{mmol}, 1$ equiv) was added the reaction mixture at once. The reaction mixture was stirred at room temperature for $16 \mathrm{hr}$. Reactions were quenched with $\mathrm{HCl}(2 \mathrm{~mL}, 1 \mathrm{M})$, diluted with $\mathrm{Et}_{2} \mathrm{O}(5 \mathrm{~mL})$ and the mixture was shaken vigorously until colorless. A $500 \mu \mathrm{L}$ aliquot of the organic layer was transferred to a $1.5 \mathrm{~mL} \mathrm{GC}$ vial, diluted with an additional $1 \mathrm{~mL} \mathrm{Et} 2 \mathrm{O}$, and analyzed directly by GC. 
Table 3: Timecourse

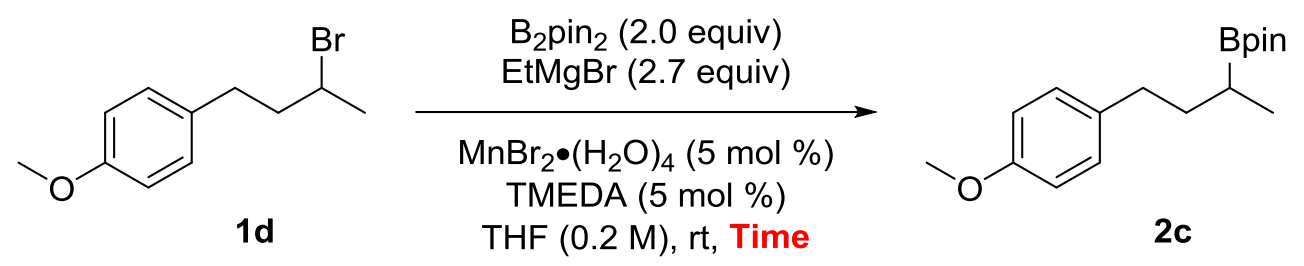

\begin{tabular}{c|c|c} 
Entry & Time & Yield $^{\mathrm{a}}$ \\
\hline 1 & $5 \mathrm{~min}$ & $33 \%$ \\
2 & $30 \mathrm{~min}$ & $66 \%$ \\
3 & $1 \mathrm{hr}$ & $74 \%$ \\
4 & $2 \mathrm{hr}$ & $80 \%$ \\
5 & $3 \mathrm{hr}$ & $82 \%$ \\
6 & $4 \mathrm{hr}$ & $83 \%$ \\
7 & $17 \mathrm{hr}$ & $80 \%$
\end{tabular}

a Yield determined by GC using dodecane as an internal standard.

A flame-dried vial was charged with $\mathrm{MnBr}_{2} \bullet\left(\mathrm{H}_{2} \mathrm{O}\right)_{4}(7.2 \mathrm{mg}, 5 \mathrm{~mol} \%)$ and $\mathrm{B}_{2}$ pin 2 (254.0 mg, 2.0 equiv) before evacuating and back-filling with $\mathrm{N}_{2}$. THF (2.5 mL, 0.2 M) was added, followed by TMEDA ( $4 \mu \mathrm{L}, 5 \mathrm{~mol} \%$ ) and dodecane (57 $\mu \mathrm{L}, 42.7 \mathrm{mg}$, $0.25 \mathrm{mmol}, 0.5$ equiv). Next, ethylmagnesium bromide ( $3 \mathrm{M}$ in Et $\mathrm{E}_{2} \mathrm{O}, 450 \mu \mathrm{L} 2.7$ equiv) was added dropwise to the reaction mixture at a rate of two drops/sec (approximately $10 \mathrm{sec}$ total addition time). Finally, 1-(3-bromobutyl)-4methoxybenzene $(96.5 \mu \mathrm{L}, 121.6 \mathrm{mg}, 0.5 \mathrm{mmol}, 1$ equiv) was added the reaction mixture at once. The reaction mixture was stirred at room temperature. At the indicated times, $50 \mu \mathrm{L}$ aliquots were removed from the reaction vial, flushed through a plug of silica gel with $\mathrm{Et}_{2} \mathrm{O}(2 \times 750 \mu \mathrm{L})$, and analyzed directly by GC. 
Table 4: Grignard Equivalents

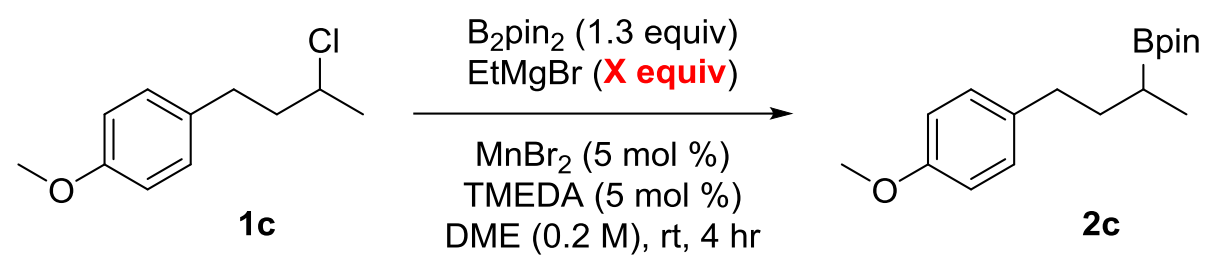

\begin{tabular}{c|c|c} 
Entry & $\mathrm{X}$ & Yield $^{\mathrm{a}}$ \\
\hline 1 & 1.7 & $71 \%$ \\
2 & 1.6 & $68 \%$ \\
3 & 1.5 & $85 \%$ \\
4 & 1.4 & $88 \%$ \\
5 & 1.3 & $85 \%$ \\
6 & 1.2 & $78 \%$
\end{tabular}

a Yield determined by GC using dodecane as an internal standard.

A flame-dried vial was charged with $\mathrm{MnBr}_{2}(2.7 \mathrm{mg}$, $5 \mathrm{~mol} \%$ ) and B2pinz (82.5 mg, 1.3 equiv) before evacuating and back-filling with $\mathrm{N}_{2}$. DME (1.25 mL, $\left.0.2 \mathrm{M}\right)$ was added, followed by TMEDA ( $2 \mu \mathrm{L}, 5 \mathrm{~mol} \%$ ) and dodecane ( $57 \mu \mathrm{L}, 42.7 \mathrm{mg}, 0.25$ mmol, 1 equiv). Next, ethylmagnesium bromide (3M in $\mathrm{Et}_{2} \mathrm{O}, \mathrm{X}$ equiv) was added dropwise to the reaction mixture at a rate of two drops/sec (approximately 10-15 sec total addition time). Finally, 1-(3-chlorobutyl)-4-methoxybenzene ( $47.5 \mu \mathrm{L}, 49.9$ $\mathrm{mg}, 0.25 \mathrm{mmol}, 1$ equiv) was added the reaction mixture at once. The reaction mixture was stirred at room temperature for $4 \mathrm{hr}$. Reactions were quenched with $\mathrm{HCl}(2 \mathrm{~mL}, 1 \mathrm{M})$, diluted with $\mathrm{Et}_{2} \mathrm{O}(5 \mathrm{~mL})$ and the mixture was shaken vigorously until colorless. A $500 \mu \mathrm{L}$ aliquot of the organic layer was transferred to a $1.5 \mathrm{~mL} \mathrm{GC}$ vial, diluted with an additional $1 \mathrm{~mL} \mathrm{Et}{ }_{2} \mathrm{O}$, and analyzed directly by GC. 
Table 5: Ligand Screen

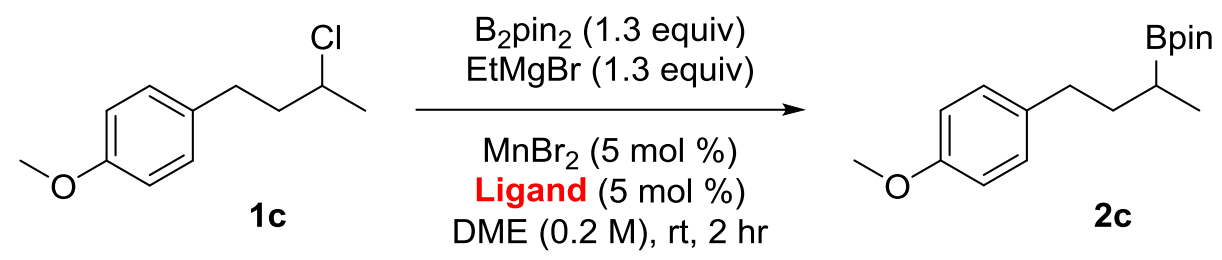

\begin{tabular}{c|c|ccc|c|c} 
Entry & Ligand & Yield $^{\mathrm{a}}$ & & Entry & Ligand & Yield $^{\mathrm{a}}$ \\
\cline { 1 - 2 } \cline { 5 - 6 } 1 & None & $2 \%$ & & 7 & PPh3 & $2 \%$ \\
2 & TMEDA & $73 \%$ & & 8 & TMCyDA & $19 \%$ \\
3 & TMEDA $^{\mathrm{b}}$ & $79 \%$ & & 9 & IPr & $2 \%$ \\
4 & TMEDA $^{\mathrm{c}}$ & $72 \%$ & & 10 & NEt3 & $19 \%$ \\
5 & EDA & $27 \%$ & & 11 & BIPY & $0 \%$ \\
6 & dppe & $0 \%$ & & 12 & Pyridine & $1 \%$
\end{tabular}

a Yield determined by GC using dodecane as an internal standard.

${ }^{\mathrm{b}} 25 \mathrm{~mol} \%$ added. ${ }^{\mathrm{c}} 1$ equiv added

A flame-dried vial was charged with $\mathrm{MnBr}_{2}(2.7 \mathrm{mg}, 5 \mathrm{~mol} \%$ ), B2pin 2 (82.5 mg, 1.3 equiv), and ligand (if solid, $5 \mathrm{~mol} \%$, entries $6,7,9,11$ ) before evacuating and backfilling with $\mathrm{N}_{2}$. DME (1.25 mL, $0.2 \mathrm{M}$ ) was added, followed by ligand (if liquid, $5 \mathrm{~mol}$ $\%$, entries $2-5,8,10,12)$ and dodecane $(57 \mu \mathrm{L}, 42.7 \mathrm{mg}, 0.25 \mathrm{mmol}, 1$ equiv). Next, ethylmagnesium bromide (3M in $\mathrm{Et}_{2} \mathrm{O}, 110 \mu \mathrm{L}, 1.3$ equiv) was added dropwise to the reaction mixture at a rate of two drops/sec (approximately $10 \mathrm{sec}$ total addition time). Finally, 1-(3-chlorobutyl)-4-methoxybenzene ( $47.5 \mu \mathrm{L}, 49.9 \mathrm{mg}, 0.25 \mathrm{mmol}, 1$ equiv) was added the reaction mixture at once. The reaction mixture was stirred at room temperature for $2 \mathrm{hr}$. Reactions were quenched with $\mathrm{HCl}(2 \mathrm{~mL}, 1 \mathrm{M})$, diluted with $\mathrm{Et}_{2} \mathrm{O}(5 \mathrm{~mL})$ and the mixture was shaken vigorously until colorless. A $500 \mu \mathrm{L}$ aliquot of the organic layer was transferred to a $1.5 \mathrm{~mL} \mathrm{GC}$ vial, diluted with an additional $1 \mathrm{~mL} \mathrm{Et}_{2} \mathrm{O}$, and analyzed directly by GC. 
Table 6: Concentration Effects

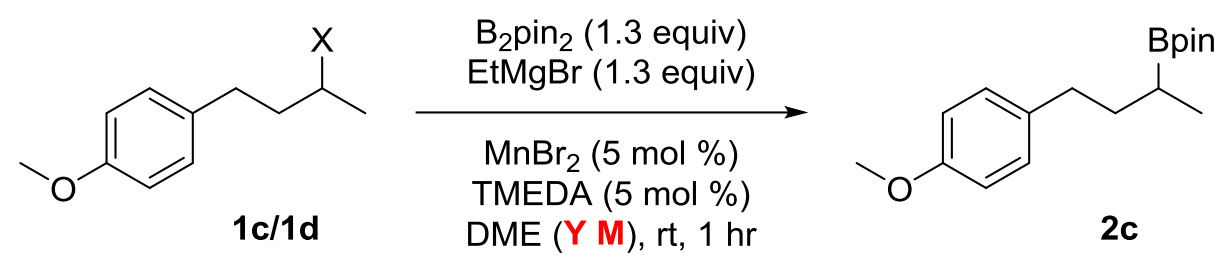

\begin{tabular}{c|c|c|c} 
Entry & $\mathrm{Y}$ & Yield $^{\mathrm{a}} \mathrm{X}=\mathrm{Cl}$ & Yield $^{\mathrm{a}} \mathrm{X}=\mathrm{Br}$ \\
\hline 1 & $0.05 \mathrm{M}$ & $60 \%$ & $90 \%$ \\
2 & $0.2 \mathrm{M}$ & $67 \%$ & $82 \%$ \\
3 & $1.0 \mathrm{M}$ & $78 \%$ & $86 \%$
\end{tabular}

a Yield determined by GC using dodecane as an internal standard.

A flame-dried vial was charged with $\mathrm{MnBr}_{2}\left(2.7 \mathrm{mg}, 5 \mathrm{~mol} \%\right.$ ) and $\mathrm{B}_{2}$ pin 2 (82.5 mg, 1.3 equiv) before evacuating and back-filling with $\mathrm{N}_{2}$. DME (Y M) was added, followed by TMEDA ( $2 \mu \mathrm{L}, 5 \mathrm{~mol} \%$ ) and dodecane ( $57 \mu \mathrm{L}, 42.7 \mathrm{mg}, 0.25 \mathrm{mmol}, 1$ equiv). Next, ethylmagnesium bromide (3M in Et $20,110 \mu \mathrm{L}, 1.3$ equiv) was added dropwise to the reaction mixture at a rate of two drops/sec (approximately $10 \mathrm{sec}$ total addition time). Finally, substrate $(0.25 \mathrm{mmol}, 1$ equiv) was added the reaction mixture at once. The reaction mixture was stirred at room temperature for $1 \mathrm{hr}$. Reactions were quenched with $\mathrm{HCl}(2 \mathrm{~mL}, 1 \mathrm{M})$, diluted with $\mathrm{Et}_{2} \mathrm{O}(5 \mathrm{~mL})$ and the mixture was shaken vigorously until colorless. A $500 \mu \mathrm{L}$ aliquot of the organic layer was transferred to a $1.5 \mathrm{~mL} \mathrm{GC}$ vial, diluted with an additional $1 \mathrm{~mL} \mathrm{Et} \mathrm{O}_{2} \mathrm{O}$, and analyzed directly by GC. 
Table 7: Manganese Loading

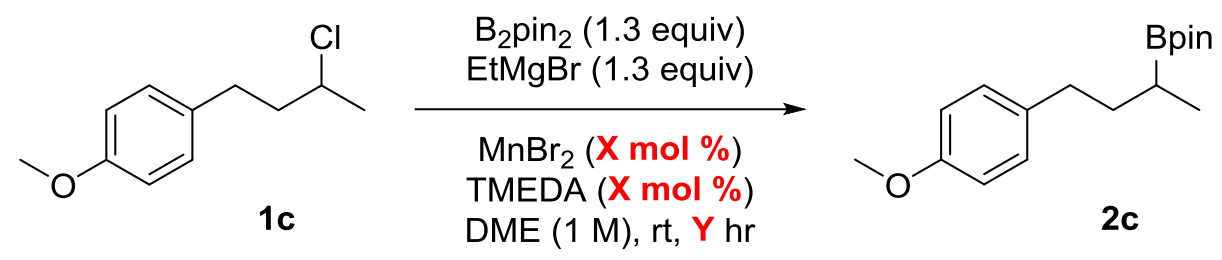

\begin{tabular}{c|c|c|c|c} 
Entry $^{\mathrm{a}}$ & $\mathrm{X}$ & \multicolumn{3}{|c}{$\mathrm{Y}$} \\
\hline & & $0.5 \mathrm{hr}$ & $1 \mathrm{hr}$ & $4 \mathrm{hr}$ \\
\cline { 3 - 5 } 1 & $1 \%$ & $30 \%$ & $47 \%$ & $79 \%$ \\
2 & $5 \%$ & $78 \%$ & $78 \%$ & $82 \%$ \\
3 & $10 \%$ & $70 \%$ & $73 \%$ & $77 \%$
\end{tabular}

a Yield determined by GC using dodecane as an internal standard.

A flame-dried vial was charged with $\mathrm{MnBr}_{2}$ (X mol \%), $\mathrm{B}_{2} \mathrm{pin}_{2}$ (82.5 mg, 1.3 equiv) before evacuating and back-filling with $\mathrm{N}_{2}$. DME $(250 \mu \mathrm{L}, 1.0 \mathrm{M})$ was added, followed by TMEDA (X mol \%) and dodecane ( $57 \mu \mathrm{L}, 42.7 \mathrm{mg}, 0.25 \mathrm{mmol}, 1$ equiv). Next, ethylmagnesium bromide (3M in $\mathrm{Et}_{2} \mathrm{O}, 110 \mu \mathrm{L}, 1.3$ equiv) was added dropwise to the reaction mixture at a rate of two drops/sec (approximately $10 \mathrm{sec}$ total addition time). Finally, 1-(3-chlorobutyl)-4-methoxybenzene ( $47.5 \mu \mathrm{L}, 49.9 \mathrm{mg}, 0.25$ mmol, 1 equiv) was added the reaction mixture at once. The reaction mixture was stirred at room temperature. At the indicated times, $50 \mu \mathrm{L}$ aliquots were removed from the reaction vial, flushed through a plug of silica gel with $\mathrm{Et}_{2} \mathrm{O}(2 \times 750 \mu \mathrm{L})$, and analyzed directly by GC. 
Scheme 1: Relative Rates of Borylation in THF vs. DME
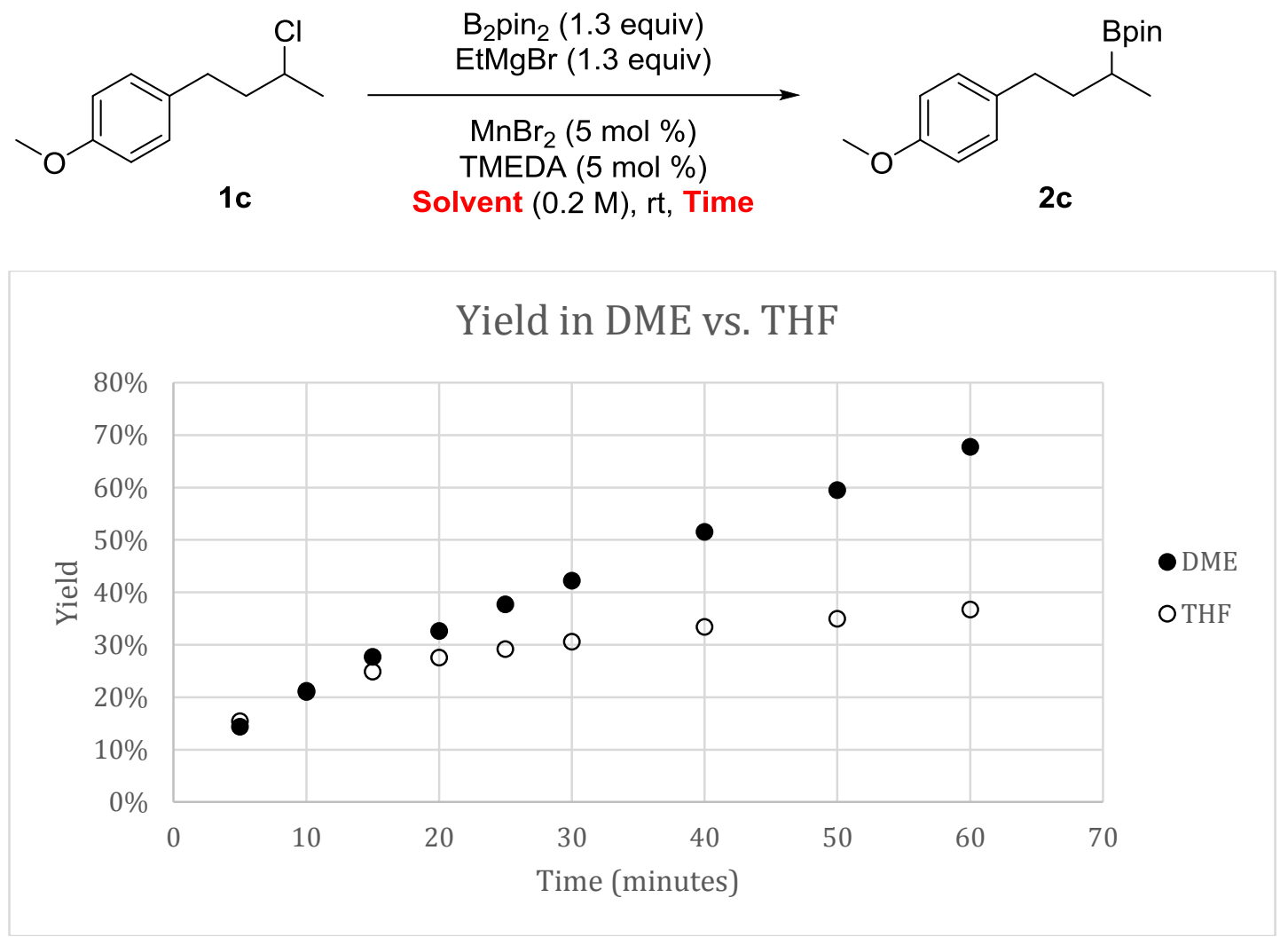

A flame-dried vial was charged with $\mathrm{MnBr}_{2}(2.7 \mathrm{mg}, 5 \mathrm{~mol} \%)$ and B2pin2 (82.5 mg, 1.3 equiv) before evacuating and back-filling with $\mathrm{N}_{2}$. Solvent (1.25 mL, 0.2 M) was added, followed by TMEDA ( $2 \mu \mathrm{L}, 5 \mathrm{~mol} \%$ ) and dodecane (57 $\mu \mathrm{L}, 42.7 \mathrm{mg}, 0.25$ mmol, 1 equiv). Next, ethylmagnesium bromide (3M in Et $20,110 \mu \mathrm{L}, 1.3$ equiv) was added dropwise to the reaction mixture at a rate of two drops/sec (approximately $10 \mathrm{sec}$ total addition time). Finally, 1-(3-chlorobutyl)-4-methoxybenzene $(47.5 \mu \mathrm{L}$, $0.25 \mathrm{mmol}, 1$ equiv) was added the reaction mixture at once. The reaction mixture was stirred at room temperature. At the indicated times, $50 \mu \mathrm{L}$ aliquots were removed from the reaction vial, flushed through a plug of silica gel with $\mathrm{Et}_{2} \mathrm{O}(2 \times 750$ $\mu \mathrm{L}$ ), and analyzed directly by GC. 


\section{Competition Reactions}

Standard Competition Reactions: A flame-dried vial was charged with $\operatorname{MnBr}_{2}(1.1$ mg, $1 \mathrm{~mol} \%$ ) and B2pin2 (165.1 mg, 1.3 equiv) before evacuating and back-filling with $\mathrm{N}_{2}$. DME (2.5 mL, 0.2 M) was added followed by 1 mol \% TMEDA (10 $\mu \mathrm{L}$ of a $4 \%(\mathrm{v} / \mathrm{v})$ solution of TMEDA in DME). Next, ethylmagnesium bromide (3M in Et 20 , $220 \mu \mathrm{L}, 1.3$ equiv) was added dropwise to the reaction mixture at a rate of two drops/sec (approximately $20 \mathrm{sec}$ total addition time). Finally, a 1:1:1 mixture of substrate A ( $0.25 \mathrm{mmol}, 0.5$ equiv), substrate B ( $0.25 \mathrm{mmol}, 0.5$ equiv), and dodecane internal standard ( $57 \mu \mathrm{L}, 0.25 \mathrm{mmol}$ ) was dissolved in $100 \mu \mathrm{L}$ DME added to the reaction mixture at once. The reaction mixture was stirred at room temperature for the indicated time. Reactions were quenched with $\mathrm{HCl}(2 \mathrm{~mL}, 1 \mathrm{M})$, diluted with $\mathrm{Et}_{2} \mathrm{O}(5 \mathrm{~mL})$ and the mixture was shaken vigorously until colorless. A $500 \mu \mathrm{L}$ aliquot of the organic layer was transferred to a $1.5 \mathrm{~mL}$ GC vial, diluted with an additional $1 \mathrm{~mL} \mathrm{Et}{ }_{2} \mathrm{O}$, and analyzed directly by GC.

$\boldsymbol{\alpha}$-Chloro Boronic Ester Competition: A flame-dried vial was charged with $\mathrm{Mn}$ (hfacac) 2 (tmeda) (100 $\mu \mathrm{L}$ of a solution made up of $7.4 \mathrm{mg} \mathrm{Mn}$ (hfacac)2(tmeda) dissolved in $1 \mathrm{~mL}$ DME, $0.25 \mathrm{~mol} \%$ ) and B2pin2 (165.1 mg, 1.3 equiv) before evacuating and back-filling with $\mathrm{N}_{2}$ and DME $(2.5 \mathrm{~mL}, 0.2 \mathrm{M})$ was added. Next, ethylmagnesium bromide ( $3 \mathrm{M}$ in $\mathrm{Et}_{2} \mathrm{O}, 220 \mu \mathrm{L}, 1.3$ equiv) was added dropwise to the reaction mixture at a rate of two drops/sec (approximately $20 \mathrm{sec}$ total addition time). Finally, a 1:1:1 mixture of substrate A ( $0.25 \mathrm{mmol}, 0.5$ equiv), substrate B ( $0.25 \mathrm{mmol}, 0.5$ equiv), and dodecane internal standard ( $57 \mu \mathrm{L}, 0.25 \mathrm{mmol}$ ) was dissolved in $100 \mu \mathrm{L}$ DME added to the reaction mixture at once. The reaction mixture was stirred at room temperature for 10 minutes. Reactions were quenched with $\mathrm{HCl}(2 \mathrm{~mL}, 1 \mathrm{M})$, diluted with $\mathrm{Et}_{2} \mathrm{O}(5 \mathrm{~mL})$ and the mixture was shaken vigorously until colorless. A $500 \mu \mathrm{L}$ aliquot of the organic layer was transferred to a $1.5 \mathrm{~mL} \mathrm{GC}$ vial, diluted with an additional $1 \mathrm{~mL} \mathrm{Et}{ }_{2} \mathrm{O}$, and analyzed directly by GC. 


\title{
Synthesis of Starting Materials
}

\author{
$\mathrm{Mn}(\mathrm{OAC})_{2}\left(\mathrm{H}_{2} \mathrm{O}\right)_{4} \underset{\mathrm{DCM}, \text { reflux, } 1 \mathrm{~h}}{\stackrel{\text { hfacac, tmeda }}{\longrightarrow}} \mathrm{Mn}(\text { hfacac })_{2}($ tmeda $)$
}

Mn(hfacac)2(tmeda) complex. Following a previously published procedure, ${ }^{2}$ $\mathrm{Mn}(\mathrm{OAc})_{2}\left(\mathrm{H}_{2} \mathrm{O}\right)_{4}(527.3 \mathrm{mg}, 2.2 \mathrm{mmol})$ added to a flame-dried round-bottom flask and DCM (10 mL) and TMEDA (260 $\mu \mathrm{L}, 1.7 \mathrm{mmol})$ were added and the suspension was stirred at room temperature for 10 minutes. 1,1,1,5,5,5-Hexafluoropentane-2,4dione (hfacac) ( $490 \mu \mathrm{L}, 3.4 \mathrm{mmol}$ ) was added to the flask and the flask was equipped with a reflux condenser and placed in an oil bath set to $45^{\circ} \mathrm{C}$ for 1 hour. The solution was collected by filtration under vacuum and the excess $\mathrm{Mn}(\mathrm{OAc})_{2}\left(\mathrm{H}_{2} \mathrm{O}\right)_{4}$ was filtered off. The filtrate was concentrated under reduced pressure, placed under high vacuum and yellow-orange crystals were obtained. The crystals were placed in a Büchner funnel, washed with pentane $(2 \times 10 \mathrm{~mL})$, and allowed to dry under vacuum to yield Mn(hfacac) 2 (tmeda) (798 mg, 63\%).

FTIR (KBr) cm-1: 2623, 1650, 1386, 1254, 1195, 1147, 1024, 947, 796, 763, 741, 664

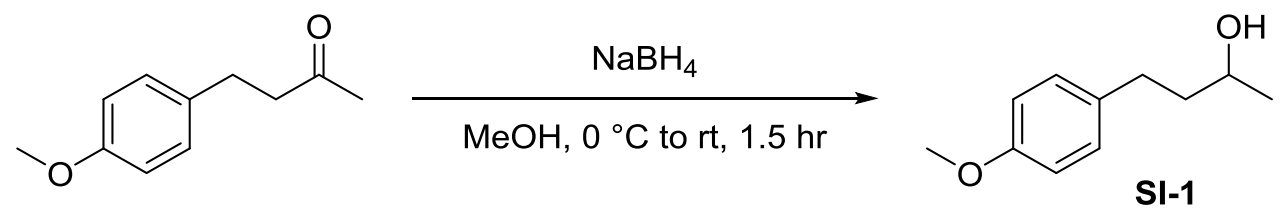

4-(4-Methoxyphenyl)-2-butanol (SI-1). A flame-dried flask equipped with a stir bar was fitted with a rubber septum and backfilled with $\mathrm{N}_{2}$. $\mathrm{NaBH}_{4}(1.59 \mathrm{~g}, 42.1 \mathrm{mmol})$ and anhydrous $\mathrm{MeOH}$ (140 mL, 0.2 M) were added before placing the flask in an ice bath. 4-(4-Methoxyphenyl)-2-butanone (4.8 mL, $28.1 \mathrm{mmol}$ ) was added dropwise at $0{ }^{\circ} \mathrm{C}$ to control the evolution of gas from the reaction flask. Once the addition was complete the ice bath was removed and the reaction was allowed to stir at room temperature for 1.5 hours. The reaction was quenched with saturated $\mathrm{NaHCO}_{3}(50$ $\mathrm{mL})$, diluted with $50 \mathrm{~mL}$ water to dissolve the precipitate, extracted with DCM $(3 \mathrm{x}$ $75 \mathrm{~mL}$ ), dried with $\mathrm{MgSO}_{4}$, and concentrated under reduced pressure to yield SI-1 (5.1g, $>99 \%$ yield) as a colorless oil which matched the literature spectra. ${ }^{3}$ The crude product was used as-is in the subsequent halogenations.

${ }^{1} \mathrm{H}$ NMR $\left(\mathrm{CDCl}_{3}, 400 \mathrm{MHz}\right): \delta 7.10(\mathrm{~d}, \mathrm{~J}=8.6 \mathrm{~Hz}, 2 \mathrm{H}), 6.81(\mathrm{~d}, \mathrm{~J}=8.6 \mathrm{~Hz}, 2 \mathrm{H}), 3.86-$ $3.73(\mathrm{~m}, 4 \mathrm{H}), 2.75-2.53(\mathrm{~m}, 2 \mathrm{H}), 1.81-1.64(\mathrm{~m}, 2 \mathrm{H}), 1.33(\mathrm{~s}, 1 \mathrm{H}), 1.20(\mathrm{~d}, \mathrm{~J}=6.1 \mathrm{~Hz}$, $3 \mathrm{H})$. 
<smiles>COc1ccc(CCC(C)=O)cc1</smiles>

4-(4-Methoxyphenyl)-2-methyl-2-butanol (SI-2). A flame-dried flask equipped with a stir bar was charged with 4-(4-Methoxyphenyl)-2-butanone (891 mg, $850 \mu \mathrm{L}, 5.0$ mmol) and dry THF (25 mL, $0.2 \mathrm{M}$ ) and placed in an ice bath. Methylmagnesium chloride (3M in THF, $2.5 \mathrm{~mL}, 7.5 \mathrm{mmol}$ ) was added dropwise. Once the MeMgCl was added the ice bath was removed and the reaction stirred at room temperature for 2 hours. The reaction was quenched with saturated $\mathrm{NH}_{4} \mathrm{Cl}(25 \mathrm{~mL})$, extracted with $\mathrm{Et}_{2} \mathrm{O}(3 \times 25 \mathrm{~mL})$, dried with $\mathrm{MgSO}_{4}$, and concentrated under reduced pressure. The reaction was purified by silica gel chromatography (30\% EtOAc in hexanes, $\mathrm{R}_{\mathrm{f}}=0.3$ ) to yield SI-2 (895.1 mg, 92\% yield) as a colorless oil which matched the literature spectra. ${ }^{3}$

${ }^{1} \mathrm{H} \mathrm{NMR}\left(\mathrm{CDCl}_{3}, 400 \mathrm{MHz}\right): \delta 7.12(\mathrm{~d}, \mathrm{~J}=8.6 \mathrm{~Hz}, 2 \mathrm{H}), 6.83(\mathrm{~d}, \mathrm{~J}=8.6 \mathrm{~Hz}, 2 \mathrm{H}), 3.79$ (s, $3 \mathrm{H}), 2.69-2.61(\mathrm{~m}, 2 \mathrm{H}), 1.81-1.72(\mathrm{~m}, 2 \mathrm{H}), 1.28(\mathrm{~s}, 6 \mathrm{H}), 1.27(\mathrm{~s}, 1 \mathrm{H})$.

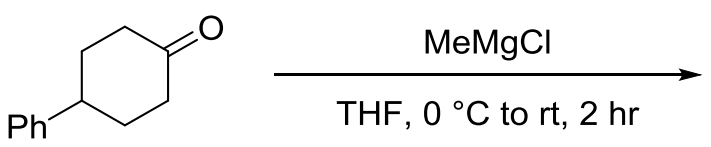<smiles>CC1(O)CCC(c2ccccc2)CC1</smiles>

1-Methyl-4-phenylcyclohexan-1-ol (SI-3). A flame-dried flask equipped with a stir bar was charged with 4-phenylcyclohexan-1-one (500 mg, $2.9 \mathrm{mmol}$ ) and dry THF $(15 \mathrm{~mL}, 0.2 \mathrm{M})$ and placed in an ice bath. Methylmagnesium chloride (2M in THF, 1.7 $\mathrm{mL}, 3.4 \mathrm{mmol}$ ) was added dropwise. Once the $\mathrm{MeMgCl}$ was added the ice bath was removed and the reaction stirred at room temperature for 2 hours. The reaction was quenched with saturated $\mathrm{NH}_{4} \mathrm{Cl}(25 \mathrm{~mL})$, extracted with $\mathrm{Et}_{2} \mathrm{O}(3 \times 25 \mathrm{~mL})$, dried with $\mathrm{MgSO}_{4}$, and concentrated under reduced pressure. The reaction was purified by silica gel chromatography (30\% EtOAc in hexanes, $\left.\mathrm{R}_{\mathrm{f}}=0.3\right)$ to yield an inconsequential 60:40 mixture of diastereomers of SI-3 (313.2 mg and $213.3 \mathrm{mg}$ $96 \%$ combined yield) as white solids which were directly subjected to the halogenation reaction.

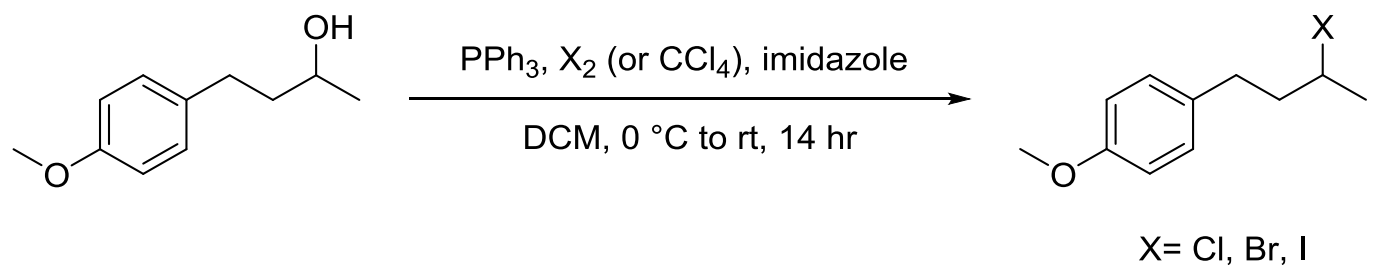

\section{Halogenation of Primary and Secondary Alcohols.}

Chlorides: A flame-dried flask equipped with a stir bar was charged with $\mathrm{PPh}_{3}(2.0$ equiv) and $\mathrm{CCl}_{4}$ (2.1 equiv) under $\mathrm{N}_{2}$. Anhydrous DCM (0.2 M) was added and the 
mixture was placed in an ice bath and stirred for 10 minutes at $0{ }^{\circ} \mathrm{C}$. Alcohol $(1$ equiv), diluted in 5:1 in DCM, was added dropwise at $0{ }^{\circ} \mathrm{C}$. Upon addition of the alcohol, the ice bath was removed and the reaction stirred for 14 hours at room temperature. The reaction was concentrated under reduced pressure and diluted with $25 \%$ EtOAc in hexanes and filtered through a plug of silica. The filtrate was concentrated under reduced pressure and purified by silica gel chromatography. Bromides: A flame-dried flask equipped with a stir bar was charged with $\mathrm{PPh}_{3}(1.2$ equiv) and imidazole (1.2 equiv) under $\mathrm{N}_{2}$. Anhydrous DCM (0.2 M) was added, and the flask was cooled in an ice bath. Bromine (1.2 equiv) was added slowly dropwise at a rate such that the color dissipates, and the mixture was stirred for 10 minutes. Alcohol (1 equiv), diluted in 5:1 in DCM, was added dropwise at $0{ }^{\circ} \mathrm{C}$, and the reaction mixture was stirred at $0{ }^{\circ} \mathrm{C}$ for 1 hour. After one hour, the reaction was allowed to warm to room temperature and stirred for an additional 12 hours. The reaction was concentrated under reduced pressure and diluted with 25\% EtOAc in hexanes and filtered through a plug of silica. The filtrate was concentrated under reduced pressure and purified by silica gel chromatography.

Iodides: A flame-dried flask equipped with a stir bar was charged with $\mathrm{PPh}_{3}(1.2$ equiv), imidazole (1.2 equiv), and I 2 (1.2 equiv) under $\mathrm{N}_{2}$. Anhydrous DCM ( $0.2 \mathrm{M}$ ) was added, and the flask was cooled in an ice bath and the mixture was stirred for 10 minutes. Alcohol (1 equiv), diluted in 5:1 in DCM, was added dropwise at $0{ }^{\circ} \mathrm{C}$, and the reaction mixture was stirred at $0{ }^{\circ} \mathrm{C}$ for 1 hour. After one hour, the reaction was allowed to warm to room temperature and stirred for an additional 12 hours. The reaction was concentrated under reduced pressure and diluted with 25\% EtOAc in hexanes and filtered through a plug of silica. The filtrate was concentrated under reduced pressure and purified by silica gel chromatography.

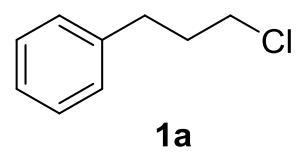

(3-chloropropyl)benzene (1a). 3-phenyl-1-propanol (500 $\mu \mathrm{L}$, $500 \mathrm{mg}, 3.7 \mathrm{mmol}$ ) was treated following the Halogenation of Primary and Secondary Alcohols for chlorides. Silica gel chromatography $\left(10 \%\right.$ EtOAc in hexanes, $\left.\mathrm{R}_{\mathrm{f}}=0.8\right)$ yielded 1a (509.1 mg, 90\% yield) as a colorless oil which matched the literature spectra. ${ }^{4}$

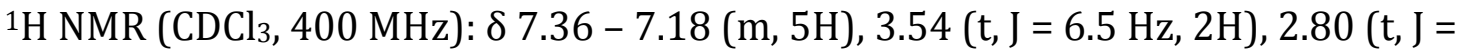
$7.4 \mathrm{~Hz}, 2 \mathrm{H}), 2.15-2.05(\mathrm{~m}, 2 \mathrm{H})$.<smiles>BrCCCc1ccccc1</smiles>

1b

(3-bromopropyl)benzene (1b). 3-phenyl-1-propanol (500 $\mu \mathrm{L}, 500 \mathrm{mg}, 3.7 \mathrm{mmol}$ ) was treated following the Halogenation of Primary and Secondary Alcohols 
bromides. Silica gel chromatography (10\% EtOAc in hexanes, $\left.\mathrm{R}_{\mathrm{f}}=0.8\right)$ yielded $\mathbf{1 b}$ (658.3 mg, 90\% yield) as a colorless oil which matched the literature spectra. ${ }^{4}$

$\left.{ }^{1} \mathrm{H} \mathrm{NMR} \mathrm{(CDCl} 3,400 \mathrm{MHz}\right): \delta 7.36-7.18(\mathrm{~m}, 5 \mathrm{H}), 3.41(\mathrm{t}, \mathrm{J}=6.6 \mathrm{~Hz}, 2 \mathrm{H}), 2.80(\mathrm{t}, \mathrm{J}=$ $7.4 \mathrm{~Hz}, 2 \mathrm{H}), 2.23-2.15(\mathrm{~m}, 2 \mathrm{H})$.<smiles>COc1ccc(CCCl)cc1</smiles>

1-(2-chloroethyl)-4-methoxybenzene (1u). 2-(4-methoxyphenyl)-1-ethanol (787.5 $\mathrm{mg}, 5.2 \mathrm{mmol}$ ) was treated following the Halogenation of Primary and Secondary Alcohols for chlorides. Silica gel chromatography $\left(10 \%\right.$ EtOAc in hexanes, $\left.R_{f}=0.45\right)$ yielded $1 \mathbf{u}(590.7 \mathrm{mg}, 67 \%)$ as a colorless oil which matched the literature spectra. ${ }^{5}$

${ }^{1} \mathrm{H} \mathrm{NMR}\left(\mathrm{CDCl}_{3}, 400 \mathrm{MHz}\right): \delta 7.15(\mathrm{~d}, \mathrm{~J}=8.2 \mathrm{~Hz}, 2 \mathrm{H}), 6.92-6.82(\mathrm{~m}, 2 \mathrm{H}), 3.80(\mathrm{~d}, \mathrm{~J}=$ $1.0 \mathrm{~Hz}, 3 \mathrm{H}), 3.68(\mathrm{t}, \mathrm{J}=7.4 \mathrm{~Hz}, 2 \mathrm{H}), 3.02(\mathrm{t}, \mathrm{J}=7.5 \mathrm{~Hz}, 2 \mathrm{H})$.<smiles>COc1ccc(CCC(C)Cl)cc1</smiles>

1-(3-Chlorobutyl)-4-methoxybenzene (1c). 4-(4-Methoxyphenyl)-2-butanol (SI-1) ( $3.0 \mathrm{~g}, 16.6 \mathrm{mmol}$ ) was treated following the Halogenation of Primary and Secondary Alcohols. Silica gel chromatography $\left(10 \%\right.$ EtOAc in hexanes, $\left.\mathrm{R}_{\mathrm{f}}=0.45\right)$ yielded 1c (3.06g, 92\% yield) as a colorless oil which matched the literature spectra. ${ }^{6}$

${ }^{1} \mathrm{H} \mathrm{NMR}\left(\mathrm{CDCl}_{3}, 400 \mathrm{MHz}\right): \delta 7.11(\mathrm{~d}, \mathrm{~J}=8.6 \mathrm{~Hz}, 2 \mathrm{H}), 6.82(\mathrm{~d}, \mathrm{~J}=8.6 \mathrm{~Hz}, 2 \mathrm{H}), 4.02-$ $3.91(\mathrm{~m}, 1 \mathrm{H}), 3.78(\mathrm{~s}, 3 \mathrm{H}), 2.83-2.61(\mathrm{~m}, 2 \mathrm{H}), 2.04-1.89(\mathrm{~m}, 2 \mathrm{H}), 1.51(\mathrm{~d}, \mathrm{~J}=6.6 \mathrm{~Hz}$, $3 \mathrm{H})$.<smiles>COc1ccc(CCC(C)Br)cc1</smiles>

1-(3-Bromobutyl)-4-methoxybenzene (1d). 4-(4-Methoxyphenyl)-2-butanol (SI-1) ( $4 \mathrm{~g}, 3.8 \mathrm{~mL}, 22.44 \mathrm{mmol}$ ) was treated following the Halogenation of Primary and Secondary Alcohols for bromides. Silica gel chromatography $10 \%$ EtOAc in hexanes, $R_{f}=0.45$ ) yielded $\mathbf{1 d}(4.1 \mathrm{~g}, 75 \%$ yield) as a colorless oil which matched the literature spectra. ${ }^{3}$ 
${ }^{1} \mathrm{H} \mathrm{NMR}\left(\mathrm{CDCl}_{3}, 400 \mathrm{MHz}\right): \delta 7.12(\mathrm{~d}, \mathrm{~J}=8.6 \mathrm{~Hz}, 2 \mathrm{H}), 6.84(\mathrm{~d}, \mathrm{~J}=8.6 \mathrm{~Hz}, 2 \mathrm{H}), 4.07(\mathrm{~m}$, $1 \mathrm{H}), 3.79(\mathrm{~s}, 3 \mathrm{H}), 2.80(\mathrm{~m}, 1 \mathrm{H}), 2.69(\mathrm{~m}, 1 \mathrm{H}), 2.17-1.94(\mathrm{~m}, 2 \mathrm{H}), 1.73(\mathrm{~d}, \mathrm{~J}=6.7 \mathrm{~Hz}$, $3 \mathrm{H})$.<smiles>COc1ccc(CCC(C)I)cc1</smiles>

1-(3-Iodobutyl)-4-methoxybenzene (1e). 4-(4-Methoxyphenyl)-2-butanol (SI-1) (500 mg, $2.77 \mathrm{mmol}$ ) was treated following the Halogenation of Primary and Secondary Alcohols for iodides. Silica gel chromatography (10\% EtOAc in hexanes, $\left.\mathrm{R}_{\mathrm{f}}=0.45\right)$ yielded $1 \mathbf{e}(700 \mathrm{mg}, 87 \%$ yield $)$ as a colorless oil which matched the literature spectra. ${ }^{3}$

${ }^{1} \mathrm{H}$ NMR $\left(\mathrm{CDCl}_{3}, 400 \mathrm{MHz}\right): \delta 7.19-7.09(\mathrm{~m}, 2 \mathrm{H}), 6.88-6.78(\mathrm{~m}, 2 \mathrm{H}), 4.16-4.04(\mathrm{~m}$, $1 \mathrm{H}), 3.79(\mathrm{~s}, 3 \mathrm{H}), 2.86-2.73(\mathrm{~m}, 1 \mathrm{H}), 2.70-2.58(\mathrm{~m}, 1 \mathrm{H}), 2.21-2.03(\mathrm{~m}, 1 \mathrm{H}), 1.95$ $(\mathrm{d}, \mathrm{J}=6.8 \mathrm{~Hz}, 3 \mathrm{H}), 1.90-1.77(\mathrm{~m}, 1 \mathrm{H})$.<smiles>CC1CCC(C(C)(C)C)C(Cl)C1</smiles>

Neomenthyl chloride (1n). (-)-Menthol $(1.0 \mathrm{~g}, 6.4 \mathrm{mmol})$ was treated following the Halogenation of Primary and Secondary Alcohols for chlorides. Silica gel chromatography (10\% EtOAc in hexanes $\left.\mathrm{R}_{\mathrm{f}}=0.8\right)$ yielded $\mathbf{1 n}(437 \mathrm{mg}, 39 \%)$ as a colorless oil which matched the literature spectra. ${ }^{7}$

${ }^{1} \mathrm{H} \mathrm{NMR}\left(\mathrm{CDCl}_{3}, 400 \mathrm{MHz}\right): \delta 4.51(\mathrm{~s}, 1 \mathrm{H}), 2.11-2.01(\mathrm{~m}, 1 \mathrm{H}), 1.98-1.83(\mathrm{~m}, 1 \mathrm{H})$, $1.79-1.67(\mathrm{~m}, 2 \mathrm{H}), 1.64-1.48(\mathrm{~m}, 1 \mathrm{H}), 1.46-1.29(\mathrm{~m}, 2 \mathrm{H}), 1.09-0.99(\mathrm{~m}, 1 \mathrm{H})$, $0.97-0.85(\mathrm{~m}, 10 \mathrm{H})$.

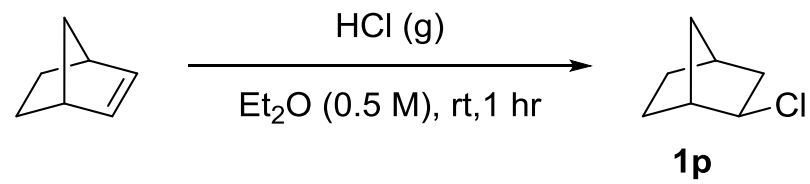

exo-2-Chloronorbornane (1p). In a $50 \mathrm{~mL}$ 2-neck round-bottom flask equipped with a stir bar was added norbornylene $(2.0 \mathrm{~g}, 10.6 \mathrm{mmol})$ and anhydrous $\mathrm{Et}_{2} \mathrm{O}(20 \mathrm{~mL}$, $0.5 \mathrm{M}$ ). A steady stream of $\mathrm{HCl}$ gas was generated by the dropwise addition of conc. $\mathrm{HCl}$ to anhydrous $\mathrm{CaCl}_{2}$ and was bubbled through the norbornylene solution for 15 minutes after which the outlet was sealed, the gas inlet removed, and the solution was allowed to stir under a saturated $\mathrm{HCl}$ atmosphere for an additional 45 minutes. Upon completion the reaction was extracted once each with $20 \mathrm{~mL}$ water, saturated 
$\mathrm{NaHCO}_{3}$, and brine, dried over $\mathrm{MgSO}_{4}$, and concentrated. The resultant oil was dissolved in pentane and filtered through a small pad of $\mathrm{SiO}_{2}$ and concentrated again to yield 1p (1.34g, 48\% yield) as a colorless liquid which matched the literature spectra. $^{8}$

${ }^{1} \mathrm{H} \mathrm{NMR}\left(\mathrm{CDCl}_{3}, 400 \mathrm{MHz}\right): \delta 3.93-3.85(\mathrm{~m}, 1 \mathrm{H}), 2.41(\mathrm{~d}, \mathrm{~J}=4.9 \mathrm{~Hz}, 1 \mathrm{H}), 2.37-2.29$ $(\mathrm{m}, 1 \mathrm{H}), 1.96-1.87(\mathrm{~m}, 1 \mathrm{H}), 1.85-1.74(\mathrm{~m}, 2 \mathrm{H}), 1.68-1.56(\mathrm{~m}, 1 \mathrm{H}), 1.52-1.40(\mathrm{~m}$, $1 \mathrm{H}), 1.28-1.20(\mathrm{~m}, 1 \mathrm{H}), 1.18-1.04(\mathrm{~m}, 2 \mathrm{H})$.

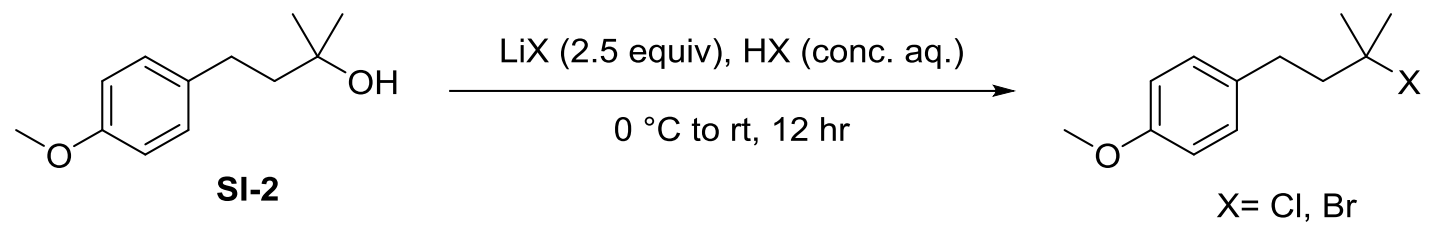

Halogenation of Tertiary Alcohols. A flask was charged with $\mathrm{LiBr}$ or $\mathrm{LiCl}$ (2.5 equiv) dissolved in $\mathrm{HBr}$ ( $48 \%$ aq, $0.5 \mathrm{M}$ relative to substrate) or concentrated $\mathrm{HCl}$ ( $0.5 \mathrm{M}$ relative to substrate), respectively, capped with a rubber septum, and cooled to $0^{\circ} \mathrm{C}$. Alcohol (neat or dissolved in a minimal amount of DCM) was added to the flask, and the reaction was allowed to stir at room temperature for 12 hours. The reaction mixture was extracted with DCM, washed once each with water, saturated $\mathrm{NaHCO}_{3}$, and brine, dried with $\mathrm{MgSO}_{4}$, and concentrated under reduced pressure. Reaction was purified by silica gel chromatography.<smiles>COc1ccc(CCC(C)(C)Cl)cc1</smiles>

1-(3-chloro-3-methylbutyl)-4-methoxybenzene (1f). 4-(4-Methoxyphenyl)-2methyl-2-butanol SI-2 (485 mg, $2.5 \mathrm{mmol}$ ) was treated following the halogenation of tertiary alcohols using $\mathrm{LiCl}$ and concentrated $\mathrm{HCl}$. Silica gel chromatography $(50 \mathrm{~g}$, 2\%-20\% EtOAc in hexanes, 1\%/37 mL, $40 \mathrm{~mL} / \mathrm{min}$ ) yielded 1 f (401.6 mg, 76\% yield) as a colorless oil which matched the literature spectra. ${ }^{3}$

${ }^{1} \mathrm{H} \mathrm{NMR}\left(\mathrm{CDCl}_{3}, 400 \mathrm{MHz}\right): \delta 7.12(\mathrm{~d}, \mathrm{~J}=8.6 \mathrm{~Hz}, 2 \mathrm{H}), 6.84(\mathrm{~d}, \mathrm{~J}=8.6 \mathrm{~Hz}, 2 \mathrm{H}), 3.79(\mathrm{~s}$, $3 \mathrm{H}), 2.82-2.70(\mathrm{~m}, 2 \mathrm{H}), 2.06-1.95(\mathrm{~m}, 2 \mathrm{H}), 1.64(\mathrm{~s}, 6 \mathrm{H})$.<smiles>COc1ccc(CCC(C)(C)Br)cc1</smiles>

1-(3-bromo-3-methylbutyl)-4-methoxybenzene (1g). 4-(4-Methoxyphenyl)-2methyl-2-butanol SI-2 (388 mg, $2.0 \mathrm{mmol}$ ) was treated following Procedure B using $\mathrm{LiBr}$ and $48 \%$ aq. HBr. Silica gel chromatography (50g, 2\%-20\% EtOAc in hexanes, 
1\%/37 mL, $40 \mathrm{~mL} / \mathrm{min}$ ) yielded $1 \mathrm{~g}$ (385 $\mathrm{mg}, 75 \%$ yield) as a colorless oil which matched the literature spectra. ${ }^{3}$

${ }^{1} \mathrm{H} \mathrm{NMR}\left(\mathrm{CDCl}_{3}, 500 \mathrm{MHz}\right): \delta 7.13(\mathrm{~d}, \mathrm{~J}=8.6 \mathrm{~Hz}, 2 \mathrm{H}), 6.84(\mathrm{~d}, \mathrm{~J}=8.6 \mathrm{~Hz}, 2 \mathrm{H}), 3.79(\mathrm{~s}$, $3 \mathrm{H}), 2.83-2.76(\mathrm{~m}, 2 \mathrm{H}), 2.09-2.02(\mathrm{~m}, 2 \mathrm{H}), 1.82(\mathrm{~s}, 6 \mathrm{H})$.

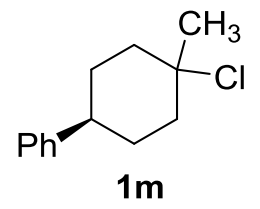

(4-Chloro-4-methylcyclohexyl)benzene (1m). 1-methyl-4-phenylcyclohexan-1-ol SI$3(1.64 \mathrm{~g}, 8.6 \mathrm{mmol})$ was treated following the halogenation of tertiary alcohols B using $\mathrm{LiCl}$ and concentrated $\mathrm{HCl}$. Filtering through a silica plug (eluent: pentanes) yielded $1 \mathrm{~m}$ (771 mg, 43\% yield), an 85:15 mixture of diastereomers, as a colorless liquid.

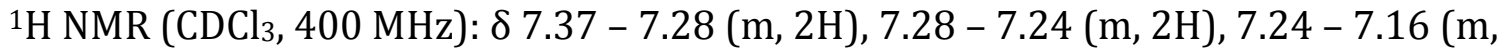
$1 \mathrm{H}), 2.53-2.42(\mathrm{~m}, 1 \mathrm{H}), 2.16-2.07(\mathrm{~m}, 2 \mathrm{H}), 2.05-1.95(\mathrm{~m}, 2 \mathrm{H}), 1.84-1.74(\mathrm{~m}$, $2 \mathrm{H}), 1.72-1.62(\mathrm{~m}, 5 \mathrm{H})$.

${ }^{13} \mathrm{C}$ NMR $\left(\mathrm{CDCl}_{3}, 100 \mathrm{MHz}\right) \delta 146.7,128.3,126.9,126.1,71.5,43.4,41.5,34.2,29.9$. HRMS (EI) Calc. for $\mathrm{C}_{13} \mathrm{H}_{17} \mathrm{Cl}[\mathrm{M}+]$, 208.1013. Found: 208.1017.

FTIR (NaCl) cm-1: 3027, 2933, 2863, 1603, 1493, 1451, 1439, 1126, 699

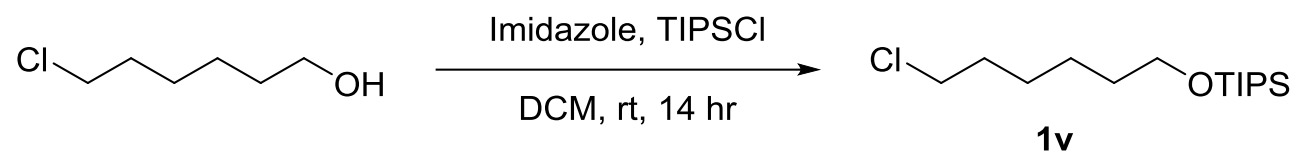

(6-Chlorohexyloxy)triisopropylsilane (1v). A flame-dried flask equipped with a stir bar was charged with 6-chloro-1-hexanol $(1.0 \mathrm{~g}, 980 \mu \mathrm{L}, 7.3 \mathrm{mmol})$ and DCM $(0.1$ M). Imidozole ( $996.6 \mathrm{mg}, 14.6 \mathrm{mmol}$ ) and chlorotriisopropylsilane $(3.1 \mathrm{~mL}, 14.6$ $\mathrm{mmol}$ ), and the reaction was stirred for $14 \mathrm{~h}$ at room temperature. Saturated aq. $\mathrm{NaHCO}_{3}$ was added and the product was extracted three times with $\mathrm{Et}_{2} \mathrm{O}$. The combined organic layers were dried with $\mathrm{MgSO}_{4}$, filtered, and concentrated under reduced pressure and the residue was purified by flash column chromatography $\left(10 \%\right.$ EtOAc in hexanes $\left.\mathrm{R}_{\mathrm{f}}=0.9\right)$ to furnish $\mathbf{1 v}(1.63 \mathrm{~g}, 76 \%)$ as a colorless oil which matched the literature spectra. ${ }^{9}$

${ }^{1} \mathrm{H} \mathrm{NMR}\left(\mathrm{CDCl}_{3}, 400 \mathrm{MHz}\right): \delta 3.68(\mathrm{t}, \mathrm{J}=6.4 \mathrm{~Hz}, 2 \mathrm{H}), 3.53(\mathrm{t}, \mathrm{J}=6.7 \mathrm{~Hz}, 2 \mathrm{H}), 1.84-$ $1.72(\mathrm{~m}, 2 \mathrm{H}), 1.55(\mathrm{p}, \mathrm{J}=6.6,6.2 \mathrm{~Hz}, 2 \mathrm{H}), 1.50-1.31(\mathrm{~m}, 4 \mathrm{H}), 1.14-0.98(\mathrm{~m}, 21 \mathrm{H})$. 


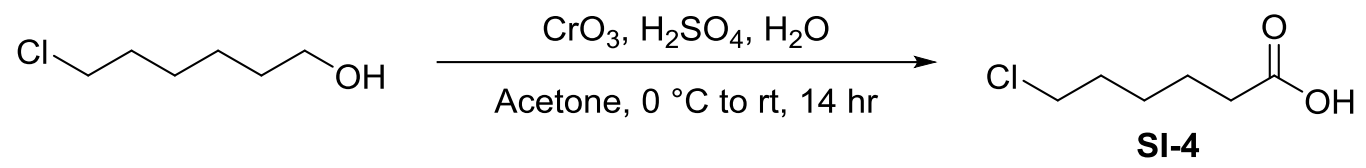

6-Chlorohexanoic acid (SI-4). To a $100 \mathrm{~mL}$ round-bottom flask equipped with a stir bar was added reagent grade acetone $(40 \mathrm{~mL}, 0.2 \mathrm{M})$ and 6-Chloro-1-hexanol $(1.0 \mathrm{~g}$, $970 \mu \mathrm{L}, 7.3 \mathrm{mmol}$ ) and the flask was placed in an ice bath. $\mathrm{CrO}_{3}(880 \mathrm{mg}, 8.8 \mathrm{mmol}$ ) was added to a $20 \mathrm{~mL}$ vial followed by $2.5 \mathrm{~mL}$ deionized $\mathrm{H}_{2} \mathrm{O}$ and $750 \mu \mathrm{L}$ concentrated $\mathrm{H}_{2} \mathrm{SO}_{4}$. The resulting bright orange solution was added via syringe to the flask under vigorous stirring. Once the addition was complete, the ice bath was removed and the reaction was stirred at room temperature for 1 hour. $500 \mu \mathrm{L}$ of isopropanol was added and stirred for an additional 20 minutes. The reaction mixture was decanted and filtered through a pad of silica and the reaction flask and silica were washed twice with two $25 \mathrm{~mL}$ portions of acetone. The combined washings were concentrated under reduced pressure, redissolved in $50 \mathrm{~mL} \mathrm{Et}_{2} \mathrm{O}$, and added to a separatory funnel. The organic layer was washed once each with 25 $\mathrm{mL} \mathrm{NaHSO}_{3}$ and water and the washings were discarded. Then, the organic layer was extracted saturated $\mathrm{NaHCO}_{3}(2 \times 25 \mathrm{~mL})$ and water $(15 \mathrm{~mL})$ and the combined aqueous washings were set aside. $\mathrm{HCl}(1 \mathrm{M})$ was added slowly to the aqueous solution until the $\mathrm{pH}$ was under 4 and the solution was extracted with $\mathrm{Et}_{2} \mathrm{O}(3 \times 25$ $\mathrm{mL}$ ), the combined organics dried over $\mathrm{MgSO}_{4}$, filtered, and concentrated under reduced pressure to give $\mathbf{S I - 4}$ (939 $\mathrm{mg}, 85 \%$ ) as a colorless solid which matched the literature spectrum. ${ }^{10}$

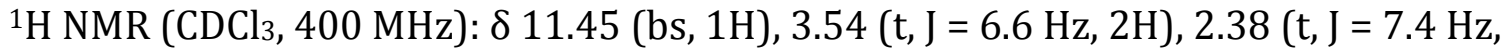
$2 \mathrm{H}), 1.80(\mathrm{~m}, 2 \mathrm{H}), 1.72-1.62(\mathrm{~m}, 2 \mathrm{H}), 1.55-1.45(\mathrm{~m}, 2 \mathrm{H})$.

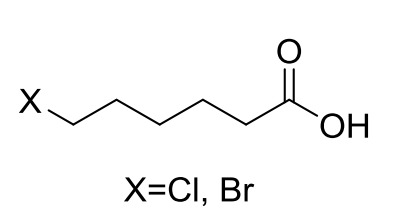

1. $(\mathrm{COCl})_{2}$, DMF $(5 \%)$
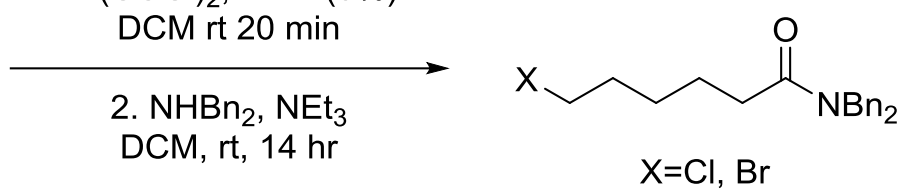

Amidation of carboxylic acids. To a flame-dried round-bottom flask equipped with a stir bar was added 6-halohexanoic acid, DMF ( $5 \mathrm{~mol} \%$ ), and DCM (0.5 M). Oxalyl chloride (1.5 equiv) was added dropwise over 3 minutes. The reaction was stirred at room temperature until bubbling ceased (approx. 15-20 $\mathrm{min}$ ) and the reaction was concentrated by rotary evaporation. The crude reaction product was redissolved in DCM $(0.5 \mathrm{M})$ and stirred under $\mathrm{N}_{2}$. Dibenzylamine (1.1 equiv) was added in a single portion followed by $\mathrm{NEt}_{3}$ (2.0 equiv) dropwise over one minute and the reaction was stired for an additional 14 hours. The reaction mixture was then further diluted with DCM and aqueous $1 \mathrm{M} \mathrm{HCl}$ was added. The organic layer was removed, and the aqueous layer was then extracted with 3 times with DCM. The combined organic layers were washed with saturated aq. $\mathrm{NaHCO}_{3}$, brine, dried with $\mathrm{MgSO}_{4}$ and concentrated by rotary evaporation. The reaction was purified by silica gel chromatography to furnish the product. 
<smiles>O=C(CCCCCCl)Nc1ccccc1</smiles>

$N, N$-Dibenzyl-6-chlorohexanamide (1i). 6-Chlorohexanoic acid SI-4 (350 mg, 2.3 $\mathrm{mmol}$ ) was treated following the procedure for the amidation of carboxylic acids. Silica gel chromatography $\left(25 \mathrm{~g} \mathrm{SiO}_{2}, 5 \%-40 \%\right.$ EtOAc in hexanes, 1\%/9mL, 25 $\mathrm{mL} / \mathrm{min}$ ) yielded $1 \mathbf{i}(581 \mathrm{mg}, 76 \%$ yield) as a white solid.

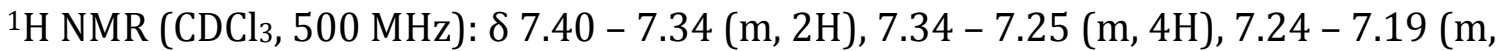
$2 \mathrm{H}), 7.17-7.13(\mathrm{~m}, 2 \mathrm{H}), 4.62(\mathrm{~s}, 2 \mathrm{H}), 4.45(\mathrm{~s}, 2 \mathrm{H}), 3.53(\mathrm{t}, \mathrm{J}=6.7 \mathrm{~Hz}, 2 \mathrm{H}), 2.43(\mathrm{t}, \mathrm{J}=$ $7.4 \mathrm{~Hz}, 2 \mathrm{H}), 1.82-1.70(\mathrm{~m}, 4 \mathrm{H}), 1.54-1.43(\mathrm{~m}, 2 \mathrm{H})$.

${ }^{13} \mathrm{C} \mathrm{NMR}\left(\mathrm{CDCl}_{3}, 125 \mathrm{MHz}\right): \delta 173.4,137.6,136.7,129.1,128.7,128.4,127.8,127.5$, $126.4,50.1,48.4,45.0,33.1,32.6,26.8,24.7$.

HRMS (EI) Calc. for $\mathrm{C}_{20} \mathrm{H}_{24} \mathrm{ClNO}$ [M+], 329.1546. Found: 329.1537.

FTIR (NaCl) cm-1: 3030, 2983, 2866, 1648, 1495, 1452, 1212, 700<smiles>O=C(CCCCCBr)NCCCCBr</smiles>

$1 \mathrm{j}$

$N, N$-Dibenzyl-6-bromohexanamide (1j). 6-Bromohexanoic acid (500 mg, 2.56 mmol) was treated following the procedure for the amidation of carboxylic acids. Silica gel chromatography $\left(25 \mathrm{~g} \mathrm{SiO}_{2}, 5 \%-40 \%\right.$ EtOAc in hexanes, 1\%/9mL, 25 $\mathrm{mL} / \mathrm{min}$ ) yielded $\mathbf{1 j}$ (851 $\mathrm{mg}, 89 \%$ yield) as a colorless oil.

${ }^{1} \mathrm{H} \mathrm{NMR}\left(\mathrm{CDCl}_{3}, 400 \mathrm{MHz}\right): \delta 7.42-7.26(\mathrm{~m}, 6 \mathrm{H}), 7.24-7.20(\mathrm{~m}, 2 \mathrm{H}), 7.18-7.12(\mathrm{~m}$, $2 \mathrm{H}), 4.62(\mathrm{~s}, 2 \mathrm{H}), 4.45(\mathrm{~s}, 2 \mathrm{H}), 3.40(\mathrm{t}, \mathrm{J}=6.8 \mathrm{~Hz}, 2 \mathrm{H}), 2.43(\mathrm{t}, \mathrm{J}=7.4 \mathrm{~Hz}, 2 \mathrm{H}), 1.93-$ $1.81(\mathrm{~m}, 2 \mathrm{H}), 1.81-1.68(\mathrm{~m}, 2 \mathrm{H}), 1.54-1.42(\mathrm{~m}, 2 \mathrm{H})$.

${ }^{13} \mathrm{C} \mathrm{NMR}\left(\mathrm{CDCl}_{3}, 100 \mathrm{MHz}\right): \delta 173.3,137.6,136.7,129.1,128.7,128.4,127.8,127.5$, 126.4, 50.0, 48.4, 33.8, 33.1, 32.7, 28.1, 24.6.

HRMS (EI) Calc. for $\mathrm{C}_{20} \mathrm{H}_{24} \mathrm{BrNO}$ [M+], 373.1041. Found: 373.1042 .

FTIR (NaCl) cm-1: 3029, 2934, 2865, 1647, 1495, 1452, 1210, 700

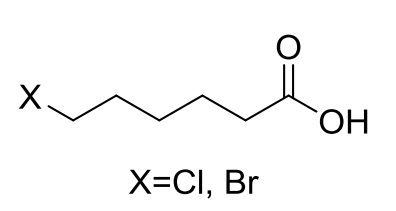

$$
\text { 1. }(\mathrm{COCl})_{2} \text {, DMF }(5 \%)
$$
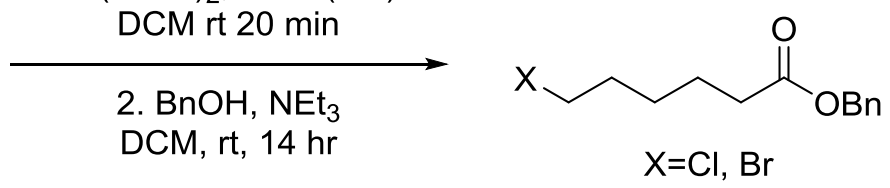

Esterification of carboxylic acids. To a flame-dried round-bottom flask equipped with a stir bar was added 6-halohexanoic acid, DMF (5 mol \%), and DCM (0.5 M). Oxalyl chloride ( 1.5 equiv) was added dropwise over 3 minutes. The reaction was stirred at room temperature until bubbling ceased (approx. 15-20 min) and the 
reaction was concentrated by rotary evaporation. The crude reaction product was redissolved in DCM (0.5 M) and stirred under $\mathrm{N}_{2}$. Benzyl alcohol (1.1 equiv) was added in a single portion followed by $\mathrm{NEt}_{3}$ (2.0 equiv) dropwise over one minute and the reaction was stired for an additional 14 hours. The reaction mixture was then further diluted with DCM and aqueous $1 \mathrm{M} \mathrm{HCl}$ was added. The organic layer was removed, and the aqueous layer was then extracted with 3 times with DCM. The combined organic layers were washed with saturated aq. $\mathrm{NaHCO}_{3}$, brine, dried with $\mathrm{MgSO}_{4}$ and concentrated by rotary evaporation. The reaction was purified by silica gel chromatography to furnish the product.<smiles>O=C(CCCCCCl)O[Mg]</smiles>

Benzyl 6-chlorohexanoate (1k). 6-Chlorohexanoic acid SI-4 (350 mg, $2.3 \mathrm{mmol}$ ) was treated following the procedure for the esterification of carboxylic acids. Silica gel chromatography $\left(25 \mathrm{~g} \mathrm{SiO}_{2}, 5 \%-35 \%\right.$ EtOAc in hexanes, $1 \% / 15 \mathrm{~mL}, 25 \mathrm{~mL} / \mathrm{min}$ ) yielded 1k (425mg, 77\% yield) as a colorless oil which matched the reported spectra. ${ }^{11}$

${ }^{1} \mathrm{H}$ NMR ( $\left.\mathrm{CDCl}_{3}, 400 \mathrm{MHz}\right): \delta 7.41-7.30(\mathrm{~m}, 5 \mathrm{H}), 5.12(\mathrm{~s}, 2 \mathrm{H}), 3.52(\mathrm{t}, \mathrm{J}=6.7 \mathrm{~Hz}, 2 \mathrm{H})$, $2.38(\mathrm{t}, \mathrm{J}=7.4 \mathrm{~Hz}, 2 \mathrm{H}), 1.84-1.74(\mathrm{~m}, 2 \mathrm{H}), 1.73-1.63(\mathrm{~m}, 2 \mathrm{H}), 1.53-1.42(\mathrm{~m}, 2 \mathrm{H})$.<smiles>CC(CCCBr)CCC(=O)OCc1ccccc1</smiles>

Benzyl 6-bromohexanoate (11). 6-Bromohexanoic acid (500 mg, $2.56 \mathrm{mmol}$ ) was treated following the procedure for the esterification of carboxylic acids. Silica gel chromatography (25g SiO 2 , 5\%-35\% EtOAc in hexanes, 1\%/15mL, $25 \mathrm{~mL} / \mathrm{min}$ ) yielded $\mathbf{1 l}$ (525 mg, 72\% yield) as a colorless oil which matched the reported spectra. $^{12}$

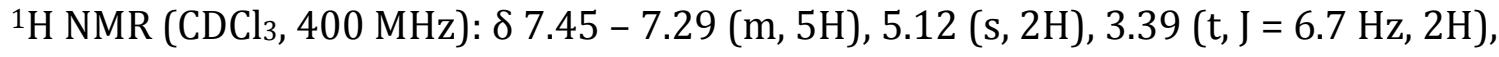
$2.38(\mathrm{t}, \mathrm{J}=7.4 \mathrm{~Hz}, 2 \mathrm{H}), 1.92-1.82(\mathrm{~m}, 2 \mathrm{H}), 1.73-1.63(\mathrm{~m}, 2 \mathrm{H}), 1.53-1.42(\mathrm{~m}, 2 \mathrm{H})$.

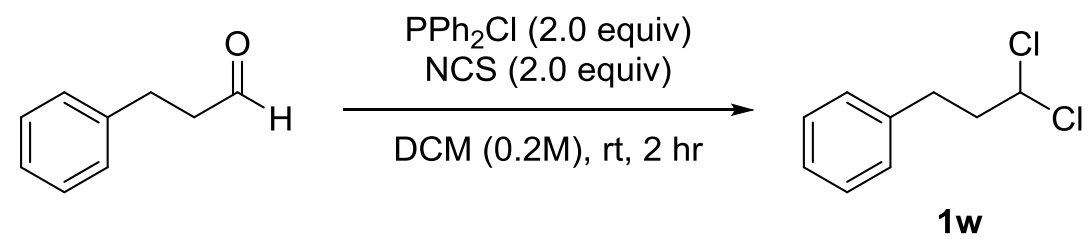

(3,3-Dichloropropyl)benzene (1w). A flame-dried flask was charged with $N$ chlorosuccinamide ( $995 \mathrm{mg}, 7.45 \mathrm{mmol}$ ) and DCM (15 mL, 0.2M). Chloro diphenylphosphine $(1.35 \mathrm{~mL}, 7.45 \mathrm{mmol})$ was added dropwise at room temperature followed by hydrocinnamaldehyde ( $500 \mathrm{mg}, 490 \mu \mathrm{L}, 3.73 \mathrm{mmol}$ ). The stirring was 
continued until TLC showed the completion of the reaction ( $2 \mathrm{~h}$ ). The solvent was then removed under reduced pressure and the reaction was filtered through a silica plug with hexanes. The filtrate was concentrated and purified on silica gel $(100 \%$ hexanes, $\mathrm{R}_{\mathrm{f}}=0.6$ ) to furnish $\mathbf{1} \mathbf{w}$ as a colorless liquid (180.2 $\mathrm{mg}, 26 \%$ yield) which matched the literature spectrum. ${ }^{13}$

${ }^{1} \mathrm{H} \mathrm{NMR}\left(\mathrm{CDCl}_{3}, 400 \mathrm{MHz}\right): \delta 7.33(\mathrm{t}, \mathrm{J}=7.5 \mathrm{~Hz}, 2 \mathrm{H}), 7.23(\mathrm{dd}, \mathrm{J}=14.3,7.0 \mathrm{~Hz}, 3 \mathrm{H})$, $5.67(\mathrm{t}, \mathrm{J}=6.2 \mathrm{~Hz}, 1 \mathrm{H}), 2.89(\mathrm{t}, \mathrm{J}=7.5 \mathrm{~Hz}, 2 \mathrm{H}), 2.57-2.45(\mathrm{~m}, 2 \mathrm{H})$.<smiles>O=CCCc1ccccc1</smiles>
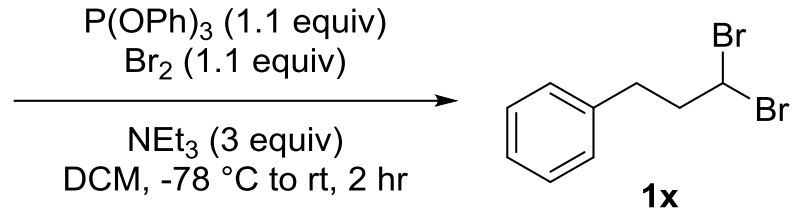

(3,3-Dibromopropyl)benzene (1x). A flame-dried round bottom flask was charged with triphenyl phosphite $(1.15 \mathrm{~mL}, 4.4 \mathrm{mmol})$ and anhydrous DCM $(\mathrm{x} \mathrm{mL})$ at $-78{ }^{\circ} \mathrm{C}$ under $\mathrm{N}_{2}$. Bromine ( $\left.225 \mu \mathrm{L}, 4.4 \mathrm{mmol}\right)$ was added dropwise. Triethylamine $(1.7 \mathrm{~mL}$, $12 \mathrm{mmol}$ ) and hydrocinnamaldehyde (536 mg, $525 \mu \mathrm{L}, 4 \mathrm{mmol}$ ) were added at -78 ${ }^{\circ} \mathrm{C}$. The reaction mixture was allowed to warm to room temperature and stirred for 2 hours. Upon completion, the solvent was evaporated in vacuo and the crude reaction mixture was purified on silica gel $\left(100 \%\right.$ hexanes, $\left.\mathrm{R}_{\mathrm{f}}=0.6\right)$ to afford $\mathbf{1 x}$ (581 mg, 52\%) as a light yellow oil which matched the literature spectrum. ${ }^{14}$

${ }^{1} \mathrm{H} \mathrm{NMR}\left(\mathrm{CDCl}_{3}, 500 \mathrm{MHz}\right): \delta 7.34(\mathrm{t}, \mathrm{J}=7.5 \mathrm{~Hz}, 2 \mathrm{H}), 7.31-7.16(\mathrm{~m}, 3 \mathrm{H}), 5.62(\mathrm{t}, \mathrm{J}=$ $6.3 \mathrm{~Hz}, 1 \mathrm{H}), 2.89(\mathrm{t}, \mathrm{J}=7.4 \mathrm{~Hz}, 2 \mathrm{H}), 2.76-2.70(\mathrm{~m}, 2 \mathrm{H})$.
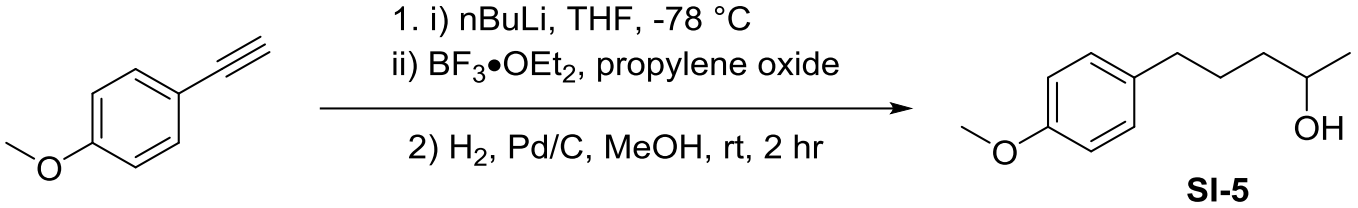

5-(4-methoxyphenyl)pentan-2-ol (SI-5). A flame-dried round-bottom flask equipped with a stir bar was charged with 4-ethynylanisole $(250 \mathrm{mg}, 1.9 \mathrm{mmol})$, dry THF (10 mL, $0.2 \mathrm{mmol}$ ), and cooled to $-78^{\circ} \mathrm{C}$. $n$-BuLi $(2.5 \mathrm{M}$ in hexanes, $1.7 \mathrm{~mL}, 4.2$ $\mathrm{mmol}$ ) was added dropwise over 10 minutes and the reaction was allowed to stir at $-78^{\circ} \mathrm{C}$ for 30 minutes. Propylene oxide $(320 \mu \mathrm{L}, 4.5 \mathrm{mmol})$ was added followed by $\mathrm{BF}_{3} \bullet \mathrm{OEt}_{2}(560 \mu \mathrm{L}, 4.5 \mathrm{mmol})$ and allowed to stir for an additional 3 hours. The reaction was then allowed to warm to $0{ }^{\circ} \mathrm{C}$ and was quenched with $10 \mathrm{~mL}$ saturated $\mathrm{NaHCO}_{3}$, extracted with $\mathrm{Et}_{2} \mathrm{O}(3 \times 10 \mathrm{~mL})$, dried over $\mathrm{MgSO}_{4}$, and concentrated under reduced pressure. The crude mixture was then redissolved in dry $\mathrm{MeOH}(4 \mathrm{~mL}, 0.5$ M) and added to a flame dried round bottom flask equipped with a stir bar. Pd/C (10 $\mathrm{mg}, 10 \%$ ) was added, the flask was flushed with $\mathrm{H}_{2}$ and stirred at room temperature under an $\mathrm{H}_{2}$ atmosphere (1 atm). After 2 hours the reaction mixture was flushed through a plug of silica, washed with $\mathrm{Et}_{2} \mathrm{O}$, and concentrated under reduced 
pressure to furnish SI-5 as a colorless oil (181 $\mathrm{mg}$, 45\% yield) which matched the literature spectra. ${ }^{15}$

${ }^{1} \mathrm{H} \mathrm{NMR}\left(\mathrm{CDCl}_{3}, 400 \mathrm{MHz}\right): \delta 7.10(\mathrm{~d}, \mathrm{~J}=8.6 \mathrm{~Hz}, 2 \mathrm{H}), 6.83(\mathrm{~d}, \mathrm{~J}=8.6 \mathrm{~Hz}, 2 \mathrm{H}), 3.79(\mathrm{~s}$, $3 \mathrm{H}), 2.58(\mathrm{t}, \mathrm{J}=7.6 \mathrm{~Hz}, 2 \mathrm{H}), 1.80-1.56(\mathrm{~m}, 3 \mathrm{H}), 1.53-1.41(\mathrm{~m}, 2 \mathrm{H}), 1.34(\mathrm{~d}, \mathrm{~J}=5.5$ $\mathrm{Hz}, 1 \mathrm{H}), 1.18(\mathrm{~d}, \mathrm{~J}=6.2 \mathrm{~Hz}, 3 \mathrm{H})$.<smiles>COc1ccc(CCC[C@H](C)O)cc1</smiles>

(S)-SI-4

5-(4-methoxyphenyl)pentan-2-ol ((S)-SI-5). 4-Ethynylanisole (500 mg, $3.8 \mathrm{mmol}$ ) was treated following the procedure for $\mathbf{S I - 5}$ using $(S)$-propylene oxide to yield $(\boldsymbol{S})$ SI-5 as a colorless oil (136 mg, 18\% yield). Enantiomeric excess of the product was determined to be $>99 \%$ ee by chiral stationary phase HPLC analysis (Cellulose-1 ( $\Phi 250 \mathrm{~mm} \times 4.60 \mathrm{~mm}$ ), 2-propanol $/ \mathrm{n}$-hexane $=1 / 99$, flow rate $0.75 \mathrm{~mL} / \mathrm{min}$, detection at $280 \mathrm{~nm}, \mathrm{tR}=32.3 \mathrm{~min}, 37.6 \mathrm{~min}$ ).

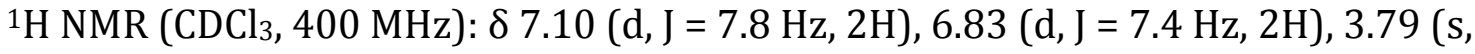
$3 \mathrm{H}), 2.58(\mathrm{t}, \mathrm{J}=7.6 \mathrm{~Hz}, 2 \mathrm{H}), 1.79-1.55(\mathrm{~m}, 3 \mathrm{H}), 1.49(\mathrm{~m}, 2 \mathrm{H}), 1.37(\mathrm{~s}, 1 \mathrm{H}), 1.18(\mathrm{~d}, \mathrm{~J}=$ $6.2,3 \mathrm{H})$.<smiles>COc1ccc(CCCC(C)O)cc1</smiles>

SI-5

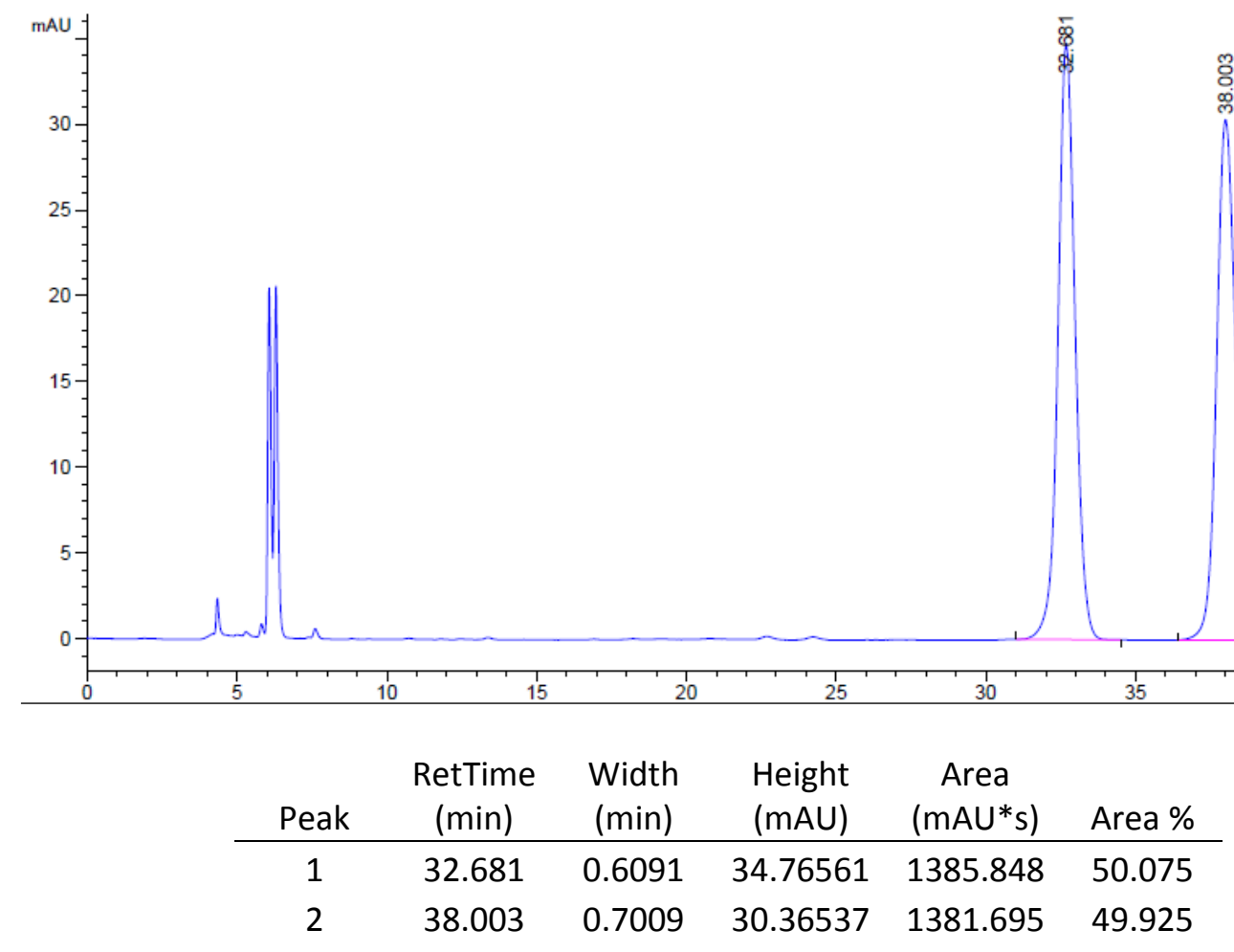


<smiles>COc1ccc(CCC[C@@H](C)O)cc1</smiles>

(S)-SI-5

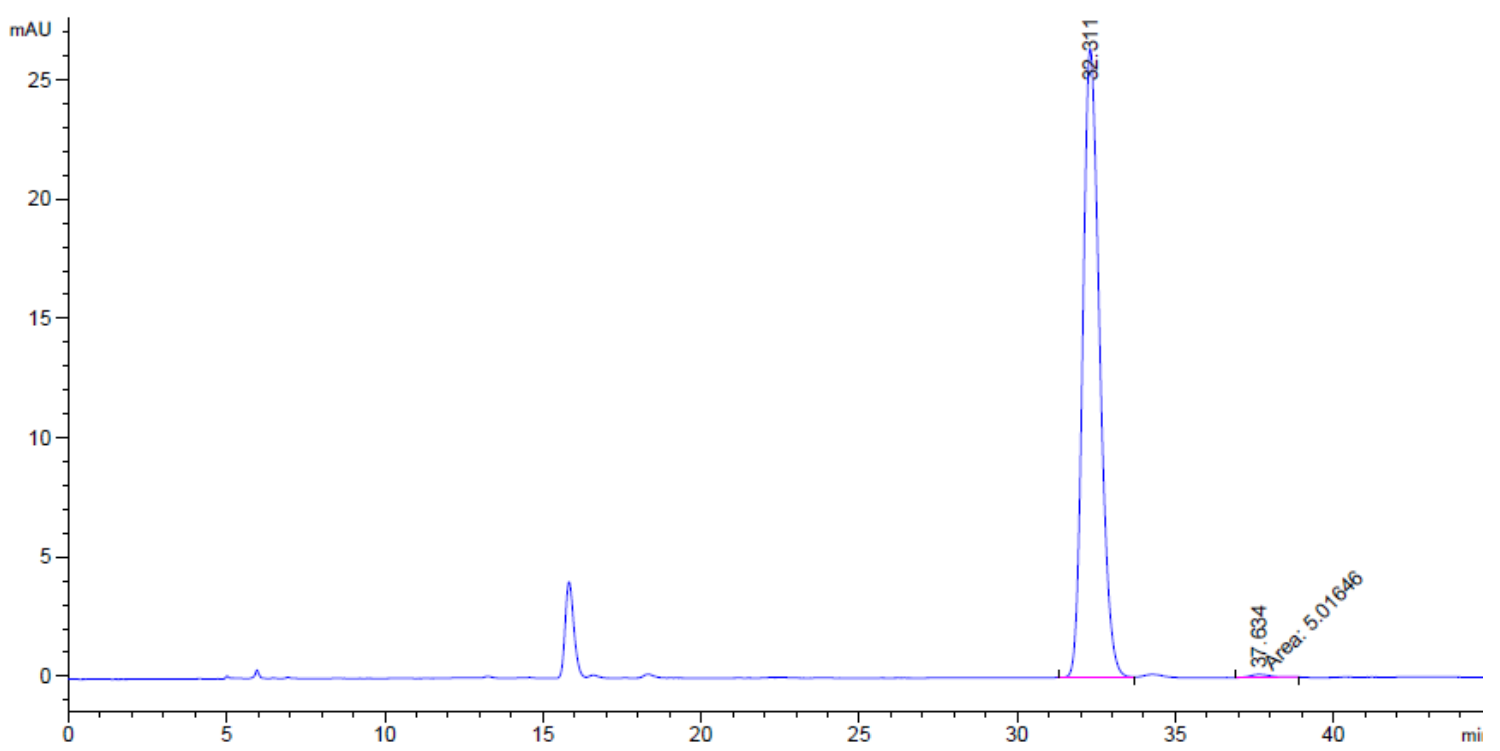

\begin{tabular}{cccccc} 
Peak & $\begin{array}{c}\text { RetTime } \\
(\mathrm{min})\end{array}$ & $\begin{array}{c}\text { Width } \\
(\mathrm{min})\end{array}$ & $\begin{array}{c}\text { Height } \\
(\mathrm{mAU})\end{array}$ & $\begin{array}{c}\text { Area } \\
(\mathrm{mAU} \text { *s) }\end{array}$ & Area \% \\
\hline 1 & 32.311 & 0.5718 & 26.33693 & 974.7455 & 99.488 \\
2 & 37.634 & 0.6794 & 0.123052 & 5.01646 & 0.512
\end{tabular}<smiles>COc1ccc(CCCC(C)Cl)cc1</smiles>

1-(4-chloropentyl)-4-methoxybenzene (SI-6). 5-(4-methoxyphenyl)pentan-2-ol (SI5) (181 mg, $0.9 \mathrm{mmol}$ ) was treated following the Halogenation of Primary and Secondary Alcohols for chlorides with the following modifications: $\mathrm{PPh}_{3}(268.8 \mathrm{mg}$, 1.1 equiv) and $\mathrm{CCl}_{4}(300 \mu \mathrm{L}, 3.3$ equiv) were used in the reaction.. Silica gel chromatography $\left(10 \%\right.$ EtOAc in hexanes $\left.\mathrm{R}_{\mathrm{f}}=0.45\right)$ yielded rac-SI-6 $(105.5 \mathrm{mg}$, $53 \%$ ) as a colorless oil.

${ }^{1} \mathrm{H} \mathrm{NMR}\left(\mathrm{CDCl}_{3}, 400 \mathrm{MHz}\right): \delta 7.10(\mathrm{~d}, \mathrm{~J}=8.2 \mathrm{~Hz}, 2 \mathrm{H}), 6.83(\mathrm{~d}, \mathrm{~J}=8.4 \mathrm{~Hz}, 2 \mathrm{H}), 4.11-$ $3.99(\mathrm{~m}, 1 \mathrm{H}), 3.79(\mathrm{~s}, 3 \mathrm{H}), 2.67-2.50(\mathrm{~m}, 2 \mathrm{H}), 1.86-1.63(\mathrm{~m}, 4 \mathrm{H}), 1.50(\mathrm{~d}, \mathrm{~J}=6.5 \mathrm{~Hz}$, $3 \mathrm{H})$.

${ }^{13} \mathrm{C} \mathrm{NMR}\left(\mathrm{CDCl}_{3}, 100 \mathrm{MHz}\right): \delta 157.9,134.2,129.4,113.9,58.8,55.4,39.9,34.5,28.8$, 25.5 .

HRMS (CI) Calc. for $\mathrm{C}_{12} \mathrm{H}_{17} \mathrm{ClO}$ [M+], 212.0962. Found: 212.0963.

FTIR (NaCl) cm-1: 2932, 2859, 1513, 1246, 1037 
<smiles>COc1ccc(CCCC(C)Cl)cc1</smiles>

$(R)-\mathrm{SI}-6$

(R)-1-(4-chloropentyl)-4-methoxybenzene ((R)-SI-6). (S)-5-(4methoxyphenyl)pentan-2-ol ((S)-SI-5) (136 $\mathrm{mg}, 0.7 \mathrm{mmol})$ was treated following the Halogenation of Primary and Secondary Alcohols for chlorides. Silica gel chromatography $\left(10 \%\right.$ EtOAc in hexanes $\left.\mathrm{R}_{\mathrm{f}}=0.45\right)$ yielded $(\boldsymbol{R})$-SI-6 $(121.2 \mathrm{mg}$, $81 \%$ ) as a colorless oil which matched the NMR spectra for rac-SI-6.

${ }^{1} \mathrm{H} \mathrm{NMR}\left(\mathrm{CDCl}_{3}, 400 \mathrm{MHz}\right): \delta 7.13-7.03(\mathrm{~m}, 2 \mathrm{H}), 6.86-6.77(\mathrm{~m}, 2 \mathrm{H}), 4.02(\mathrm{~h}, \mathrm{~J}=6.4$ $\mathrm{Hz}, 1 \mathrm{H}), 3.78(\mathrm{~s}, 3 \mathrm{H}), 2.65-2.48(\mathrm{~m}, 2 \mathrm{H}), 1.90-1.59(\mathrm{~m}, 4 \mathrm{H}), 1.48(\mathrm{~d}, \mathrm{~J}=6.6 \mathrm{~Hz}, 3 \mathrm{H})$. ${ }^{13} \mathrm{C}$ NMR $\left(\mathrm{CDCl}_{3}, 100 \mathrm{MHz}\right): \delta 157.9,134.2,129.4,113.9,58.8,55.4,39.9,34.5,28.8$, 25.5 .<smiles>COc1ccc(CCCC(C)Cl)cc1</smiles>

Determination of ee of $(\boldsymbol{R})$-SI-6. A flame-dried round-bottom flask equipped with a stir bar was placed under $\mathrm{N}_{2}$, charged with (R)-SI-6 (10 mg, $\left.0.05 \mathrm{mmol}\right)$ and DCM (1 $\mathrm{mL}$ ) and cooled to $-78{ }^{\circ} \mathrm{C}$. $\mathrm{BBr}_{3}(1 \mathrm{M}$ in DCM, $55 \mu \mathrm{L})$ was added and the solution was allowed to stir for 3 hours. The reaction was quenched with $1 \mathrm{M} \mathrm{HCl}(1 \mathrm{~mL})$, extracted with $\mathrm{Et}_{2} \mathrm{O}(2 \times 5 \mathrm{~mL})$ and washed with $\mathrm{H}_{2} \mathrm{O}(3 \times 5 \mathrm{~mL})$. The organic layer was dried over $\mathrm{MgSO}_{4}$, concentrated under reduced pressure, and purified by silica gel chromatography $\left(10 \%\right.$ EtOAc in hexanes $\left.\mathrm{R}_{\mathrm{f}}=0.2\right)$ to afford the product as a pale yellow oil ( $7.5 \mathrm{mg}, 81 \%$ yield). Enantiomeric excess of the product was determined by chiral stationary phase HPLC analysis (Cellulose-2 ( $\$ 250 \mathrm{~mm} \times 4.60 \mathrm{~mm}$ ), 2propanol $/ \mathrm{n}$-hexane $=1 / 99$, flow rate $0.75 \mathrm{~mL} / \mathrm{min}$, detection at $280 \mathrm{~nm}, \mathrm{tR}=35.3$ $\min , 37.1 \mathrm{~min}$ ). 
<smiles>CC(Cl)CCCc1ccc(O)cc1</smiles>

From rac-SI-6

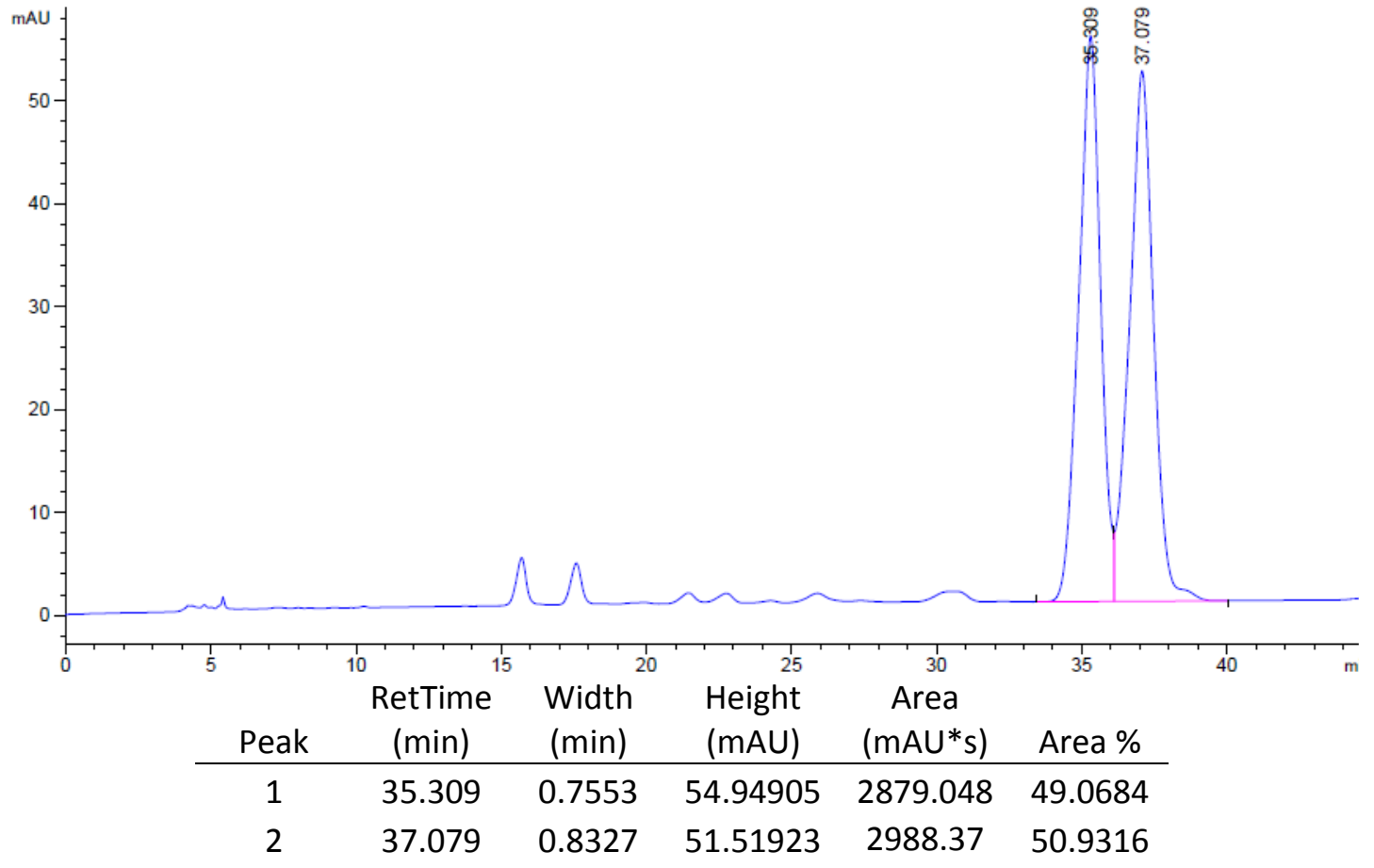


<smiles>CC(Cl)CCCc1ccc(O)cc1</smiles>

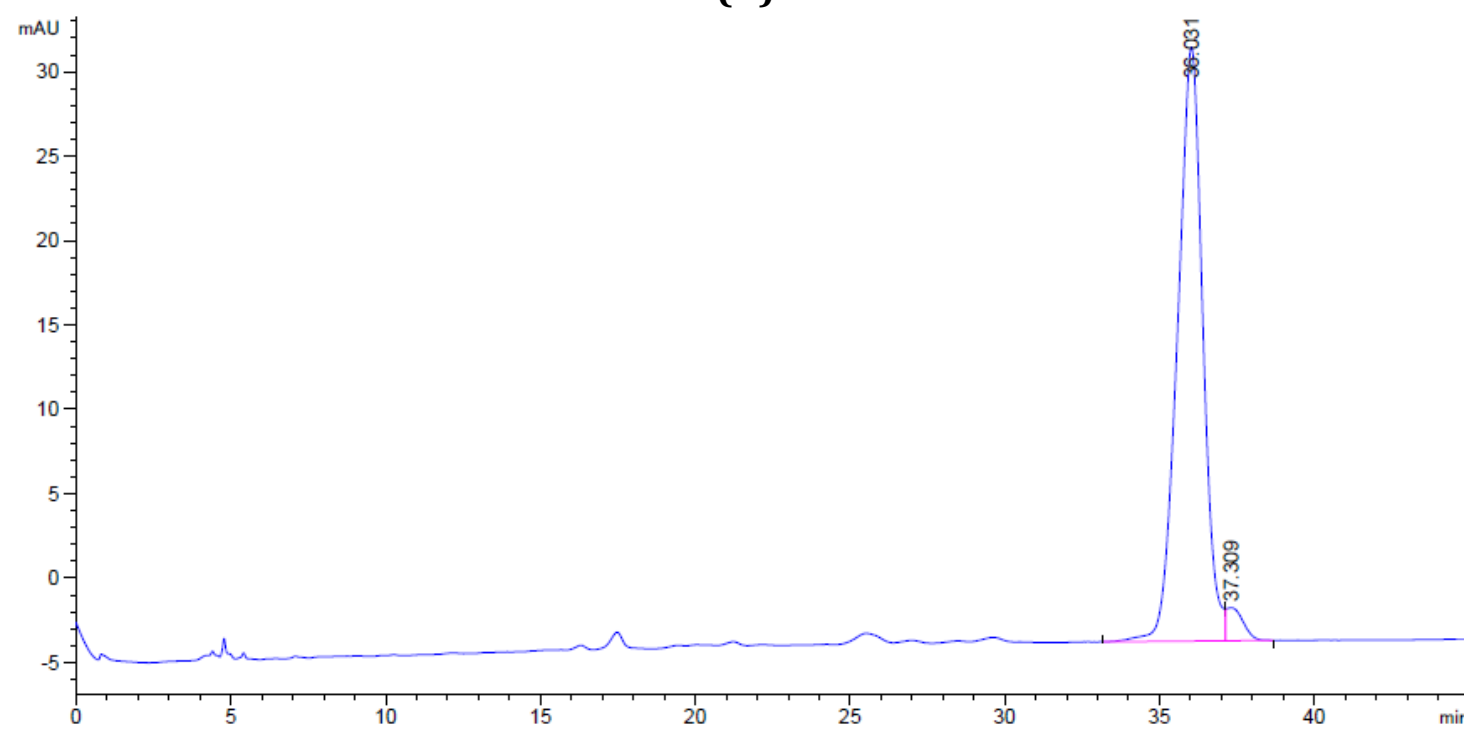

\begin{tabular}{cccccc} 
Peak & $\begin{array}{c}\text { RetTime } \\
(\mathrm{min})\end{array}$ & $\begin{array}{c}\text { Width } \\
(\mathrm{min})\end{array}$ & $\begin{array}{c}\text { Height } \\
(\mathrm{mAU})\end{array}$ & $\begin{array}{c}\text { Area } \\
(\mathrm{mAU} * \mathrm{~s})\end{array}$ & Area \% \\
\hline 1 & 36.031 & 0.83 & 35.18079 & 1996.32 & 96.4257 \\
2 & 37.309 & 0.5538 & 1.95396 & 73.99968 & 3.5743
\end{tabular}<smiles>COc1ccc(CCCC(C)Cl)cc1</smiles>

Borylation of Enantioenriched (R)-SI-6: A flame-dried vial was charged with $\mathrm{MnBr}_{2}$ (1.8 mg, $5 \mathrm{~mol} \%$ ) and $\mathrm{B}_{2} \mathrm{pin}_{2}(56.1 \mathrm{mg}, 1.3$ equiv) before evacuating and back-filling with $\mathrm{N}_{2}$. DME $(170 \mu \mathrm{L}, 1.0 \mathrm{M})$ was added, followed by TMEDA $(1.5 \mu \mathrm{L}, 5$ mol \%). Next, ethylmagnesium bromide ( $3 \mathrm{M}$ in $\mathrm{Et}_{2} \mathrm{O}, 75 \mu \mathrm{L}$, 1.3 equiv) was added dropwise to the reaction mixture at a rate of two drops/sec (approximately $5 \mathrm{sec}$ total addition time). Finally, (R)-1-(4-chloropentyl)-4-methoxybenzene ((R)-SI-6) (35.6 mg, $0.17 \mathrm{mmol}, 1$ equiv) was added to the reaction mixture at once. The reaction mixture was stirred at room temperature for 4 hours. Reaction was quenched with $1 \mathrm{~mL} \mathrm{HCl}(1 \mathrm{M})$, extracted with $\mathrm{Et}_{2} \mathrm{O}(3 \times 2 \mathrm{~mL})$, dried over $\mathrm{MgSO}_{4}$, and concentrated under reduced pressure. The crude residue was purified by silica gel chromatography $\left(16 \mathrm{~g} \mathrm{SiO}_{2}, 0 \%-15 \%\right.$ EtOAc in hexanes, $1 \% / 22 \mathrm{~mL}, 25 \mathrm{~mL} / \mathrm{min}$ ) to yield rac-SI-7 (26.8 mg, 53\% yield) as a colorless liquid. 
<smiles>COc1ccc(CCCC(C)B2OC(C)(C)C(C)(C)O2)cc1</smiles>

Oxidation of (SI-7). To a 3-dram vial equipped with a stir bar was added 2-(5-(4methoxyphenyl)pentan-2-yl)-4,4,5,5-tetramethyl-1,3,2-dioxaborolane (SI-7) (26.8 $\mathrm{mg}, 0.09 \mathrm{mmol})$ and THF (0.5 mL, $0.5 \mathrm{M})$ and the vial was placed in an ice bath. In a separate 2 dram vial with a stir bar was placed in an ice bath and $0.5 \mathrm{~mL} \mathrm{NaOH}(2$ M) was added followed by $\mathrm{H}_{2} \mathrm{O}_{2}(30 \%$ aqueous, $120 \mu \mathrm{L})$ and the solution was stirred at $0{ }^{\circ} \mathrm{C}$. After 1 minute, $300 \mu \mathrm{L}$ of the basic peroxide solution was added to $\mathbf{S I - 7}$ at 0 ${ }^{\circ} \mathrm{C}$ and the mixture was allowed to warm to room temperature. After 2 hours, the mixture was diluted with $2 \mathrm{~mL} \mathrm{H}_{2} \mathrm{O}$ and $2 \mathrm{~mL} \mathrm{Et}_{2} \mathrm{O}$, the layers were separated, and the aqueous layer was washed $3 \mathrm{x}$ with $2 \mathrm{~mL} \mathrm{Et} 2 \mathrm{O}$. The combined organics were dried over $\mathrm{MgSO}_{4}$, concentrated under reduced pressure and purified by silica gel chromatography (30\% EtOAc in hexanes $\mathrm{R}_{\mathrm{f}}=0.3$ ) to yield SI-5 (15.6 mg, 91\%). Enantiomeric excess of the product was determined to be $0 \%$ ee by chiral stationary phase HPLC analysis (Cellulose-1 $(\Phi 250 \mathrm{~mm} \times 4.60 \mathrm{~mm}), 2$-propanol $/ \mathrm{n}$-hexane $=$ $1 / 99$, flow rate $0.75 \mathrm{~mL} / \mathrm{min}$, detection at $280 \mathrm{~nm}$, $\mathrm{tR}=32.3 \mathrm{~min}, 37.6 \mathrm{~min}$ ).

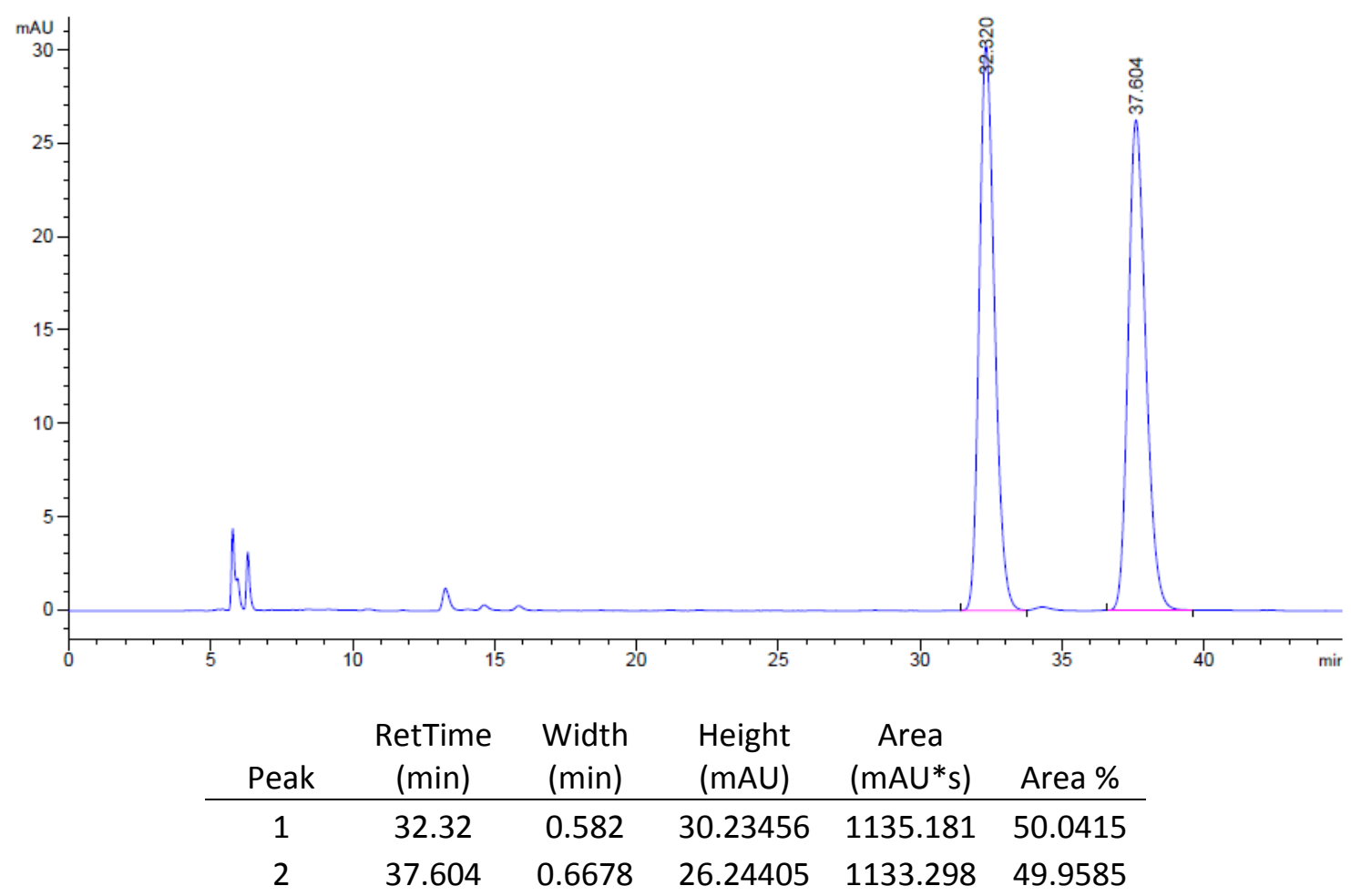




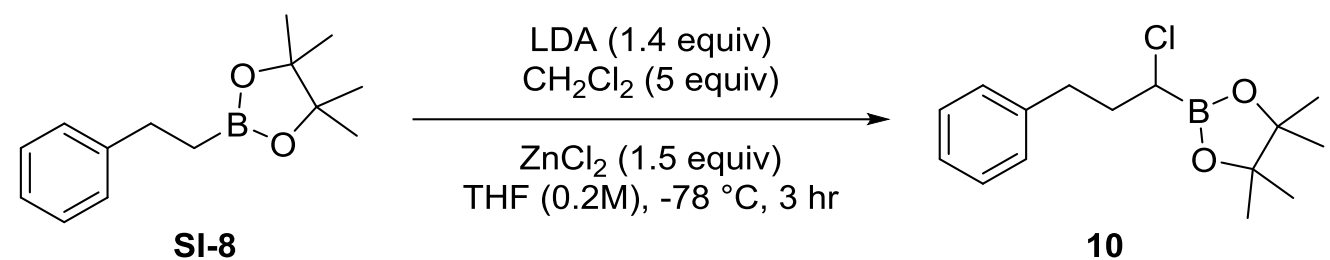

2-(1-Chloro-3-phenylpropyl)-4,4,5,5-tetramethyl-1,3,2-dioxaborolane (10). A solution of LDA was prepared: a flame dried, 2 -neck $25 \mathrm{~mL}$ flask equipped with a stir bar was charged with NHiPr2 (552 mg, $770 \mu \mathrm{L}, 5.46 \mathrm{mmol}$ ) and THF (5.5 mL, $1 \mathrm{M})$ cooled to $-78{ }^{\circ} \mathrm{C}$. nBuLi (2.3M in hexanes, $2.4 \mathrm{~mL}, 5.46 \mathrm{mmol}$ ) was added at -78 ${ }^{\circ} \mathrm{C}$ and stirred for 30 minutes. The mixture was warmed to room temperature and stirred for an additional 30 minutes. Meanwhile, a separate flame-dried, $50 \mathrm{~mL}$ round bottom flask was equipped with a stir bar and charged with SI-8 $(900 \mathrm{mg}$, 3.9 $\mathrm{mmol}), \mathrm{CH}_{2} \mathrm{Cl}_{2}(1.2 \mathrm{~mL}, 19.5 \mathrm{mmol})$, and THF ( $\left.8 \mathrm{~mL}, 0.5 \mathrm{M}\right)$ and cooled to $-78{ }^{\circ} \mathrm{C}$. The solution of LDA was cooled back to $-78^{\circ} \mathrm{C}$ and added to the mixture over 5 minutes. $\mathrm{ZnCl}_{2}(800 \mathrm{mg}$, $5.85 \mathrm{mmol}$ ) was dissolved in $6 \mathrm{~mL}$ THF (1M) was added dropwise over 10 minutes to the mixture and reaction was stirred for an additional 3 hours at $-78{ }^{\circ} \mathrm{C}$. The reaction was warmed to room temperature and solvent removed under vacuum. The crude residue was then partitioned between saturated $\mathrm{NH}_{4} \mathrm{Cl}$ and $\mathrm{Et}_{2} \mathrm{O}$ (30 mL each) and the aqueous phase was extracted $2 x$ with $30 \mathrm{~mL} \mathrm{Et} 20$, dried over $\mathrm{MgSO}_{4}$, and concentrated under rotary evaporation to furnish 10 as a colorless oil (893mg, 82\%). The crude product was used without further purification.

${ }^{1} \mathrm{H} \mathrm{NMR}\left(\mathrm{CDCl}_{3}, 400 \mathrm{MHz}\right): \delta 7.33-7.25(\mathrm{~m}, 2 \mathrm{H}), 7.23-7.17(\mathrm{~m}, 3 \mathrm{H}), 3.42(\mathrm{t}, \mathrm{J}=7.4$ $\mathrm{Hz}, 1 \mathrm{H}), 2.92-2.68(\mathrm{~m}, 2 \mathrm{H}), 2.12(\mathrm{q}, \mathrm{J}=7.6 \mathrm{~Hz}, 2 \mathrm{H}), 1.29(\mathrm{~s}, 12 \mathrm{H})$. ${ }^{13} \mathrm{C}$ NMR $\left(\mathrm{CDCl}_{3}, 100 \mathrm{MHz}\right): \delta 141.2,128.8,128.6,126.1,84.6,35.8,33.5,24.8$. HRMS (EI) Calc. for $\mathrm{C}_{15} \mathrm{H}_{22} \mathrm{BClO}_{2}$ [M+], 280.1401. Found: 280.1399. FTIR (NaCl) cm-1: 2979, 2934, 1383, 1346, 1142, 968, 849, 700 


\section{Catalytic Borylation}

Standard Conditions. A flame-dried vial was charged with $\mathrm{MnBr}_{2}$ (1.1 mg, $1 \mathrm{~mol} \%$ ) and $\mathrm{B}_{2}$ pin 2 (165.1 mg, 1.3 equiv) before evacuating and back-filling with $\mathrm{N}_{2}$. DME $(500 \mu \mathrm{L}, 1.0 \mathrm{M})$ was added, followed by $1 \mathrm{~mol} \%$ TMEDA $(10 \mu \mathrm{L}$ of a $4 \%(\mathrm{v} / \mathrm{v})$ solution of TMEDA in DME). Next, ethylmagnesium bromide (3M in Et $20,220 \mu \mathrm{L}, 1.3$ equiv) was added dropwise to the reaction mixture at a rate of two drops/sec (approximately $20 \mathrm{sec}$ total addition time). Finally, substrate ( $0.5 \mathrm{mmol}, 1$ equiv) was added to the reaction mixture at once. The reaction mixture was stirred at room temperature for 4 hours. The reaction was quenched with $2 \mathrm{~mL} \mathrm{HCl} \mathrm{(1M),} \mathrm{extracted}$ with $\mathrm{Et}_{2} \mathrm{O}(3 \times 4 \mathrm{~mL})$, dried over $\mathrm{MgSO}_{4}$, and concentrated under reduced pressure. The crude residue was purified by silica gel chromatography (EtOAc in hexanes) to yield the product.

Conditions A. A flame-dried vial was charged with $\mathrm{MnBr}_{2}(2.7 \mathrm{mg}, 5 \mathrm{~mol} \%)$ and $B_{2}$ pinz (82.5 mg, 1.3 equiv) before evacuating and back-filling with $\mathrm{N}_{2}$. DME $(500 \mu \mathrm{L}$, $0.5 \mathrm{M})$ was added, followed by TMEDA ( $2 \mu \mathrm{L}, 5 \mathrm{~mol} \%)$, and the vial was placed in an ice bath. Next, ethylmagnesium bromide ( $3 \mathrm{M}$ in $\mathrm{Et}_{2} \mathrm{O}, 110 \mu \mathrm{L}, 1.3$ equiv) was added dropwise to the reaction mixture at a rate of two drops/sec (approximately $10 \mathrm{sec}$ total addition time) and the reaction was allowed to stir for 2 minutes. Finally, substrate $(0.25 \mathrm{mmol}, 1$ equiv) was added to the reaction mixture at once. The reaction mixture was stirred at $0{ }^{\circ} \mathrm{C}$ for 4 hours. The reaction was quenched with 1 mL $\mathrm{HCl}(1 \mathrm{M})$, extracted with $\mathrm{Et}_{2} \mathrm{O}(3 \times 2 \mathrm{~mL})$, dried over $\mathrm{MgSO}_{4}$, and concentrated under reduced pressure. The crude residue was purified by silica gel chromatography (EtOAc in hexanes) to yield the product.

Conditions B. A flame-dried vial was charged with $\mathrm{MnBr}_{2}(0.5 \mathrm{mg}, 1 \mathrm{~mol} \%)$ and B2pinz ( $82.5 \mathrm{mg}, 1.3$ equiv) before evacuating and back-filling with $\mathrm{N}_{2}$. DME $(2.5 \mathrm{~mL}$, $0.1 \mathrm{M})$ was added, followed by $1 \mathrm{~mol} \%$ TMEDA $(10 \mu \mathrm{L}$ of a $\%$ (v/v) solution of TMEDA in DME). Next, ethylmagnesium bromide (3M in $\mathrm{Et}_{2} \mathrm{O}, 110 \mu \mathrm{L}, 1.3$ equiv) was added dropwise to the reaction mixture at a rate of two drops/sec (approximately $10 \mathrm{sec}$ total addition time), and the vial was placed in an oil bath set to $65^{\circ} \mathrm{C}$ and stirred for 2 minutes. Finally, substrate $(0.25 \mathrm{mmol}, 1$ equiv) was added to the reaction mixture at once. The reaction mixture was stirred at $65^{\circ} \mathrm{C}$ for 4 hours. The vial was then removed and allowed to cool to room temperature before quenching. The reaction was quenched with $1 \mathrm{~mL} \mathrm{HCl}(1 \mathrm{M})$, extracted with $\mathrm{Et}_{2} \mathrm{O}(3 \times 2 \mathrm{~mL})$, dried over $\mathrm{MgSO}_{4}$, and concentrated under reduced pressure. The crude residue was purified by silica gel chromatography (EtOAc in hexanes) to yield the product.

Conditions C. A flame-dried vial was charged with $\mathrm{MnBr}_{2}(2.7 \mathrm{mg}$, $5 \mathrm{~mol} \%)$ and B2pin2 (158.7 mg, 2.5 equiv) before evacuating and back-filling with N2. DME ( 0.5 $\mu \mathrm{L}, 0.5 \mathrm{M}$ ) was added, followed by TMEDA ( $2 \mu \mathrm{L}, 5 \mathrm{~mol} \%)$. Next, ethylmagnesium bromide (3M in $\mathrm{Et}_{2} \mathrm{O}, 210 \mu \mathrm{L}, 2.5$ equiv) was added dropwise to the reaction mixture at a rate of two drops/sec (approximately 20 sec total addition time). Finally, substrate $(0.25 \mathrm{mmol}, 1$ equiv) was added to the reaction mixture at once. The reaction mixture was stirred at room temperature for 4 hours. The reaction was quenched with $1 \mathrm{~mL} \mathrm{HCl}(1 \mathrm{M})$, extracted with $\mathrm{Et}_{2} \mathrm{O}\left(3 \times 2 \mathrm{~mL}\right.$ ), dried over $\mathrm{MgSO}_{4}$, 
and concentrated under reduced pressure. The crude residue was purified by silica gel chromatography (EtOAc in hexanes) to yield the product.

Conditions D. A flame-dried vial was charged with $\mathrm{MnBr}_{2}(1.1 \mathrm{mg}, 1 \mathrm{~mol} \%)$ and $B_{2}$ pin. (292.0 mg, 2.3 equiv) before evacuating and back-filling with $\mathrm{N}_{2}$. DME (500 $\mu \mathrm{L}, 1.0 \mathrm{M}$ ) was added, followed by $1 \mathrm{~mol} \%$ TMEDA (10 $\mu \mathrm{L}$ of a $4 \%(\mathrm{v} / \mathrm{v})$ solution of TMEDA in DME). Next, ethylmagnesium bromide ( $3 \mathrm{M}$ in $\mathrm{Et}_{2} \mathrm{O}$, $385 \mu \mathrm{L}$, 2.3 equiv) was added dropwise to the reaction mixture at a rate of two drops/sec (approximately $10 \mathrm{sec}$ total addition time). Finally, substrate $(0.5 \mathrm{mmol}, 1$ equiv) was added to the reaction mixture at once. The reaction mixture was stirred at room temperature for 4 hours. $1 \mathrm{~mL} \mathrm{HCl} \mathrm{(1M)} \mathrm{was} \mathrm{added} \mathrm{and} \mathrm{the} \mathrm{reaction} \mathrm{was} \mathrm{extracted} \mathrm{with} \mathrm{Et}_{2} \mathrm{O}(3 \times 2$ $\mathrm{mL}$ ), dried over $\mathrm{MgSO}_{4}$, and the organics concentrated under reduced pressure. The crude residue was purified by silica gel chromatography (EtOAc in hexanes) to yield the product. 


\section{Compounds \\ Boronic Esters}<smiles>CC1(C)OB(CCCc2ccccc2)OC1(C)C</smiles>

4,4,5,5-tetramethyl-2-(3-phenylpropyl)-1,3,2-dioxaborolane (2a). 1-Chloro-3phenylpropane (1a) (77.2 $\mathrm{mg}, 71.5 \mu \mathrm{L}, 0.5 \mathrm{mmol})$ was treated under Standard Conditions. Silica gel chromatography $\left(16 \mathrm{~g} \mathrm{SiO}_{2}, 1 \%-12 \%\right.$ EtOAc in hexanes, $1 \% / 20 \mathrm{~mL}, 25 \mathrm{~mL} / \mathrm{min}$ ) yielded $\mathbf{2 a}(72.3 \mathrm{mg}, 59 \%$ yield) as a clear liquid which matched the literature spectra. $15.7 \mathrm{mg}(21 \%)$ of unreacted starting material was recovered from the reaction. ${ }^{16}$

1-Bromo-3-phenylpropane (1b) (99.6 mg, $76 \mu \mathrm{L}, 0.5 \mathrm{mmol})$ was treated under Standard Conditions. . Silica gel chromatography yielded $\mathbf{2 a}$ ( $92.1 \mathrm{mg}, 75 \%$ yield) as a clear liquid.

${ }^{1} \mathrm{H} \mathrm{NMR}\left(\mathrm{CDCl}_{3}, 400 \mathrm{MHz}\right): \delta 7.32-7.22(\mathrm{~m}, 2 \mathrm{H}), 7.23-7.13(\mathrm{~m}, 3 \mathrm{H}), 2.62(\mathrm{t}, \mathrm{J}=7.6$ $\mathrm{Hz}, 2 \mathrm{H}), 1.74(\mathrm{p}, \mathrm{J}=7.8 \mathrm{~Hz}, 2 \mathrm{H}), 1.25(\mathrm{~s}, 12 \mathrm{H}), 0.84(\mathrm{t}, \mathrm{J}=7.9 \mathrm{~Hz}, 2 \mathrm{H})$.

${ }^{13} \mathrm{C} \mathrm{NMR}\left(\mathrm{CDCl}_{3}, 100 \mathrm{MHz}\right): \delta 143.1,129.0,128.6,126.0,83.4,39.0,26.6,25.3$.<smiles>COc1ccc(CCC(C)B2OC(C)(C)C(C)(C)O2)cc1</smiles>

2-(4-(4-methoxyphenyl)butan-2-yl)-4,4,5,5-tetramethyl-1,3,2-dioxaborolane (2c). 1-(3-chlorobutyl)-4-methoxybenzene (1c) $(99.2 \mathrm{mg}, 94.5 \mu \mathrm{L}, 0.5 \mathrm{mmol})$ was treated under Standard Conditions. Silica gel chromatography (16g SiO2, 0\%-15\% EtOAc in hexanes, $1 \% / 22 \mathrm{~mL}, 25 \mathrm{~mL} / \mathrm{min}$ ) yielded 2 c (127.1 $\mathrm{mg}$, $88 \%$ yield) as a clear liquid which matched the literature spectra. ${ }^{3}$

1-(3-bromobutyl)-4-methoxybenzene (1d) (121.6 mg, 96.5 $\mu \mathrm{L}, 0.5 \mathrm{mmol})$ was treated under Standard Conditions. Silica gel chromatography yielded 2c $(131.6 \mathrm{mg}$, $91 \%$ yield) as a clear liquid.

1-(3-iodobutyl)-4-methoxybenzene (1e) (72.5 mg, $0.25 \mathrm{mmol}$ ) was treated under Standard Conditions. Silica gel chromatography yielded 2c (49.7 mg, 68\% yield) as a clear liquid.

${ }^{1} \mathrm{H} \mathrm{NMR}\left(\mathrm{CDCl}_{3}, 400 \mathrm{MHz}\right): \delta 7.12(\mathrm{~d}, \mathrm{~J}=8.6 \mathrm{~Hz}, 2 \mathrm{H}), 6.82(\mathrm{~d}, \mathrm{~J}=8.5 \mathrm{~Hz}, 2 \mathrm{H}), 3.78(\mathrm{~s}$, $3 \mathrm{H}), 2.58(\mathrm{t}, \mathrm{J}=8.1 \mathrm{~Hz}, 2 \mathrm{H}), 1.84-1.70(\mathrm{~m}, 1 \mathrm{H}), 1.63-1.50(\mathrm{~m}, 1 \mathrm{H}), 1.26(\mathrm{~s}, 12 \mathrm{H})$, $1.14-0.99(\mathrm{~m}, 4 \mathrm{H})$. ${ }^{13} \mathrm{C}$ NMR $\left(\mathrm{CDCl}_{3}, 100 \mathrm{MHz}\right): \delta 157.7,135.3,129.4,113.7,82.9,55.3,35.6,34.5,24.9$, $24.8,15.5$. 
<smiles>[Z17]OB1OC(C)(C)C(C)(C)O1</smiles>

2-(4-(4-methoxyphenyl)-2-methylbutan-2-yl)-4,4,5,5-tetramethyl-1,3,2-

dioxaborolane (2f). 1-(3-chloro-3-methylbutyl)-4-methoxybenzene (1f) (106.4 mg, $0.5 \mathrm{mmol}$ ) was treated under Standard Conditions. Silica gel chromatography $(16 \mathrm{~g}$ $\mathrm{SiO}_{2}, 0 \%-15 \%$ EtOAc in hexanes, 1\%/22mL, $\left.25 \mathrm{~mL} / \mathrm{min}\right)$ yielded $\mathbf{2 f}(108.7 \mathrm{mg}, 71 \%$ yield) as a white solid which matched the literature spectra. ${ }^{3}$

1-(3-bromo-3-methylbutyl)-4-methoxybenzene (1g) (128.5 mg, $0.5 \mathrm{mmol}$ ) was

treated under Standard Conditions. Silica gel chromatography yielded $\mathbf{2 f}(126.1 \mathrm{mg}$, $83 \%$ yield) as a white solid.

${ }^{1} \mathrm{H} \mathrm{NMR}\left(\mathrm{CDCl}_{3}, 400 \mathrm{MHz}\right): \delta 7.13(\mathrm{~d}, \mathrm{~J}=8.5 \mathrm{~Hz}, 2 \mathrm{H}), 6.83(\mathrm{~d}, \mathrm{~J}=8.6 \mathrm{~Hz}, 2 \mathrm{H}), 3.79(\mathrm{~s}$, $3 \mathrm{H}), 2.58-2.48(\mathrm{~m}, 2 \mathrm{H}), 1.62-1.53(\mathrm{~m}, 2 \mathrm{H}), 1.27(\mathrm{~s}, 12 \mathrm{H}), 1.02(\mathrm{~s}, 6 \mathrm{H})$.

${ }^{13} \mathrm{C} \mathrm{NMR}\left(\mathrm{CDCl}_{3}, 100 \mathrm{MHz}\right): \delta 157.7,135.8,129.3,113.8,83.1,55.3,43.9,32.3,24.9$, 24.9.

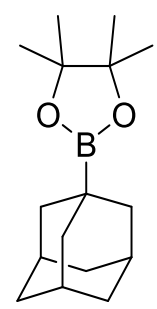

$2 \mathrm{~h}$

2-((3r,5r,7r)-adamantan-1-yl)-4,4,5,5-tetramethyl-1,3,2-dioxaborolane (2h). 1Chloroadamantane (1h) $(85.3 \mathrm{mg}, 0.5 \mathrm{mmol})$ was treated under Standard Conditions. Silica gel chromatography (5\% EtOAc in hexanes, $\mathrm{R}_{\mathrm{f}}=0.2$ ) yielded $\mathbf{2 h}$ (109.1 mg, 83\% yield) as a white solid which matched the literature spectra. ${ }^{17}$

${ }^{1} \mathrm{H} \mathrm{NMR}\left(\mathrm{CDCl}_{3}, 500 \mathrm{MHz}\right): \delta 1.87-1.81(\mathrm{~m}, 3 \mathrm{H}), 1.77-1.72(\mathrm{~m}, 12 \mathrm{H}), 1.20(\mathrm{~s}, 12 \mathrm{H})$. ${ }^{13} \mathrm{C} \mathrm{NMR}\left(\mathrm{CDCl}_{3}, 125 \mathrm{MHz}\right): \delta 82.7,38.1,37.6,27.7,24.8$. 


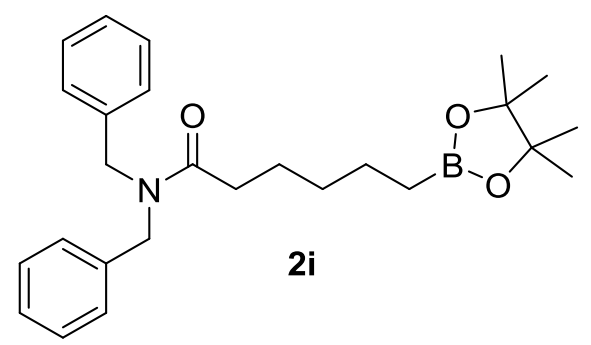

$N, N$-Dibenzyl-6-(4,4,5,5-tetramethyl-1,3,2-dioxaborolan-2-yl)hexanamide (2i). $N, N$ Dibenzyl-6-chlorohexanamide (1i) (87.5 $\mathrm{mg}, 0.25 \mathrm{mmol}$ ) was treated under Conditions C. Silica gel chromatography $\left(25 \mathrm{~g} \mathrm{SiO}_{2}, 5 \%-40 \%\right.$ EtOAc in hexanes, $1 \% / 9 \mathrm{~mL}, 40 \mathrm{~mL} / \mathrm{min}$ ) yielded $\mathbf{2 i}$ (61.6 $\mathrm{mg}, 58 \%$ yield) as a white solid. $N, N$-Dibenzyl-6-chlorohexanamide (1j) (187.2 mg, $0.5 \mathrm{mmol})$ was treated under Standard Conditions. Silica gel chromatography yielded $\mathbf{2 i}$ ( $127.3 \mathrm{mg}, 60 \%$ yield) as a white solid.

${ }^{1} \mathrm{H} \mathrm{NMR}\left(\mathrm{CDCl}_{3}, 500 \mathrm{MHz}\right): \delta 7.39-7.34(\mathrm{~m}, 2 \mathrm{H}), 7.34-7.27(\mathrm{~m}, 4 \mathrm{H}), 7.23-7.18(\mathrm{~m}$, $2 \mathrm{H}), 7.17-7.12(\mathrm{~m}, 2 \mathrm{H}), 4.59(\mathrm{~s}, 2 \mathrm{H}), 4.43(\mathrm{~s}, 2 \mathrm{H}), 2.44-2.37(\mathrm{~m}, 2 \mathrm{H}), 1.76-1.65$ $(\mathrm{m}, 2 \mathrm{H}), 1.46-1.37(\mathrm{~m}, 2 \mathrm{H}), 1.37-1.31(\mathrm{~m}, 2 \mathrm{H}), 1.23(\mathrm{~s}, 12 \mathrm{H}), 0.76(\mathrm{t}, \mathrm{J}=7.7 \mathrm{~Hz}$, $2 \mathrm{H})$.

${ }^{13} \mathrm{C}$ NMR (CDCl $\left.3,125 \mathrm{MHz}\right): \delta 173.9,137.7,136.8,129.0,128.7,128.4,127.7,127.4$, 126.5, 83.0, 50.0, 48.1, 33.4, 32.4, 25.4, 24.9, 23.9.

HRMS (EI) Calc. for $\mathrm{C}_{26} \mathrm{H}_{36} \mathrm{BNO}_{3}$ [M+], 421.2788. Found: 421.2795 .

FTIR (NaCl) cm-1: 3030, 2977, 2927, 2860, 1651, 1371, 1145, 700<smiles>CC1(C)OB(CCCCCC(=O)OCc2ccccc2)OC1(C)C</smiles>

Benzyl 6-(4,4,5,5-tetramethyl-1,3,2-dioxaborolan-2-yl)hexanoate (2k). Benzyl 6chlorohexanoate (1k) $(120.1 \mathrm{mg}, 0.5 \mathrm{mmol})$ was treated under Conditions C. Silica gel chromatography $\left(25 \mathrm{~g} \mathrm{SiO}_{2}, 5 \%-40 \%\right.$ EtOAc in hexanes, $\left.1 \% / 9 \mathrm{~mL}, 25 \mathrm{~mL} / \mathrm{min}\right)$ yielded 2k (23.4 mg, 14\% yield) as a clear liquid.

Benzyl 6-chlorohexanoate (11) (142.5 mg, $0.5 \mathrm{mmol})$ was treated under Standard Conditions. Silica gel chromatography yielded $2 \mathbf{k}$ (107.1 $\mathrm{mg}$, 64\% yield) as a clear liquid.

${ }^{1} \mathrm{H} \mathrm{NMR}\left(\mathrm{CDCl}_{3}, 400 \mathrm{MHz}\right): \delta 7.40-7.28(\mathrm{~m}, 5 \mathrm{H}), 5.10(\mathrm{~s}, 2 \mathrm{H}), 2.35(\mathrm{t}, \mathrm{J}=7.6 \mathrm{~Hz}, 2 \mathrm{H})$, $1.70-1.59(\mathrm{~m}, 2 \mathrm{H}), 1.47-1.37(\mathrm{~m}, 2 \mathrm{H}), 1.37-1.28(\mathrm{~m}, 2 \mathrm{H}), 1.26-1.20(\mathrm{~m}, 12 \mathrm{H})$, $1.23(\mathrm{~s}, 12 \mathrm{H}), 0.76(\mathrm{t}, \mathrm{J}=7.7 \mathrm{~Hz}, 2 \mathrm{H})$.

${ }^{13} \mathrm{C}$ NMR $\left(\mathrm{CDCl}_{3}, 100 \mathrm{MHz}\right): \delta$ 173.8, 136.3, 128.7, 128.3, 83.0, 66.2, 34.4, 32.0, 25.0, 24.9, 23.8.

HRMS (EI) Calc. for $\mathrm{C}_{19} \mathrm{H}_{29} \mathrm{BO}_{4}$ [M+], 332.2159. Found: 332.2143 .

FTIR (NaCl) cm-1: 2977, 2932, 2863, 1737, 1379, 1146 
<smiles>CC1(C)OB([C@]2(C)CC[C@H](c3ccccc3)CC2)OC1(C)C</smiles>

4,4,5,5-Tetramethyl-2-((1s,4s)-1-methyl-4-phenylcyclohexyl)-1,3,2-dioxaborolane (2m). (4-Chloro-4-methylcyclohexyl)benzene (1m) (55mg, $0.25 \mathrm{mmol}$ ) was treated under Standard Conditions. Silica gel chromatography (5\% EtOAc in hexanes, $\mathrm{R}_{\mathrm{f}}=$ 0.2 ) yielded and inseparable mixture (2:1 cis:trans) of $2 \mathbf{m ~ ( 5 1 . 6 ~ m g , ~ 6 5 \% ~ y i e l d ) ~ a s ~ a ~}$ colorless liquid which matched the literature spectra. ${ }^{17}$

${ }^{1} \mathrm{H} \mathrm{NMR}\left(\mathrm{CDCl}_{3}, 400 \mathrm{MHz}\right): . \delta 7.34-7.27(\mathrm{~m}, 2 \mathrm{H}), 7.24(\mathrm{~s}, 1 \mathrm{H}), 7.22-7.16(\mathrm{~m}, 2 \mathrm{H})$, $2.58-2.39(\mathrm{~m}, 1 \mathrm{H}), 2.04(\mathrm{~d}, \mathrm{~J}=12.9 \mathrm{~Hz}, 1 \mathrm{H}), 1.91-1.82(\mathrm{~m}, 1 \mathrm{H}), 1.81-1.63(\mathrm{~m}, 5 \mathrm{H})$, $1.63-1.49(\mathrm{~m}, 2 \mathrm{H}), 1.30(\mathrm{~s}, 4 \mathrm{H}), 1.27(\mathrm{~s}, 12 \mathrm{H}), 1.11(\mathrm{~s}, 3 \mathrm{H}), 0.99(\mathrm{~s}, 2 \mathrm{H})$.

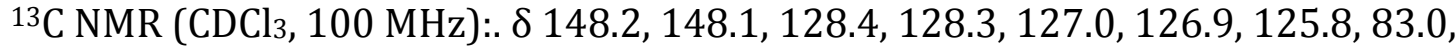
$82.9,44.5,44.2,37.6,33.8,33.0,28.1,26.3,24.9,24.8,24.8,18.7$.

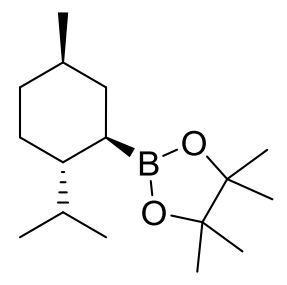

2n

2-((1R,2R,5R)-2-isopropyl-5-methylcyclohexyl)-4,4,5,5-tetramethyl-1,3,2-N (2n). Neomenthyl chloride (1n) (87.4 mg, $93 \mu \mathrm{L}, 0.5 \mathrm{mmol}$ ) was treated under Standard Conditions. Silica gel chromatography ( $5 \%$ EtOAc in hexanes, $\mathrm{R}_{\mathrm{f}}=0.2$ ) yielded $\mathbf{2 n}$ (104.1 mg, 78\%) as a clear liquid which matched the literature spectra. ${ }^{18}$ Diastereomeric ratio was determined from GC peak ratios.

(-)-Menthyl chloride (10) (87.4 mg, $93 \mu \mathrm{L}, 0.5 \mathrm{mmol})$ was treated under Standard Conditions. Silica gel chromatography (5\% EtOAc in hexanes, $R_{f}=0.2$ ) yielded $2 \mathbf{n}$ $(79.1 \mathrm{mg}, 59 \%)$ as a clear liquid. Diastereomeric ratio was determined from GC peak ratios.

${ }^{1} \mathrm{H} \mathrm{NMR}\left(\mathrm{CDCl}_{3}, 500 \mathrm{MHz}\right): \delta 1.70(\mathrm{dq}, \mathrm{J}=9.3,3.1 \mathrm{~Hz}, 1 \mathrm{H}), 1.61(\mathrm{ddt}, \mathrm{J}=15.1,8.4,3.0$ $\mathrm{Hz}, 3 \mathrm{H}), 1.32-1.24(\mathrm{~m}, 2 \mathrm{H}), 1.22(\mathrm{~d}, \mathrm{~J}=2.4 \mathrm{~Hz}, 12 \mathrm{H}), 0.96-0.90(\mathrm{~m}, 4 \mathrm{H}), 0.89$ (d, J = $6.9 \mathrm{~Hz}, 3 \mathrm{H}), 0.83(\mathrm{~d}, \mathrm{~J}=6.5 \mathrm{~Hz}, 3 \mathrm{H}), 0.76(\mathrm{~d}, \mathrm{~J}=6.9 \mathrm{~Hz}, 3 \mathrm{H})$. ${ }^{13} \mathrm{C} \mathrm{NMR}\left(\mathrm{CDCl}_{3}, 125 \mathrm{MHz}\right): \delta$ 82.6, 43.8, 37.2, 35.3, 33.5, 32.0, 25.9, 24.7, 24.7, 22.7, 21.6, 16.5 . 


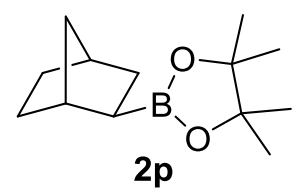

2-((1R,2R,4R)-bicyclo[2.2.1]heptan-2-yl)-4,4,5,5-tetramethyl-1,3,2-dioxaborolane (2p). Exo-2-Chloronorbornane SI-X (65.3 mg, $65 \mu \mathrm{L}, 0.5 \mathrm{mmol})$ was treated under Standard Conditions. Silica gel chromatography (5\% EtOAc in hexanes, $\left.\mathrm{Rf}_{\mathrm{f}}=0.2\right)$ yielded $2 \mathbf{p}$ (88.3 mg, 79\%) as a clear liquid which matched the literature spectra. ${ }^{17}$ Diastereomeric ratio was determined from GC peak ratios.

Exo-2-Bromonorbornane ( $87.5 \mathrm{mg}, 64 \mu \mathrm{L}, 0.5 \mathrm{mmol}$ ) was treated under Standard Conditions. Silica gel chromatography ( $5 \%$ EtOAc in hexanes, $\left.\mathrm{R}_{\mathrm{f}}=0.2\right)$ yielded $\mathbf{2 p}$ (88.3 mg, 79\%) as a clear liquid which matched the literature spectra. ${ }^{17}$

Diastereomeric ratio was determined from GC peak ratios.

${ }^{1} \mathrm{H} \mathrm{NMR}\left(\mathrm{CDCl}_{3}, 400 \mathrm{MHz}\right): \delta 2.26(\mathrm{~s}, 1 \mathrm{H}), 2.20(\mathrm{~s}, 1 \mathrm{H}), 1.57-1.38(\mathrm{~m}, 3 \mathrm{H}), 1.39-$ $1.27(\mathrm{~m}, 1 \mathrm{H}), 1.23-1.19(\mathrm{~m}, 14 \mathrm{H}), 1.18-1.10(\mathrm{~m}, 2 \mathrm{H}), 0.90-0.81(\mathrm{~m}, 1 \mathrm{H})$.

${ }^{13} \mathrm{C}$ NMR (CDCl $\left.3,100 \mathrm{MHz}\right): \delta 82.9,38.8,38.3,36.8,32.3,32.3,29.4,24.8$.

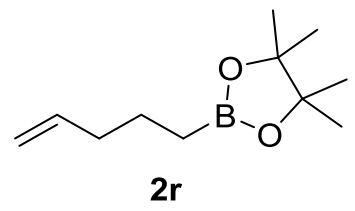

4,4,5,5-tetramethyl-2-(pent-4-en-1-yl)-1,3,2-dioxaborolane (2r). 5-Bromo-1pentene (1r) $(74.2 \mathrm{mg}, 59 \mu \mathrm{L}, 0.5 \mathrm{mmol})$ was treated under Standard Conditions. Silica gel chromatography (5\% EtOAc in hexanes, $\left.\mathrm{R}_{\mathrm{f}}=0.2\right)$ yielded $2 \mathbf{r}(85.6 \mathrm{mg}, 87 \%$ yield) as a clear liquid which matched the literature spectra. ${ }^{19}$

${ }^{1} \mathrm{H}$ NMR ( $\left.\mathrm{CDCl}_{3}, 500 \mathrm{MHz}\right): \delta 5.85-5.72(\mathrm{~m}, 1 \mathrm{H}), 5.03-4.86(\mathrm{~m}, 2 \mathrm{H}), 2.09-1.99(\mathrm{~m}$, $2 \mathrm{H}), 1.50(\mathrm{p}, \mathrm{J}=7.7 \mathrm{~Hz}, 2 \mathrm{H}), 1.23(\mathrm{~s}, 12 \mathrm{H}), 0.78(\mathrm{t}, \mathrm{J}=7.9 \mathrm{~Hz}, 2 \mathrm{H})$.

${ }^{13} \mathrm{C}$ NMR (CDCl, $125 \mathrm{MHz}$ ): $\delta$ 139.1, 114.6, 83.0, 36.5, 25.0, 23.5.
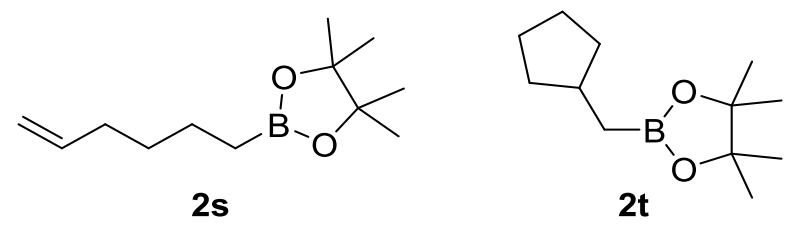

2-(hex-5-en-1-yl)-4,4,5,5-tetramethyl-1,3,2-dioxaborolane (2s) and 2(cyclopentylmethyl)-4,4,5,5-tetramethyl-1,3,2-dioxaborolane (2t). 6-Bromo-1hexene (1s) (81.7 mg, $67 \mu \mathrm{L}, 0.5 \mathrm{mmol})$ was treated under Standard Conditions. Silica gel chromatography ( $5 \%$ EtOAc in hexanes, $\mathrm{R}_{\mathrm{f}}=0.2$ ) yielded an inseparable $3: 1$ mixture of $2 \mathbf{s}$ and $\mathbf{2 t}$ ( $69.2 \mathrm{mg}, 66 \%$ yield) as a clear liquid. 6-Bromo-1-hexene (1s) $(81.7 \mathrm{mg}, 67 \mu \mathrm{L}, 0.5 \mathrm{mmol})$ was treated under Conditions A. Silica gel chromatography yielded 2 s $(73.2 \mathrm{mg}$, 70\% yield, $79 \%$ GC yield) as a clear liquid which matched the literature spectra. ${ }^{20}$ 
${ }^{1} \mathrm{H} \mathrm{NMR}\left(\mathrm{CDCl}_{3}, 500 \mathrm{MHz}\right): \delta 5.88-5.74(\mathrm{~m}, 1 \mathrm{H}), 5.04-4.87(\mathrm{~m}, 2 \mathrm{H}), 2.08-1.99(\mathrm{~m}$, $2 \mathrm{H}), 1.46-1.35(\mathrm{~m}, 4 \mathrm{H}), 1.24(\mathrm{~s}, 12 \mathrm{H}), 0.78(\mathrm{t}, \mathrm{J}=7.3 \mathrm{~Hz}, 2 \mathrm{H})$.

${ }^{13} \mathrm{C} \mathrm{NMR}\left(\mathrm{CDCl}_{3}, 125 \mathrm{MHz}\right): \delta 139.3,114.2,83.0,33.7,31.8,25.0,23.7$.

6-Bromo-1-hexene (1s) (81.7 mg, $67 \mu \mathrm{L}, 0.5 \mathrm{mmol})$ was treated under Conditions B. Silica gel chromatography (5\% EtOAc in hexanes, $\mathrm{R}_{\mathrm{f}}=0.2$ ) yielded an inseparable 1:15 mixture of $2 \mathbf{s}$ and $2 \mathbf{t}$ ( $13.5 \mathrm{mg}, 27 \%$ yield, $37 \%$ GC yield) as a clear liquid which matched the literature spectra. ${ }^{21}$

${ }^{1} \mathrm{H} \mathrm{NMR}\left(\mathrm{CDCl}_{3}, 500 \mathrm{MHz}\right): \delta 2.00-1.90(\mathrm{~m}, 1 \mathrm{H}), 1.82-1.73(\mathrm{~m}, 2 \mathrm{H}), 1.64-1.57(\mathrm{~m}$, $2 \mathrm{H}), 1.53-1.46(\mathrm{~m}, 2 \mathrm{H}), 1.24(\mathrm{~s}, 12 \mathrm{H}), 1.11-1.01(\mathrm{~m}, 2 \mathrm{H}), 0.84(\mathrm{~d}, \mathrm{~J}=7.4 \mathrm{~Hz}, 2 \mathrm{H})$. ${ }^{13} \mathrm{C} \mathrm{NMR}\left(\mathrm{CDCl}_{3}, 125 \mathrm{MHz}\right): \delta 83.0,36.3,35.2,25.3,25.0$.<smiles>COc1ccc(CCB2OC(C)(C)C(C)(C)O2)cc1</smiles>

2-(4-methoxyphenethyl)-4,4,5,5-tetramethyl-1,3,2-dioxaborolane (2u). 1-(2chloroethyl)-4-methoxybenzene (1u) (85.3 mg, $0.5 \mathrm{mmol}$ ) was treated under Standard Conditions. Silica gel chromatography $\left(16 \mathrm{~g} \mathrm{SiO}_{2}, 2 \%-13 \%\right.$ EtOAc in hexanes, $1 \% / 31 \mathrm{~mL}, 25 \mathrm{~mL} / \mathrm{min}$ ) yielded $\mathbf{2 u}(106 \mathrm{mg}, 81 \%$ yield) as a clear liquid which matched the literature spectra. ${ }^{22}$

${ }^{1} \mathrm{H} \mathrm{NMR}\left(\mathrm{CDCl}_{3}, 400 \mathrm{MHz}\right): \delta 7.13(\mathrm{~d}, \mathrm{~J}=8.6 \mathrm{~Hz}, 2 \mathrm{H}), 6.81(\mathrm{~d}, \mathrm{~J}=8.6 \mathrm{~Hz}, 2 \mathrm{H}), 3.78(\mathrm{~s}$, $3 \mathrm{H}), 2.69(\mathrm{t}, \mathrm{J}=8.2 \mathrm{~Hz}, 2 \mathrm{H}), 1.22(\mathrm{~s}, 12 \mathrm{H}), 1.11(\mathrm{t}, \mathrm{J}=8.2 \mathrm{~Hz}, 2 \mathrm{H})$.

${ }^{13} \mathrm{C} \mathrm{NMR}\left(\mathrm{CDCl}_{3}, 100 \mathrm{MHz}\right): \delta 157.7,136.7,129.0,113.7,83.2,55.4,29.2,25.0$.

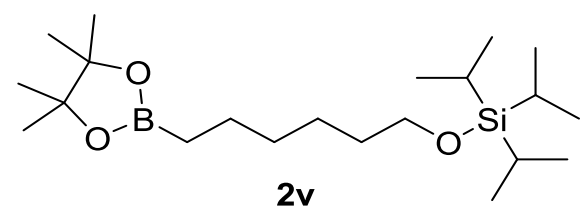

triisopropyl((6-(4,4,5,5-tetramethyl-1,3,2-dioxaborolan-2-yl)hexyl)oxy)silane (2v). (6-Chlorohexyloxy)triisopropylsilane (1v) (146.5 mg, $158.5 \mu \mathrm{L}, 0.5 \mathrm{mmol}$ ) was treated under Standard Conditions at a concentration of $0.5 \mathrm{M}$. Silica gel chromatography (5\% EtOAc in hexanes, $\mathrm{R}_{\mathrm{f}}=0.3$ ) yielded $\mathbf{2 v}(146 \mathrm{mg}, 76 \%$ yield, $78 \%$ GC yield) as a clear liquid which matched the literature spectra. ${ }^{9}$

${ }^{1} \mathrm{H} \mathrm{NMR}\left(\mathrm{CDCl}_{3}, 500 \mathrm{MHz}\right): \delta 3.65(\mathrm{t}, \mathrm{J}=6.7 \mathrm{~Hz}, 2 \mathrm{H}), 1.52(\mathrm{p}, \mathrm{J}=6.8 \mathrm{~Hz}, 2 \mathrm{H}), 1.40(\mathrm{p}, \mathrm{J}$ $=7.4 \mathrm{~Hz}, 2 \mathrm{H}), 1.37-1.26(\mathrm{~m}, 4 \mathrm{H}), 1.23(\mathrm{~s}, 12 \mathrm{H}), 1.11-1.00(\mathrm{~m}, 21 \mathrm{H}), 0.76(\mathrm{t}, \mathrm{J}=7.8$ $\mathrm{Hz}, 2 \mathrm{H})$.

${ }^{13} \mathrm{C}$ NMR $\left(\mathrm{CDCl}_{3}, 125 \mathrm{MHz}\right): \delta 83.0,63.7,33.2,32.4,25.8,25.0,24.2,18.2,12.2$. 
<smiles>CC1(C)OB(C(CCc2ccccc2)B2OC(C)(C)C(C)(C)O2)OC1(C)C</smiles>

2,2'-(3-Phenylpropane-1,1-diyl)bis(4,4,5,5-tetramethyl-1,3,2-dioxaborolane) (2w). (3,3-Dichloropropyl)benzene (1w) (49.1 $\mathrm{mg}, 0.26 \mathrm{mmol}$ ) was treated under Conditions D. Silica gel chromatography (16g SiO2, 2\%-20\% EtOAc in hexanes, $1 \% / 11 \mathrm{~mL}, 25 \mathrm{~mL} / \mathrm{min}$ ) yielded $2 \mathbf{w}(58.3 \mathrm{mg}, 60 \%$ yield) as a white solid. (3,3-Dibromopropyl)benzene (1x) (72.5 $\mathrm{mg}, 0.26 \mathrm{mmol})$ was treated under Conditions D. Silica gel chromatography (16g SiO2, 2\%-20\% EtOAc in hexanes, $1 \% / 11 \mathrm{~mL}, 25 \mathrm{~mL} / \mathrm{min}$ ) yielded $\mathbf{2 w}$ (49.9 mg, 51\% yield) as a white solid which matched the literature spectra. ${ }^{14}$

${ }^{1} \mathrm{H} \mathrm{NMR}\left(\mathrm{CDCl}_{3}, 500 \mathrm{MHz}\right): \delta 7.30-7.25(\mathrm{~m}, 2 \mathrm{H}), 7.23-7.15(\mathrm{~m}, 3 \mathrm{H}), 2.66-2.59(\mathrm{~m}$, 2H), $1.93-1.85(\mathrm{~m}, 2 \mathrm{H}), 1.27(\mathrm{~s}, 12 \mathrm{H}), 1.26(\mathrm{~s}, 12 \mathrm{H}), 0.85(\mathrm{t}, \mathrm{J}=7.9 \mathrm{~Hz}, 1 \mathrm{H})$. ${ }^{13} \mathrm{C}$ NMR $\left(\mathrm{CDCl}_{3}, 125 \mathrm{MHz}\right): \delta 143.1,128.7,128.2,125.6,83.1,38.9,28.1,25.0,24.7$.<smiles>CC1(C)OB(CB2OC(C)(C)C(C)(C)O2)OC1(C)C</smiles>

2y

Bis(4,4,5,5-tetramethyl-1,3,2-dioxaborolan-2-yl)methane (2y). Dichloromethane (1y) (42.5 mg, $32 \mu \mathrm{L}, 0.5 \mathrm{mmol}$ ) was treated under Conditions D. Silica gel chromatography (14\% EtOAc in hexanes, $\mathrm{R}_{\mathrm{f}}=0.43$ ) yielded $2 \mathrm{y}$ ( $85.3 \mathrm{mg}, 64 \%$ yield) as a colorless solid which matched the literature spectra. ${ }^{23}$

${ }^{1} \mathrm{H} \mathrm{NMR}\left(\mathrm{CDCl}_{3}, 400 \mathrm{MHz}\right): \delta 1.20(\mathrm{~s}, 24 \mathrm{H}), 0.31(\mathrm{~s}, 2 \mathrm{H})$.

${ }^{13} \mathrm{C} \mathrm{NMR}\left(\mathrm{CDCl}_{3}, 100 \mathrm{MHz}\right): \delta 83.1,24.8$. 
<smiles>CC1(C)OB(CCc2ccccc2)OC1(C)C</smiles>

SI-8

4,4,5,5-Tetramethyl-2-phenethyl-1,3,2-dioxaborolane (SI-8). (2-

Bromoethyl)benzene (1.0 g, $735 \mu \mathrm{L}, 5.4 \mathrm{mmol})$ was treated under Standard Conditions with 5 mol \% each $\mathrm{MnBr}_{2}$ and TMEDA. Silica gel chromatography (50g $\mathrm{SiO}_{2}, 0 \%-7 \%$ EtOAc in hexanes, 1\%/165mL, $40 \mathrm{~mL} / \mathrm{min}$ ) yielded SI-8 (995 mg, $79 \%$ ) as a colorless liquid.

${ }^{1} \mathrm{H} \mathrm{NMR}\left(\mathrm{CDCl}_{3}, 400 \mathrm{MHz}\right): \delta 7.31-7.21(\mathrm{~m}, 4 \mathrm{H}), 7.20-7.14(\mathrm{~m}, 1 \mathrm{H}), 2.77(\mathrm{t}, \mathrm{J}=8.2$ $\mathrm{Hz}, 2 \mathrm{H}), 1.24(\mathrm{~s}, 12 \mathrm{H}), 1.17(\mathrm{t}, \mathrm{J}=8.1 \mathrm{~Hz}, 2 \mathrm{H})$.

${ }^{13} \mathrm{C} \mathrm{NMR}\left(\mathrm{CDCl}_{3}, 100 \mathrm{MHz}\right): \delta$ 144.4, 128.1, 128.0, 125.4, 83.1, 29.9, 24.8.

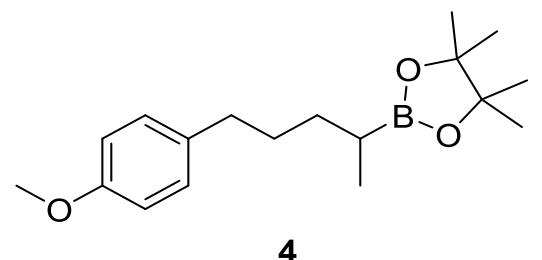

2-(5-(4-Methoxyphenyl)pentan-2-yl)-4,4,5,5-tetramethyl-1,3,2-dioxaborolane (4). $(R)$-1-(4-chloropentyl)-4-methoxybenzene ((R)-3) (35.6 mg, $0.17 \mathrm{mmol})$ was treated under Standard Conditions with 5 mol \% $\mathrm{MnBr}_{2}$ and TMEDA. Silica gel chromatography (16g SiO 2, 0\%-15\% EtOAc in hexanes, $1 \% / 22 \mathrm{~mL}, 25 \mathrm{~mL} / \mathrm{min}$ ) yielded 4 (26.8 $\mathrm{mg}, 53 \%$ yield) as a colorless liquid.

${ }^{1} \mathrm{H} \mathrm{NMR}\left(\mathrm{CDCl}_{3}, 500 \mathrm{MHz}\right): \delta 7.09(\mathrm{~d}, \mathrm{~J}=8.6 \mathrm{~Hz}, 2 \mathrm{H}), 6.81(\mathrm{~d}, \mathrm{~J}=8.6 \mathrm{~Hz}, 2 \mathrm{H}), 3.78(\mathrm{~s}$, $3 \mathrm{H}), 2.57-2.51(\mathrm{~m}, 2 \mathrm{H}), 1.66-1.55(\mathrm{~m}, 2 \mathrm{H}), 1.54-1.45(\mathrm{~m}, 1 \mathrm{H}), 1.38-1.28(\mathrm{~m}$, $1 \mathrm{H}), 1.23(\mathrm{~s}, 12 \mathrm{H}), 1.08-0.99(\mathrm{~m}, 1 \mathrm{H}), 0.99-0.93(\mathrm{~m}, 3 \mathrm{H})$.

${ }^{13} \mathrm{C}$ NMR (CDCl3, $\left.125 \mathrm{MHz}\right): \delta 157.7,135.2,129.3,113.8,83.0,55.4,35.4,33.0,31.2$, $24.9,24.9,15.6$.

HRMS (CI) Calc. for $\mathrm{C}_{18} \mathrm{H}_{29} \mathrm{BO}_{3}[\mathrm{M}+]$, 304.2204. Found: 304.2219.

FTIR (NaCl) cm-1: 2977, 2930, 2853, 1513, 1386, 1315, 1246, 1145

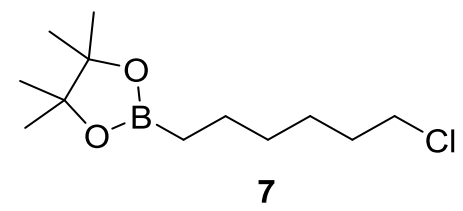

2-(6-chlorohexyl)-4,4,5,5-tetramethyl-1,3,2-dioxaborolane (7). 1-Bromo-6chlorohexane (6) (99.8 mg, $74.5 \mu \mathrm{L}, 0.5 \mathrm{mmol}$ ) was treated under Standard Conditions. Silica gel chromatography (5\% EtOAc in hexanes, $\mathrm{R}_{\mathrm{f}}=0.2$ ) yielded 7 (102.7 mg, 83\% yield) as a clear liquid which matched the literature spectra. 
1-Bromo-6-chlorohexane (6) (99.8 mg, $74.5 \mu \mathrm{L}, 0.5 \mathrm{mmol}$ ) was treated under Conditions C. Silica gel chromatography yielded 7 (49.3 mg, 40\% yield) as a clear liquid which matched the literature spectra. ${ }^{3}$

${ }^{1} \mathrm{H} \mathrm{NMR}\left(\mathrm{CDCl}_{3}, 500 \mathrm{MHz}\right): \delta 3.49(\mathrm{t}, \mathrm{J}=6.8 \mathrm{~Hz}, 2 \mathrm{H}), 1.78-1.69(\mathrm{~m}, 2 \mathrm{H}), 1.39(\mathrm{~m}$, $4 \mathrm{H}), 1.34-1.27(\mathrm{~m}, 2 \mathrm{H}), 1.22(\mathrm{~s}, 12 \mathrm{H}), 0.75(\mathrm{t}, \mathrm{J}=7.7 \mathrm{~Hz}, 2 \mathrm{H})$.

${ }^{13} \mathrm{C}$ NMR ( $\left.\mathrm{CDCl}_{3}, 125 \mathrm{MHz}\right): \delta$ 83.0, 45.2, 32.6, 31.6, 26.7, 24.9, 23.9.

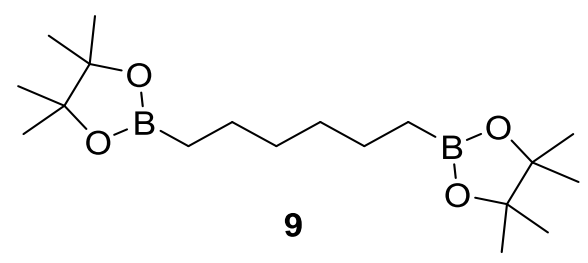

1,6-bis(4,4,5,5-tetramethyl-1,3,2-dioxaborolan-2-yl)hexane (9). 1-Bromo-6chlorohexane (6) (99.8 mg, $74.5 \mu \mathrm{L}, 0.5 \mathrm{mmol}$ ) was treated under Standard Conditions. Silica gel chromatography (5\% EtOAc in hexanes then 10\% EtOAc in hexanes, $\mathrm{Rf}_{\mathrm{f}}=0.3$ ) yielded 9 ( $6.7 \mathrm{mg}, 4 \%$ yield $)$ as a clear liquid.

1-Bromo-6-chlorohexane (6) (99.8 mg, $74.5 \mu \mathrm{L}, 0.5 \mathrm{mmol})$ was treated under Conditions C. Silica gel chromatography yielded 9 ( $72.9 \mathrm{mg}, 43 \%$ yield) as a clear liquid.

To access 9 directly in high yield, 1,6-dibromohexane (122 mg, $77 \mu \mathrm{L}, 0.5 \mathrm{mmol}$ ) was treated under Conditions D. Silica gel chromatography (20\% EtOAc in hexanes, $\mathrm{R}_{\mathrm{f}}=0.6$ ) yielded 9 ( $96.1 \mathrm{mg}, 57 \%$ yield) as a clear liquid which matched the literature spectra. ${ }^{3}$

${ }^{1} \mathrm{H} \mathrm{NMR}\left(\mathrm{CDCl}_{3}, 400 \mathrm{MHz}\right): \delta 1.41-1.31(\mathrm{~m}, 4 \mathrm{H}), 1.28-1.23(\mathrm{~m}, 4 \mathrm{H}), 1.21(\mathrm{~s}, 24 \mathrm{H})$, $0.72(\mathrm{t}, \mathrm{J}=7.7 \mathrm{~Hz}, 4 \mathrm{H})$.

${ }^{13} \mathrm{C}$ NMR $\left(\mathrm{CDCl}_{3}, 100 \mathrm{MHz}\right): \delta 82.9,32.3,24.9,24.1$. 


\section{References.}

(1) Pangborn, A. B.; Giardello, M. A.; Grubbs, R. H.; Rosen, R. K.; Timmers, F. J. Organometallics 1996, 1518.

(2) Lipani, Z.; Catalano, M. R.; Rossi, P.; Paoli, P.; Malandrino, G. Chem. Vap. Depos. 2013, 19, 22.

(3) Atack, T. C.; Lecker, R. M.; Cook, S. P. J. Am. Chem. Soc. 2014, 136, 9521.

(4) Denton, R. M.; An, J.; Adeniran, B.; Blake, A. J.; Lewis, W.; Poulton, A. M. J. Org. Chem. 2011, 76, 6749.

(5) Guziec, F. S.; Wei, D. C. J. Org. Chem. 1992, 57, 3772.

(6) Gao, K.; Yamakawa, T.; Yoshikai, N. Synthesis. 2014, 46, 2024.

(7) Mohan, A.; Ramkumar, V.; Sankararaman, S. J. Organomet. Chem. 2015, 799$800,115$.

(8) Kropp, P. J.; Fryxell, G. E.; Tubergen, M. W.; Hager, M. W.; Harris Jr., G. D.; McDermott Jr., T. P.; Tornero-Velez, R. J. Am. Chem. Soc. 1991, 113, 7300.

(9) Yang, C.-T.; Zhang, Z.-Q.; Tajuddin, H.; Wu, C.-C.; Liang, J.; Liu, J.-H.; Fu, Y.; Czyzewska, M.; Steel, P. G.; Marder, T. B.; Liu, L. Angew. Chem. Int. Ed. Engl. 2012, 51, 528.

(10) Miura, T.; Nakashima, K.; Tada, N.; Itoh, A. Chem. Comm. 2011, 47, 1875.

(11) Ochiai, M.; Yoshimura, A.; Okubo, T.; Saito, M.; Miyamoto, K. Org. Lett. 2011, 9.

(12) Yamada, K.; Yoshida, S.; Fujita, H.; Kitamura, M.; Kunishima, M. European J. Org. Chem. 2015, 2015, 7997.

(13) Aghapour, G.; Afzali, A. Synth. Commun. 2008, 38, 4023.

(14) Hong, K.; Liu, X.; Morken, J. P. J. Am. Chem. Soc. 2014, 2.

(15) Jefferies, L. R.; Cook, S. P. Org. Lett. 2014, 16, 2026.

(16) Joshi-Pangu, A.; Ma, X.; Diane, M.; Iqbal, S.; Kribs, R. J.; Huang, R.; Wang, C.Y.; Biscoe, M. R. J. Org. Chem. 2012, 77, 6629.

(17) Dudnik, A. S.; Fu, G. C. J. Am. Chem. Soc. 2012, 134, 10693.

(18) Ito, H.; Kubota, K. Org. Lett. 2012, 14, 890.

(19) Nakamura, M.; Hara, K.; Hatakeyama, T.; Nakamura, E. Org. Lett. 2001, 3, 3137.

(20) Murata, M.; Kawakita, K.; Asana, T.; Watanabe, S.; Masuda, Y. Bull. Chem. Soc. Jpn. 2002, 75, 825.

(21) Kubota, K.; Yamamoto, E.; Ito, H. J. Am. Chem. Soc. 2013, 135, 2635.

(22) Wen, Y.; Xie, J.; Deng, C.; Li, C. J. Org. Chem. 2015, 80, 4142.

(23) Sun, C.; Potter, B.; Morken, J. P. J. Am. Chem. Soc. 2014, 136, 6534. 
NMR Spectra.

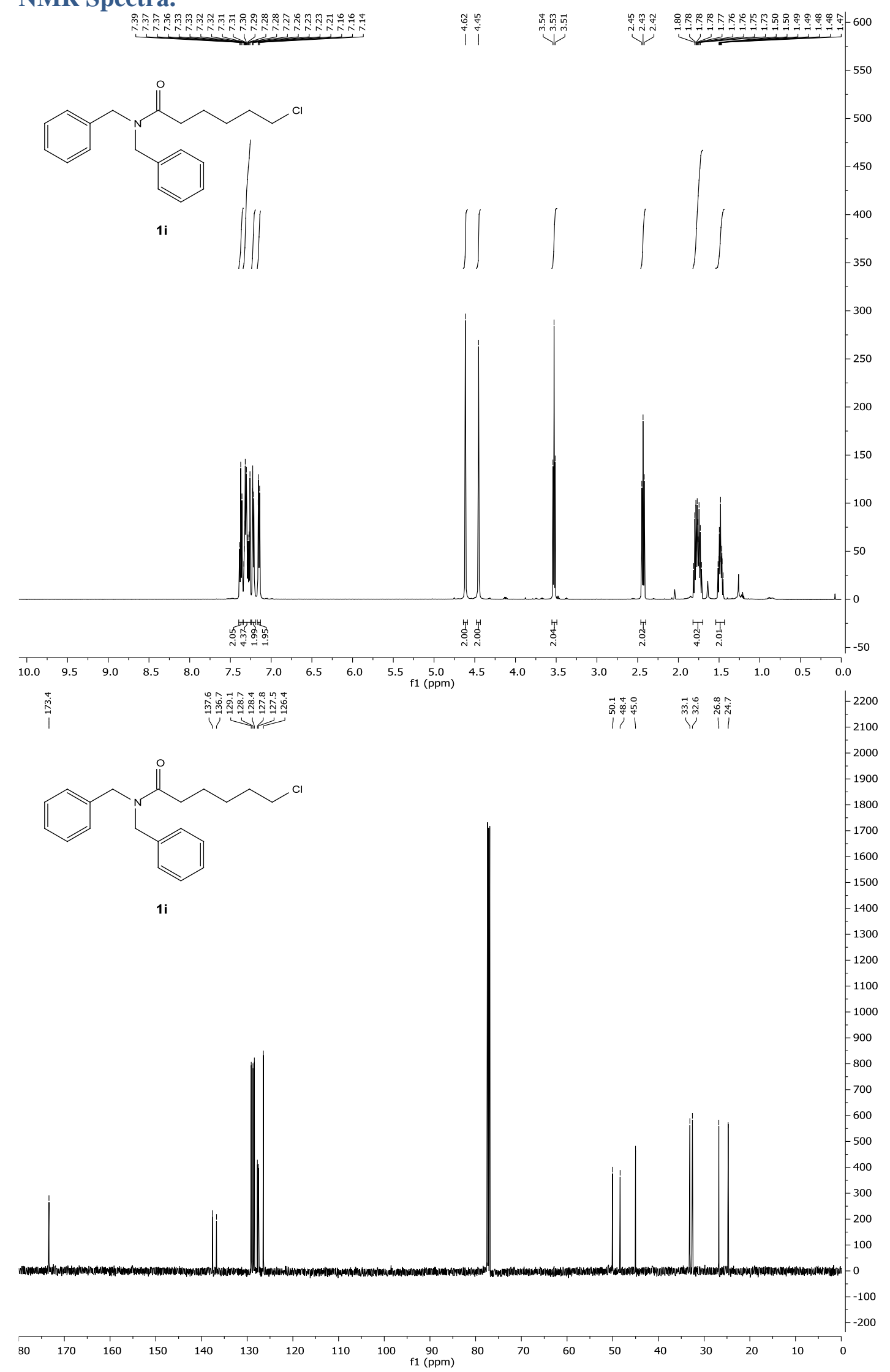

SI-42 


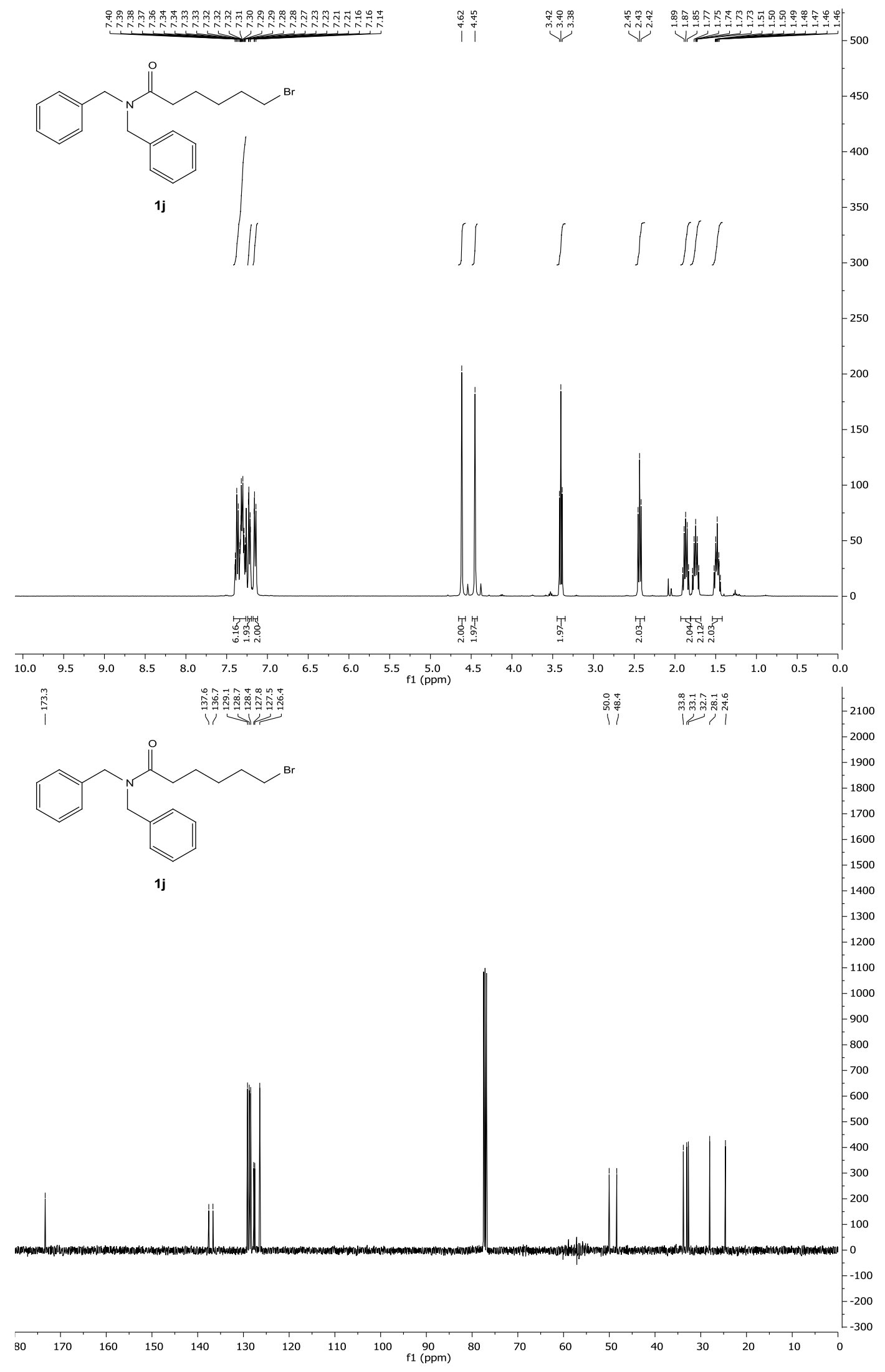




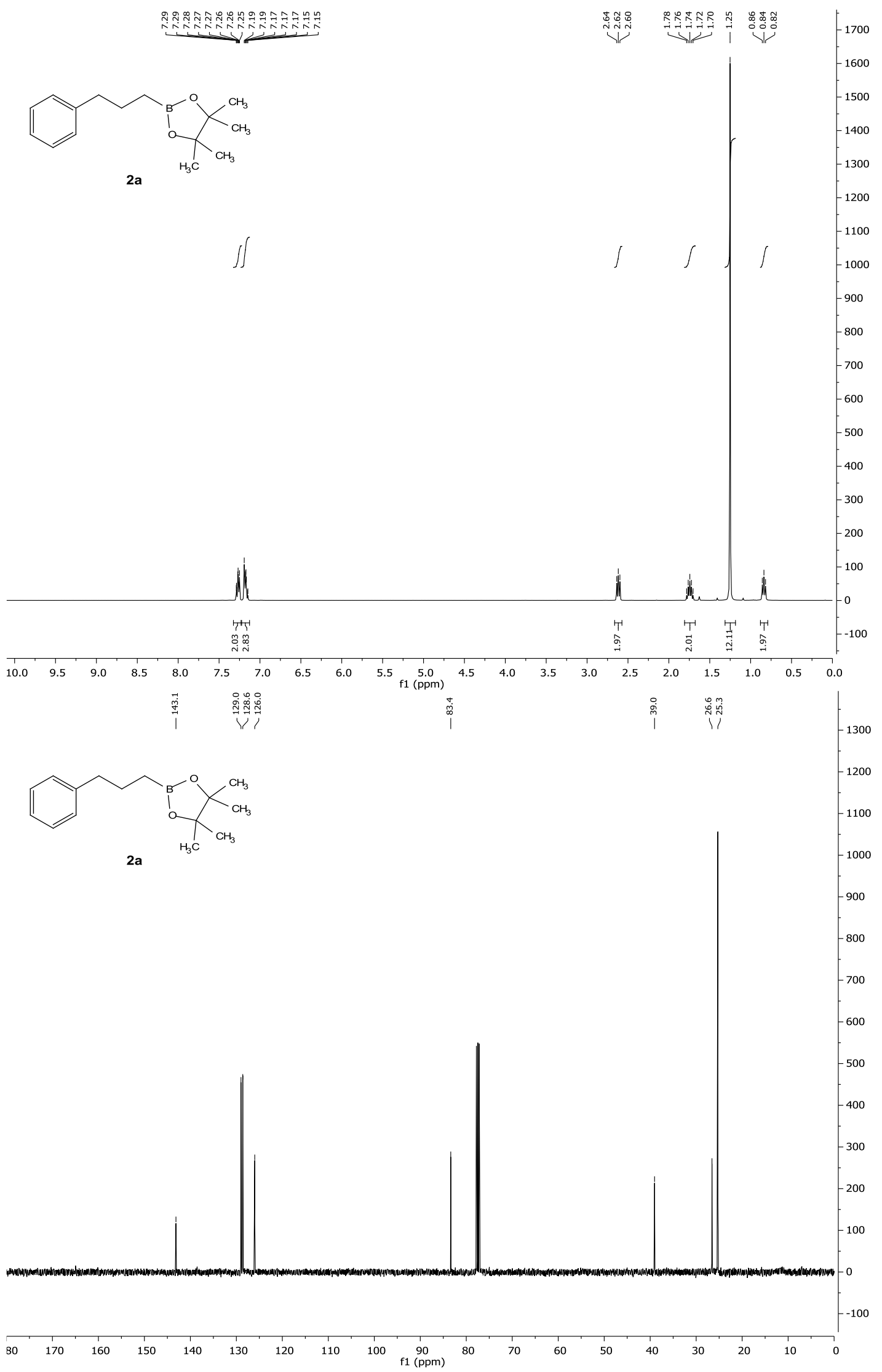




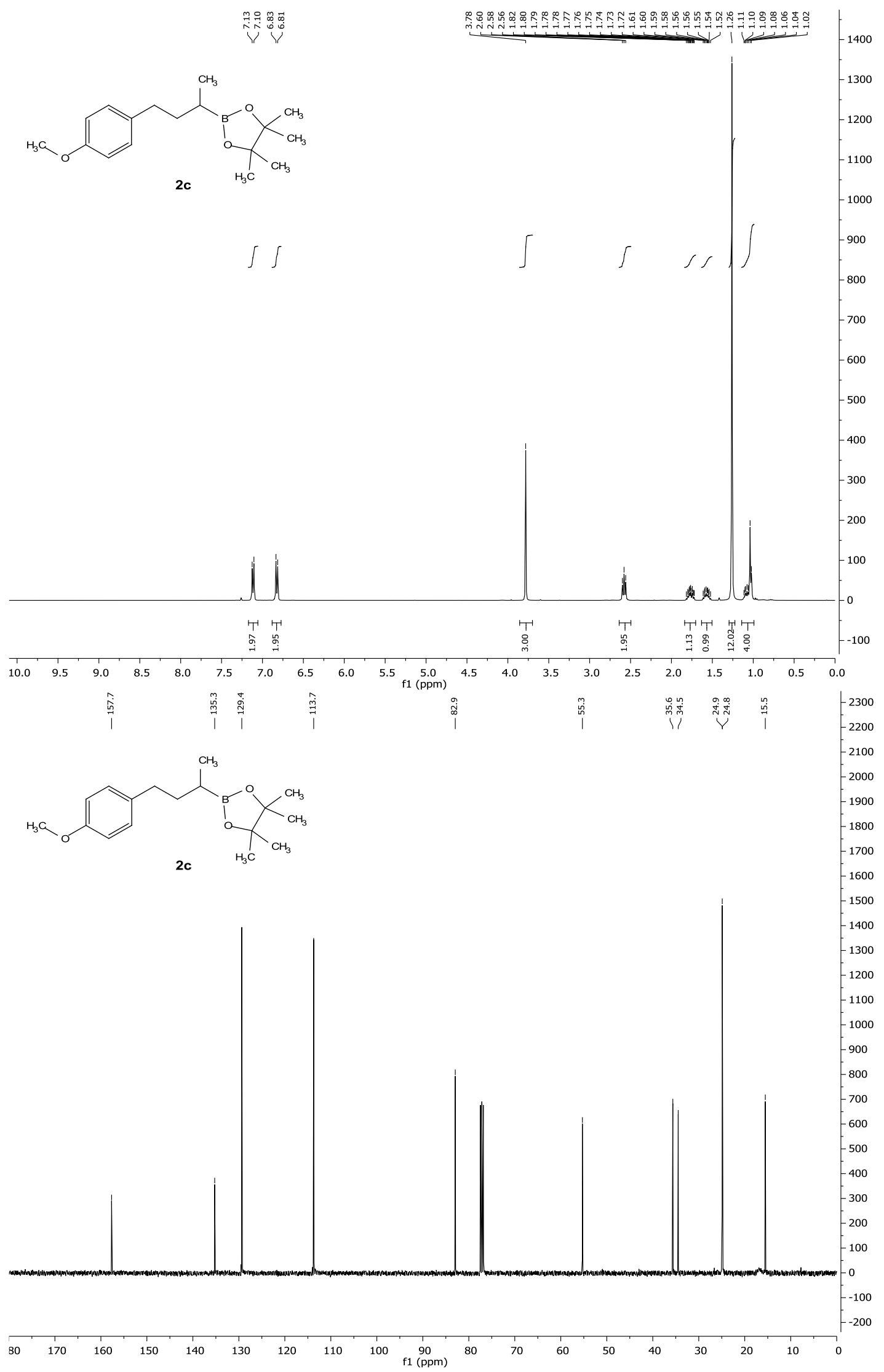




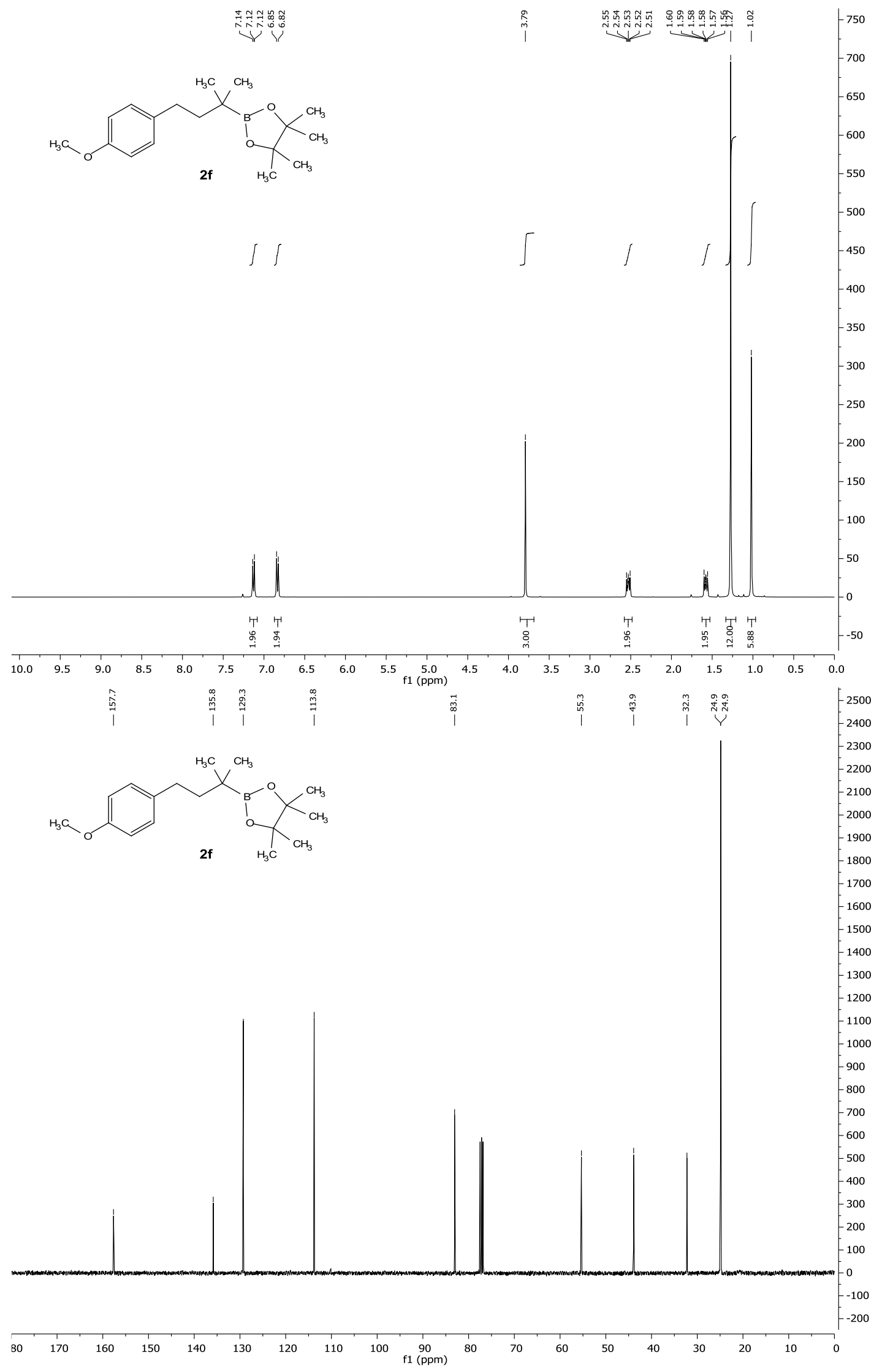




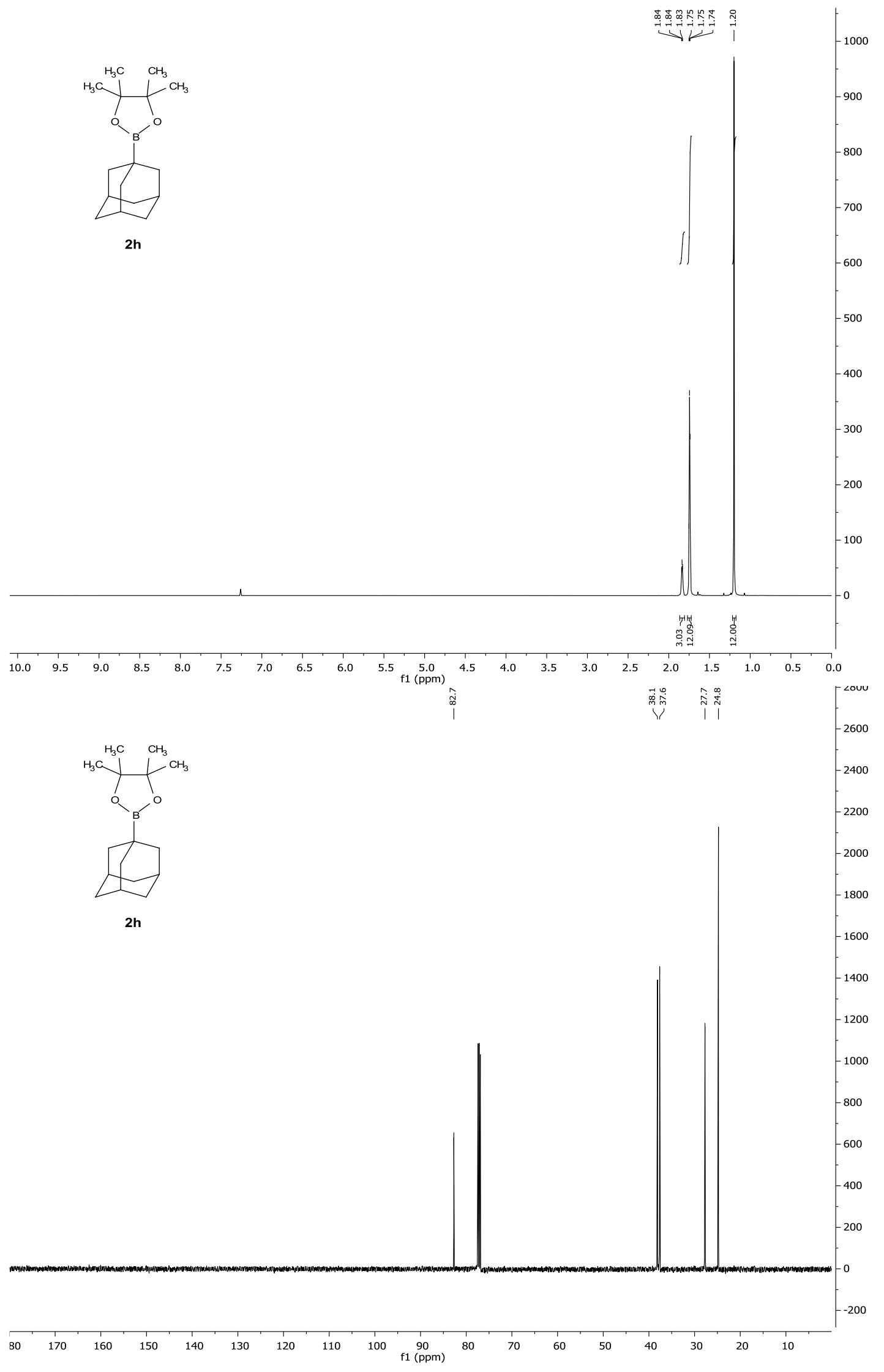




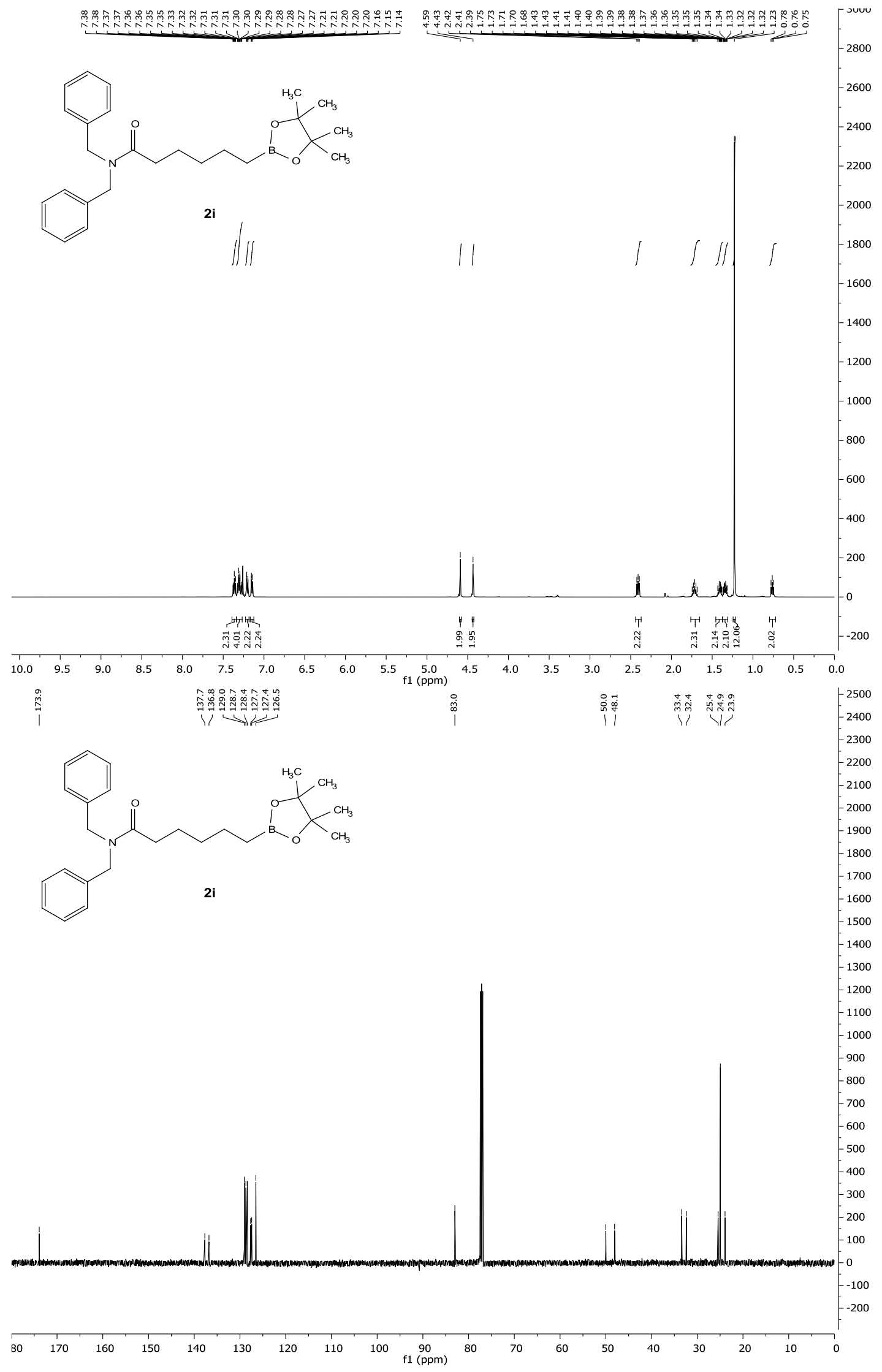




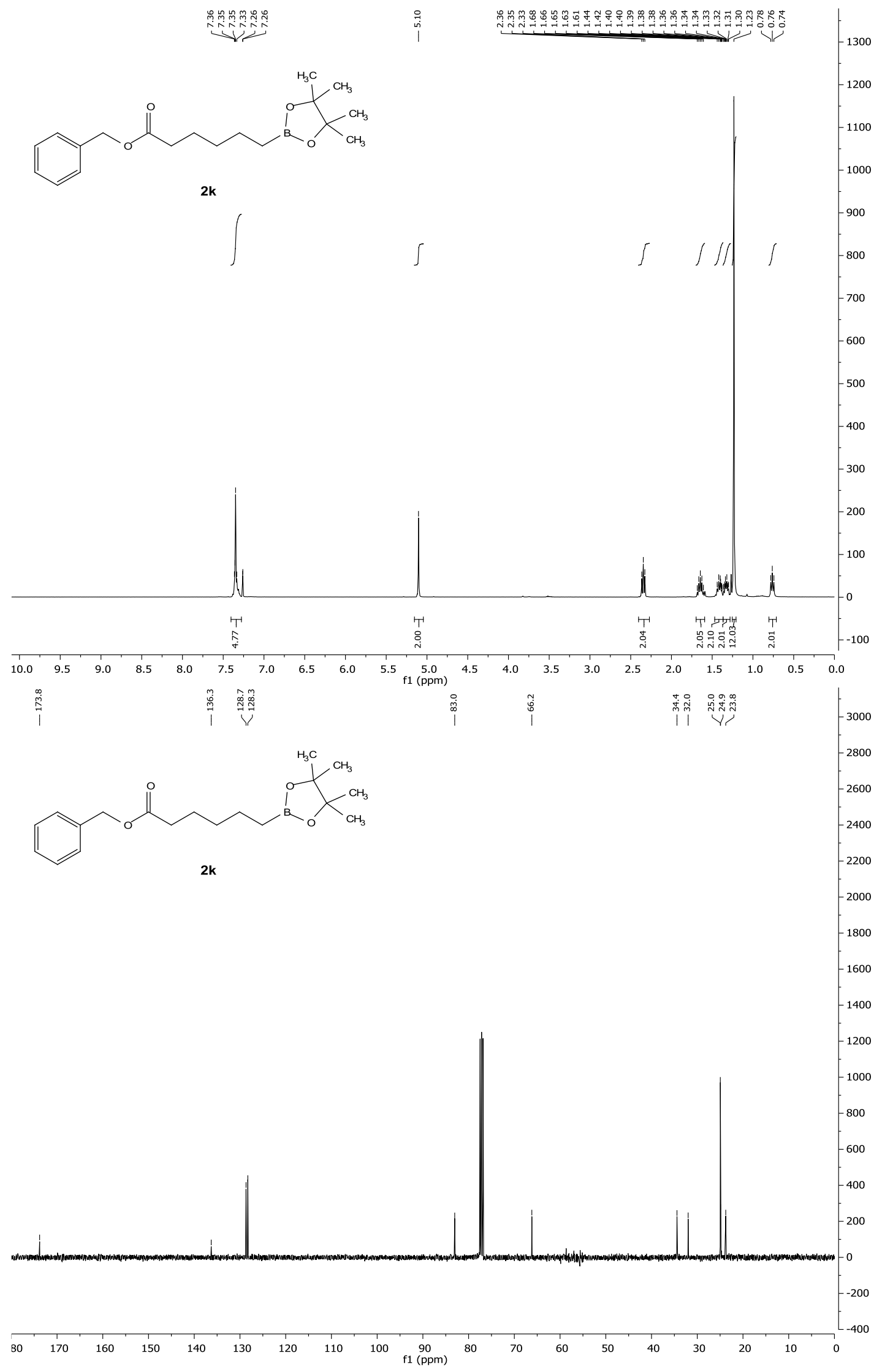




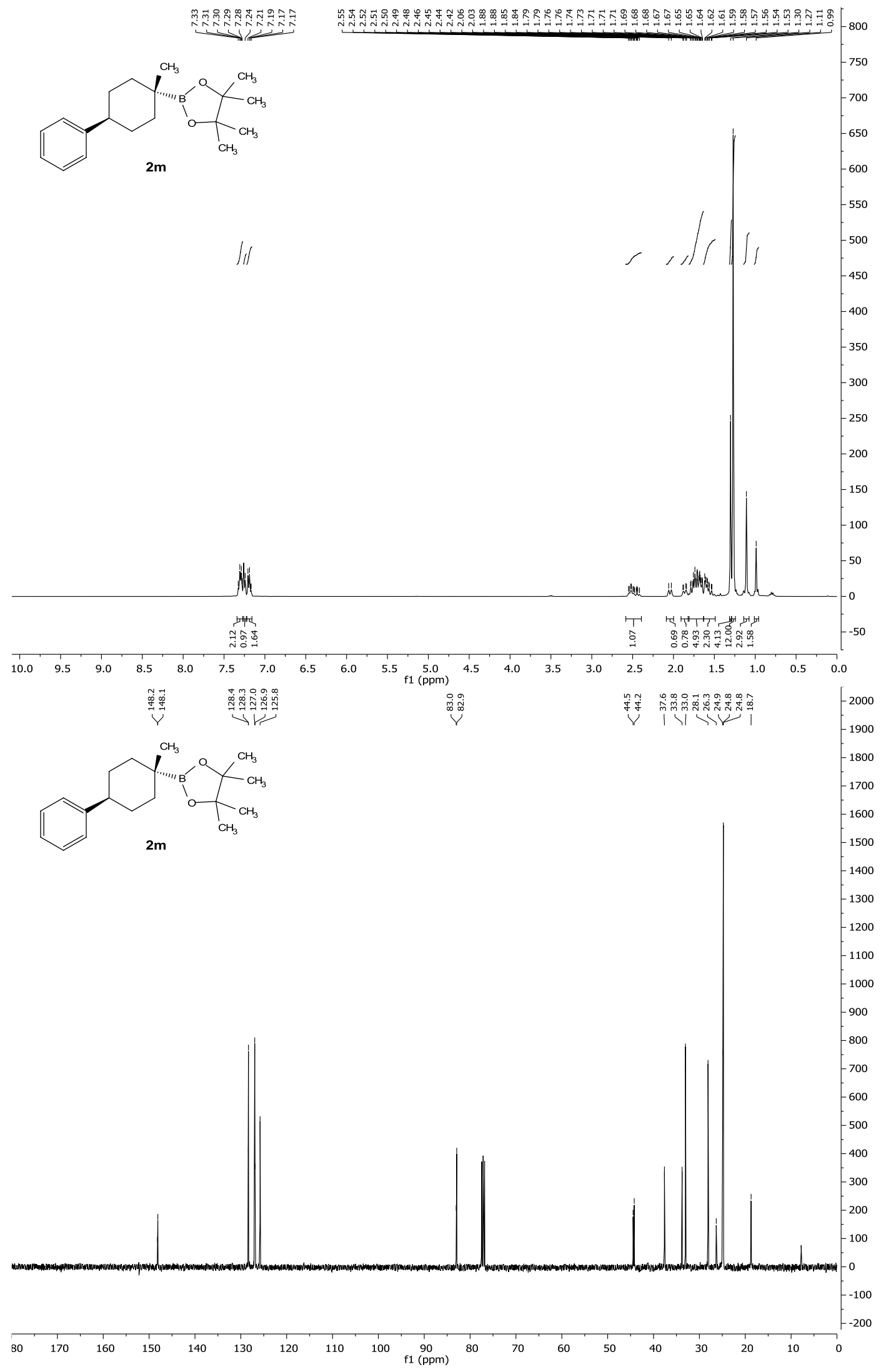




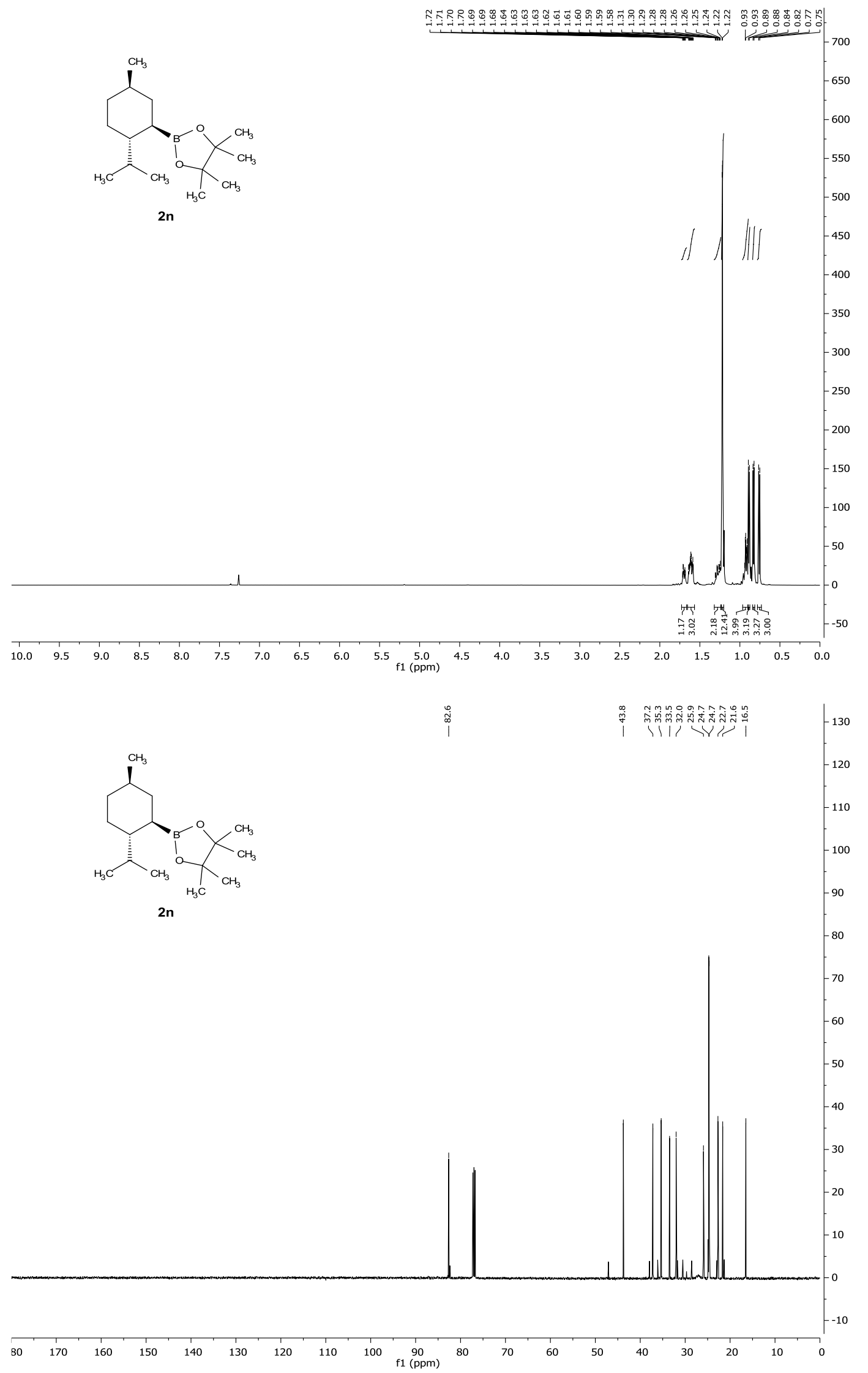

SI-51 


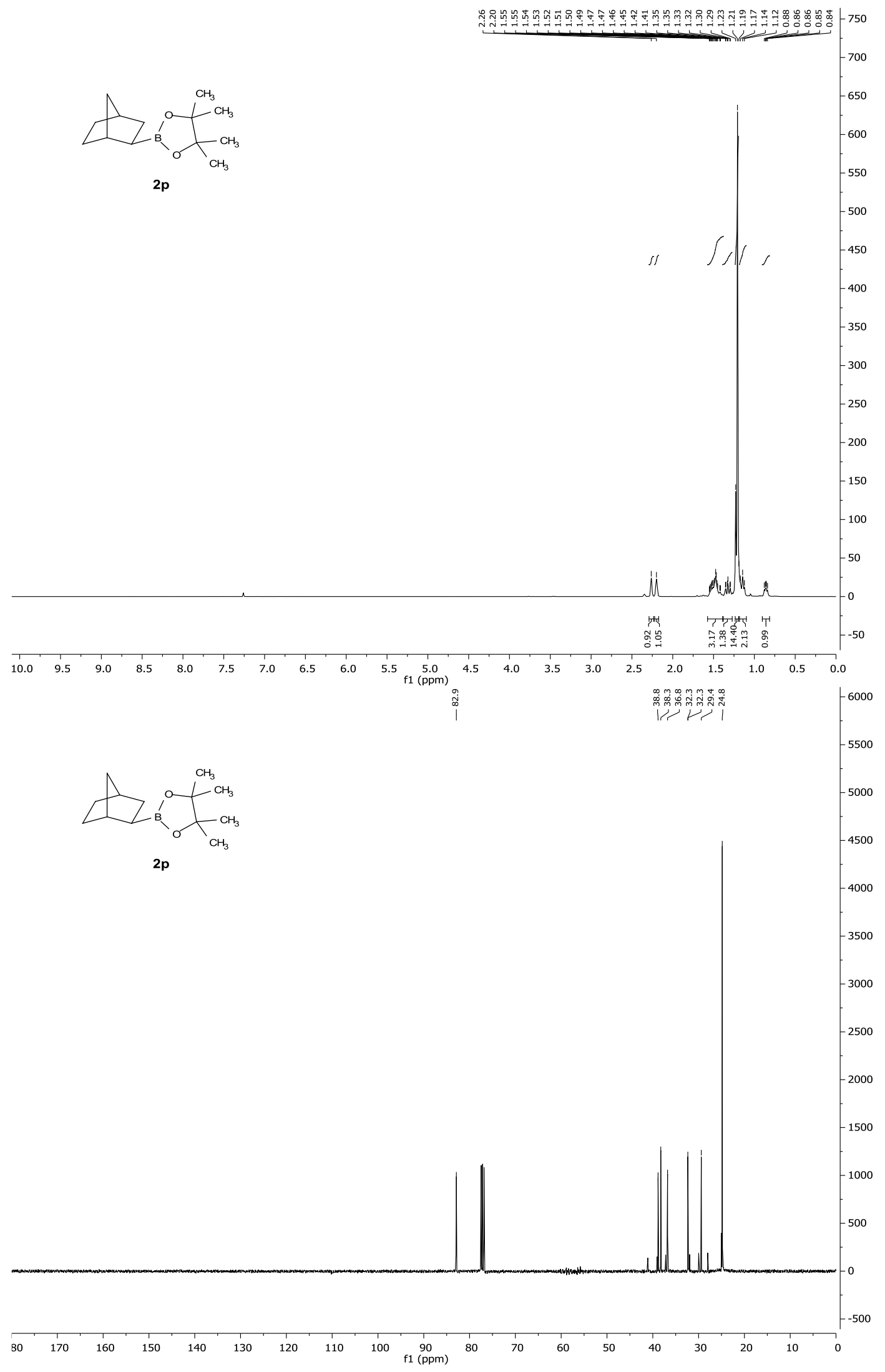

SI-52 


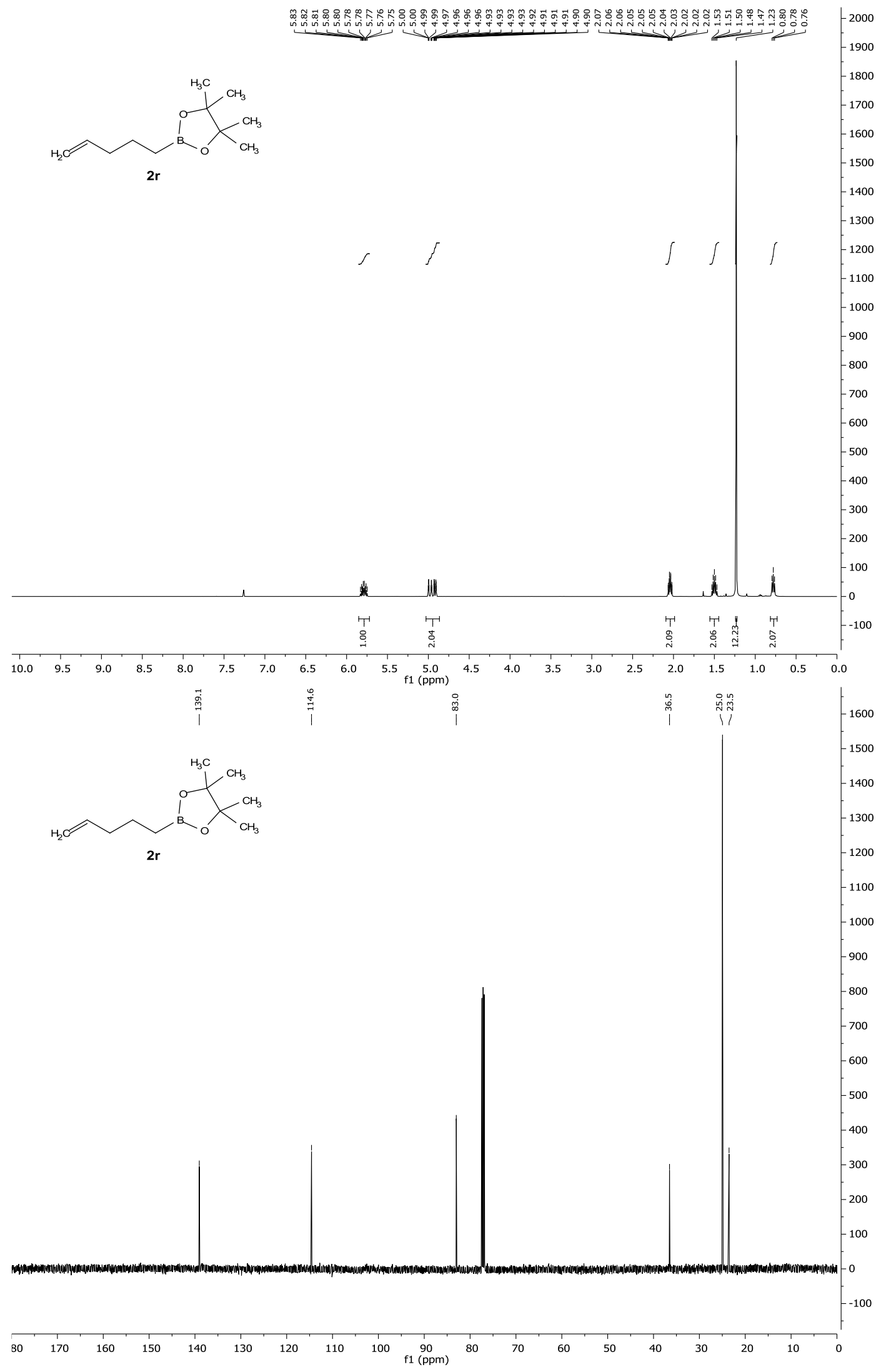

SI-53 


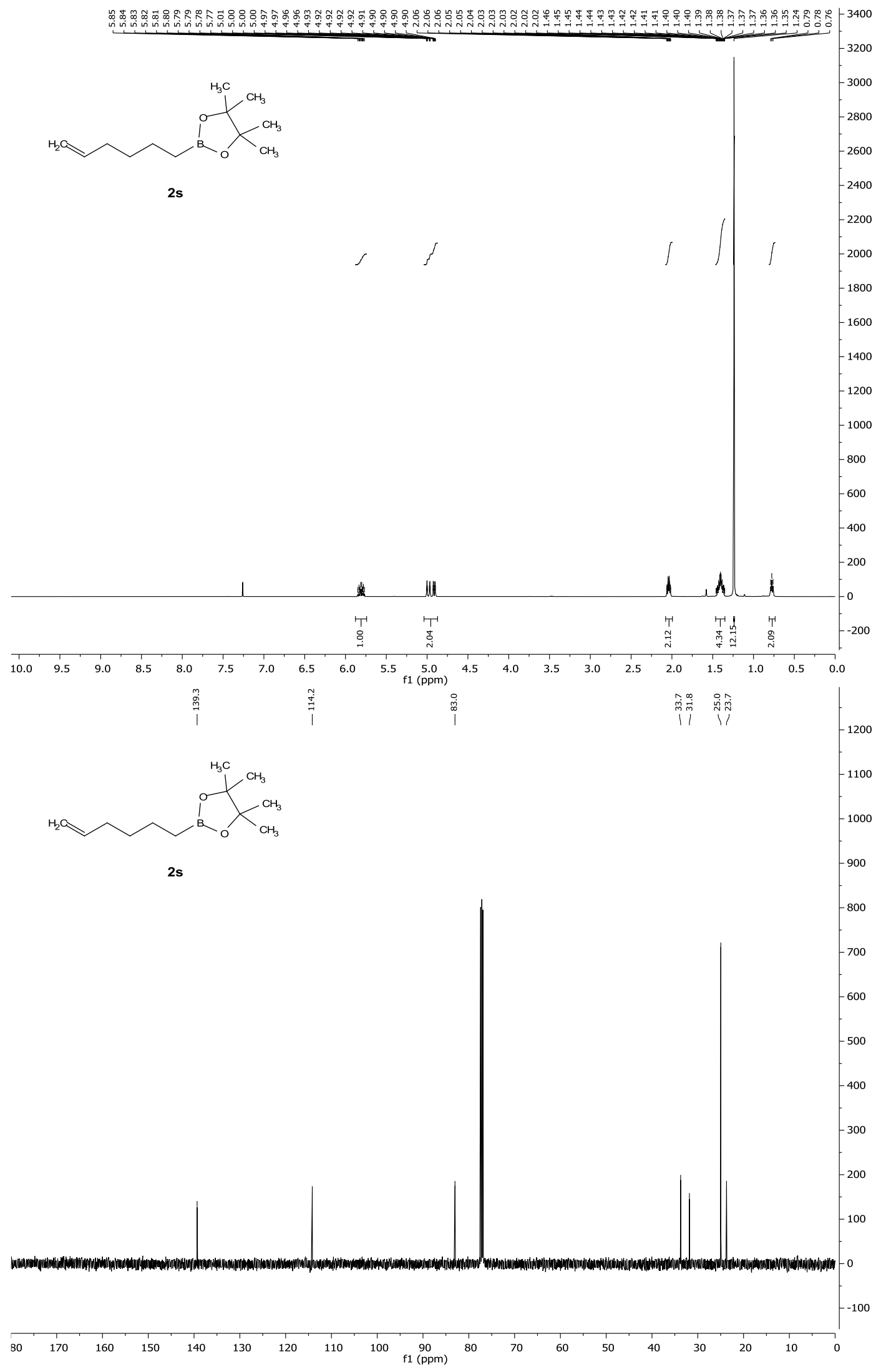




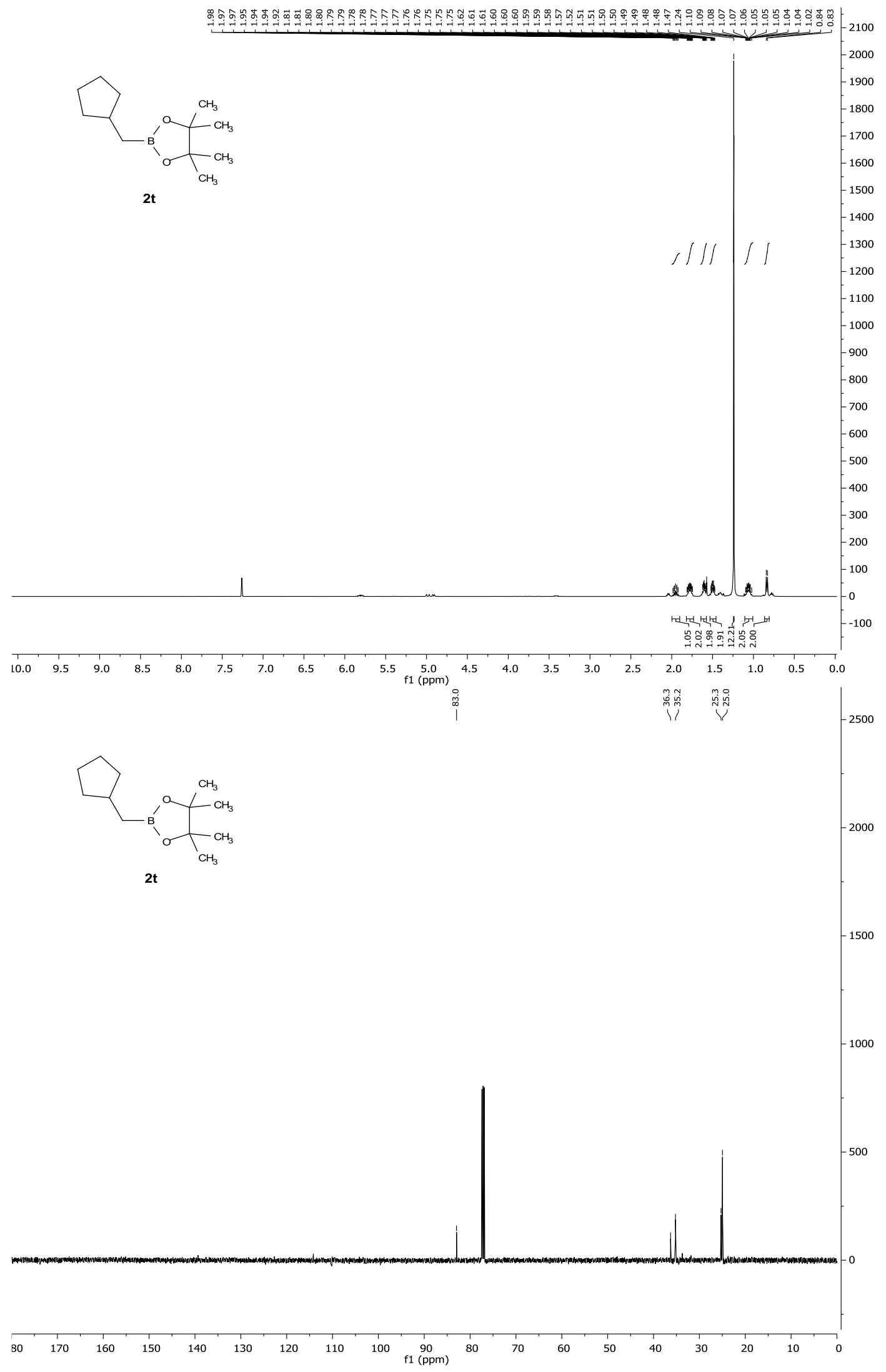

SI-55 


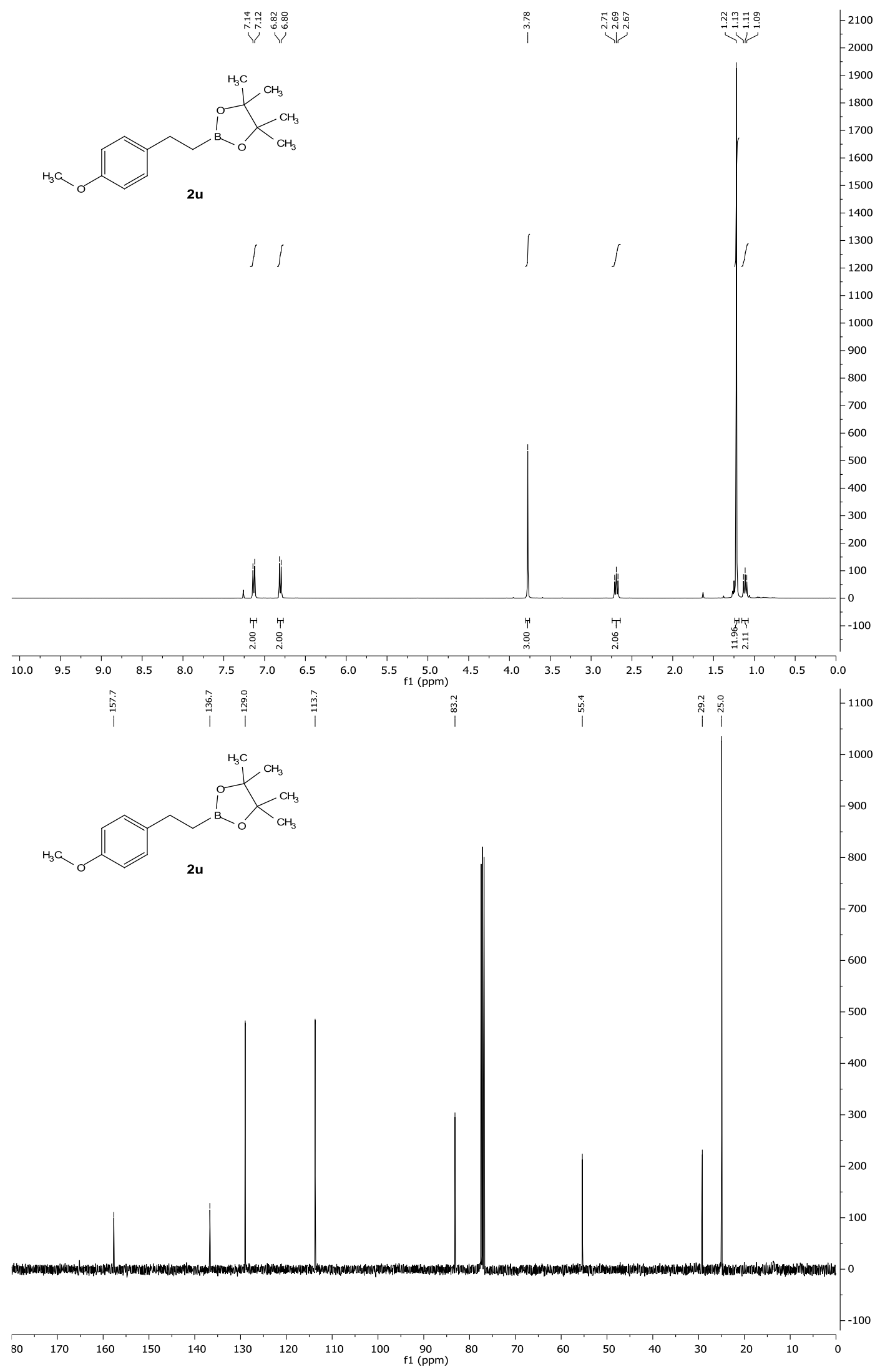




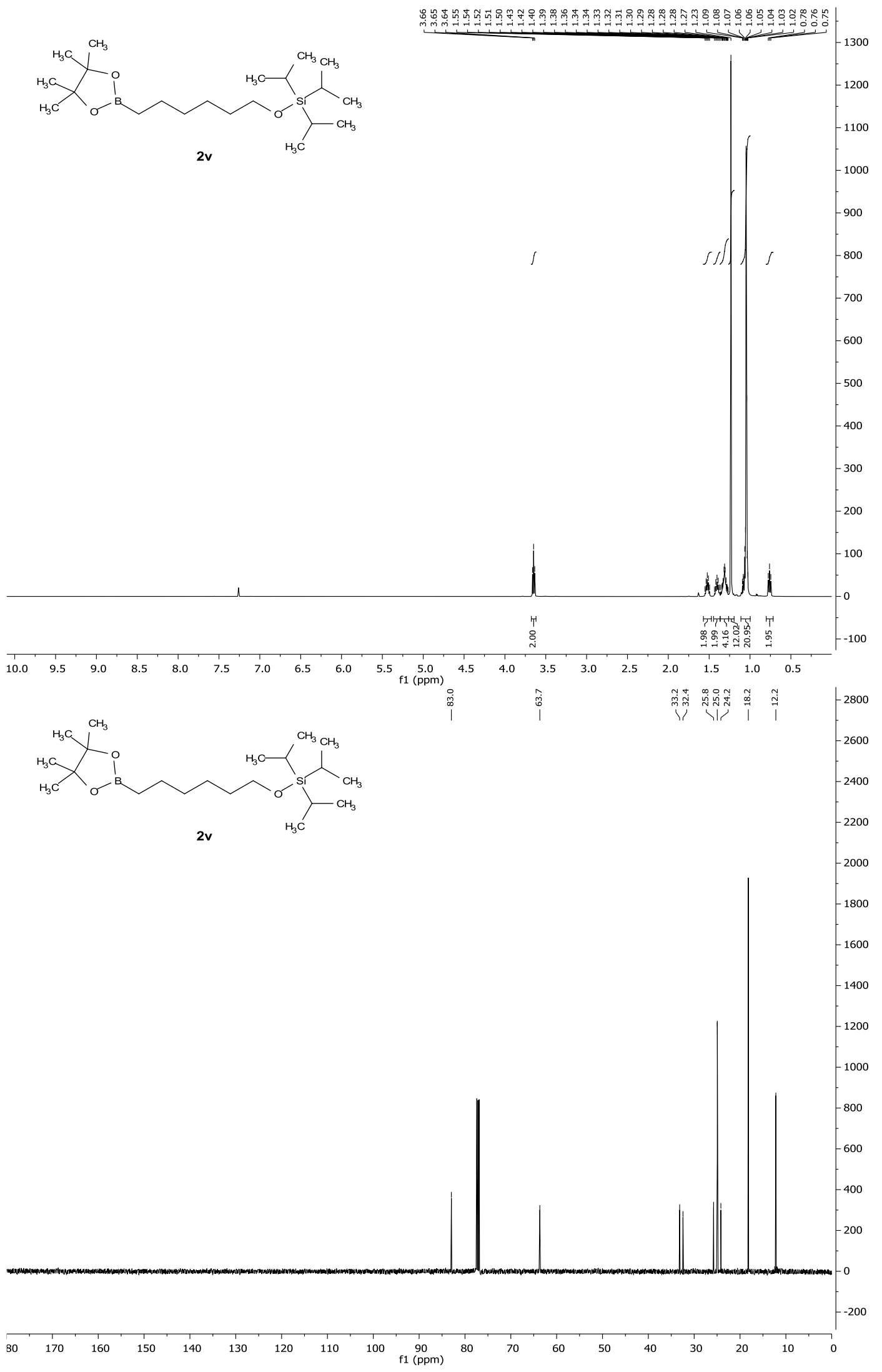




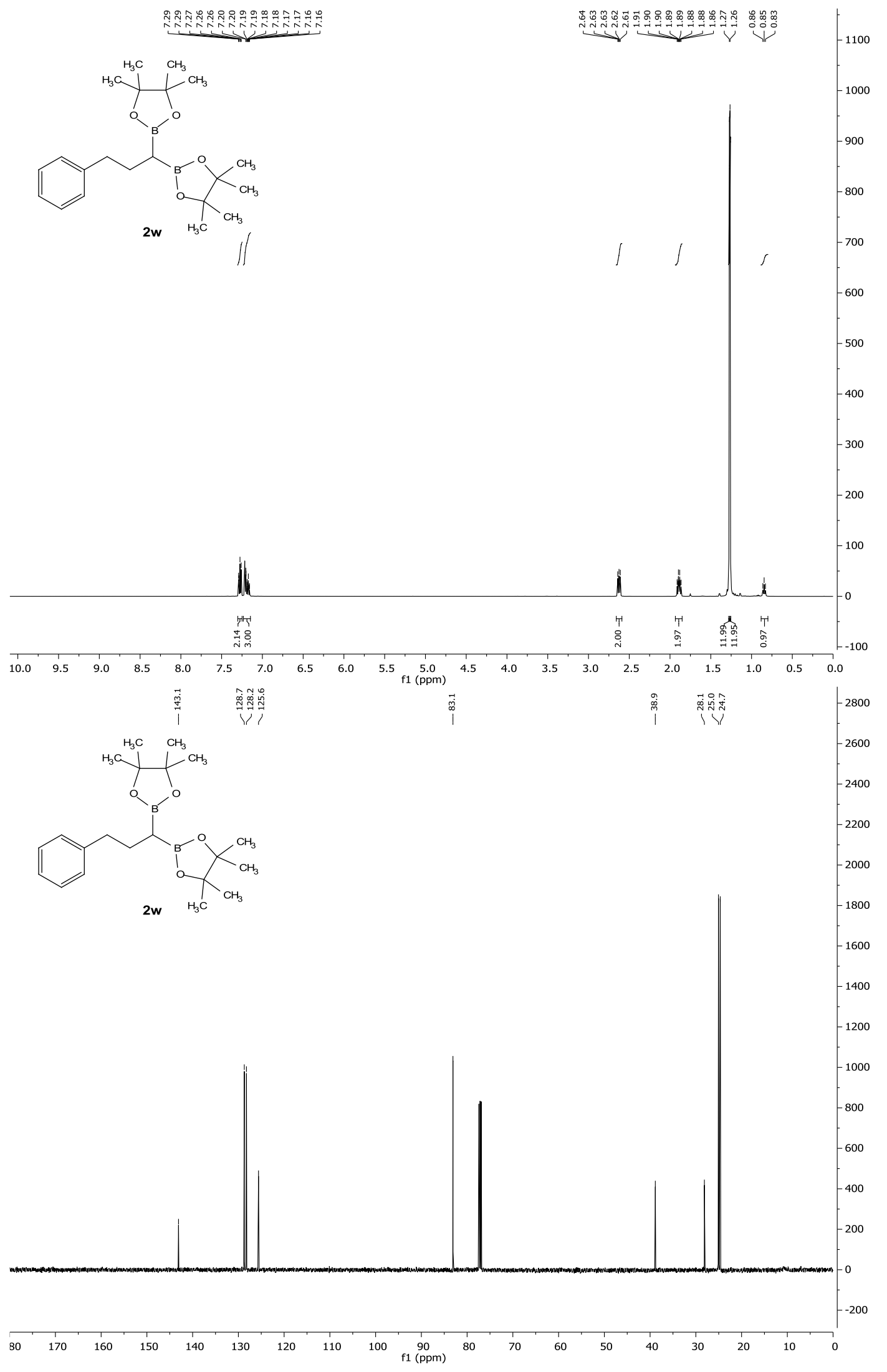




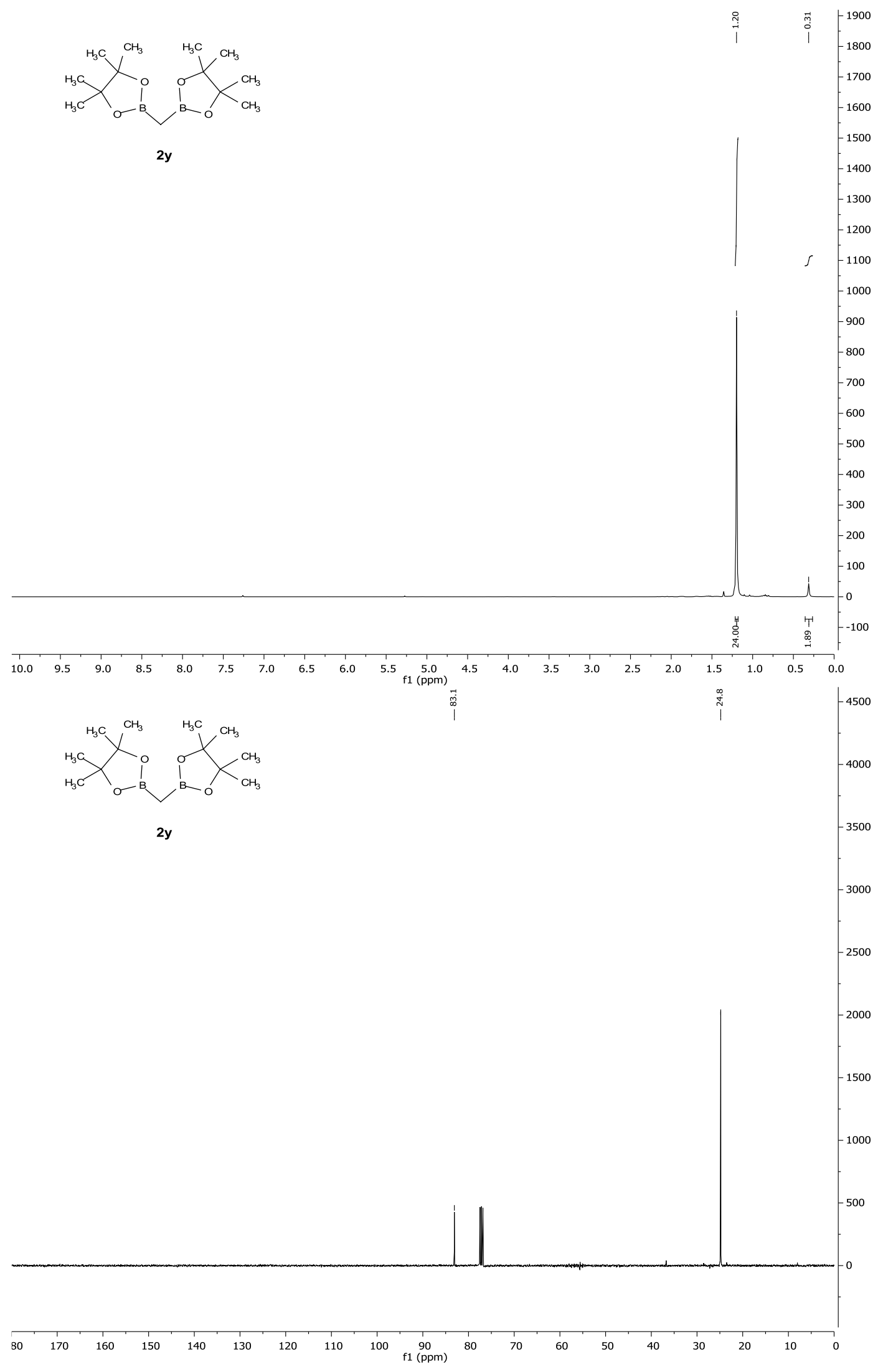

SI-59 


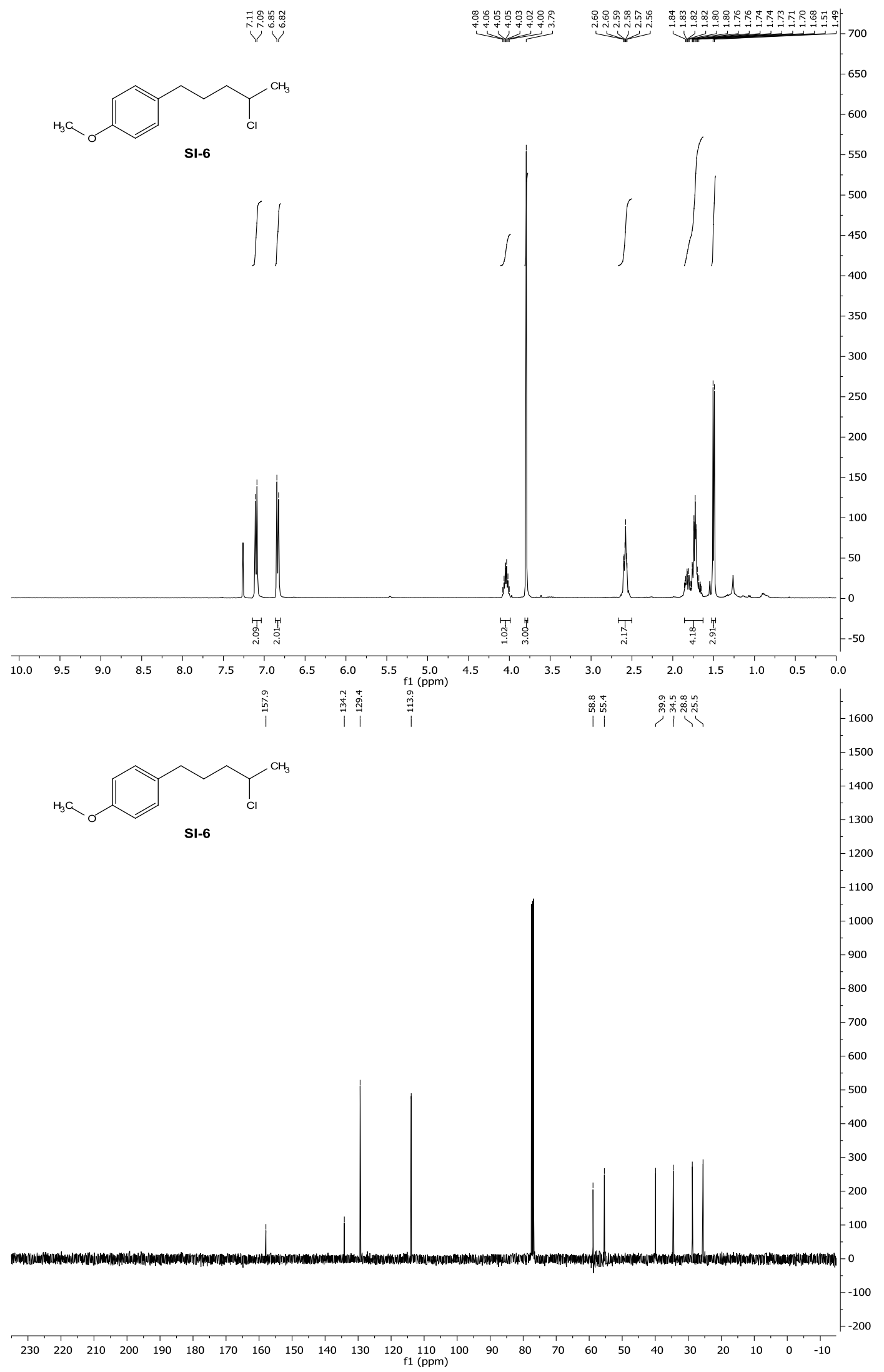




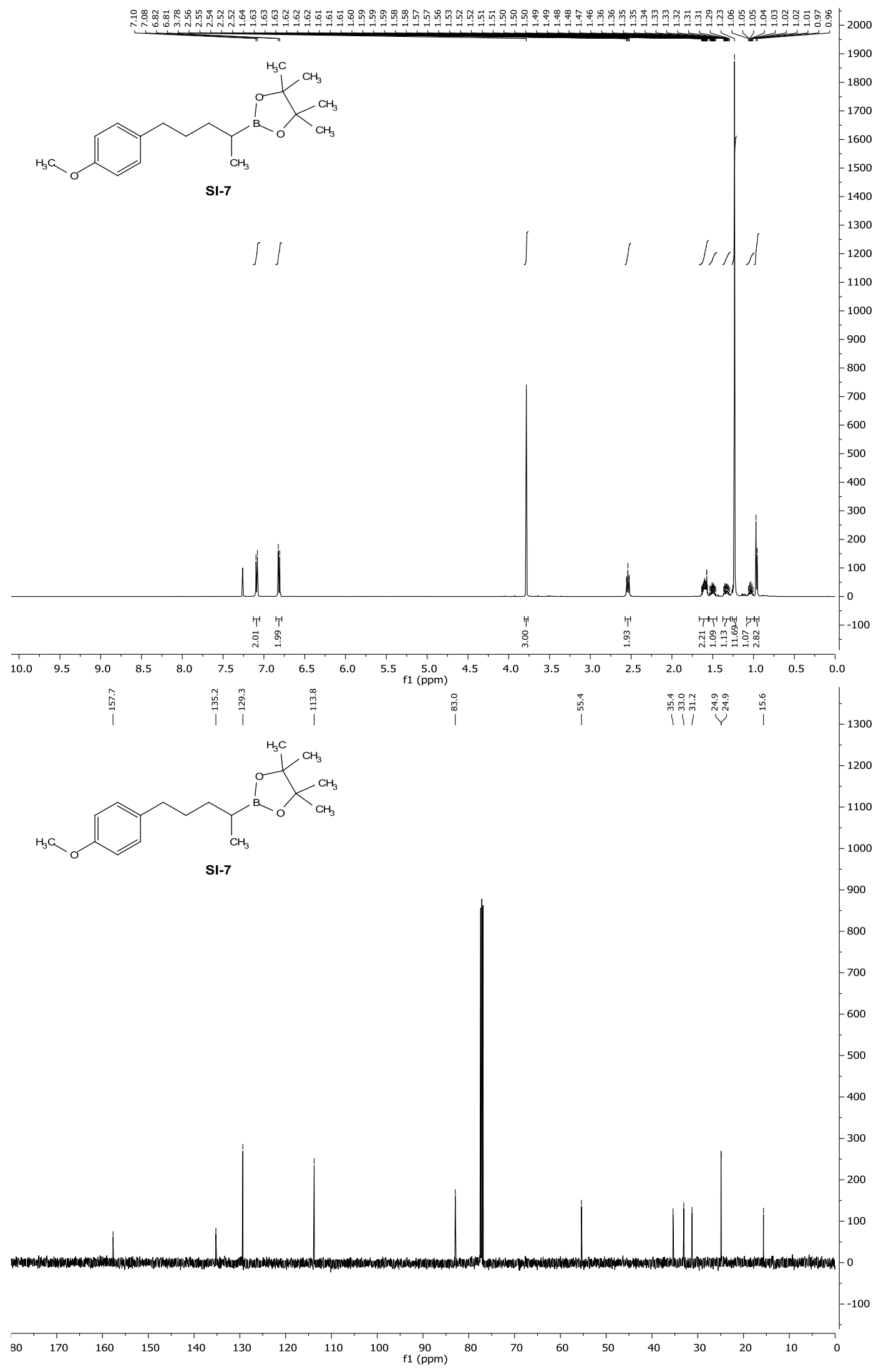




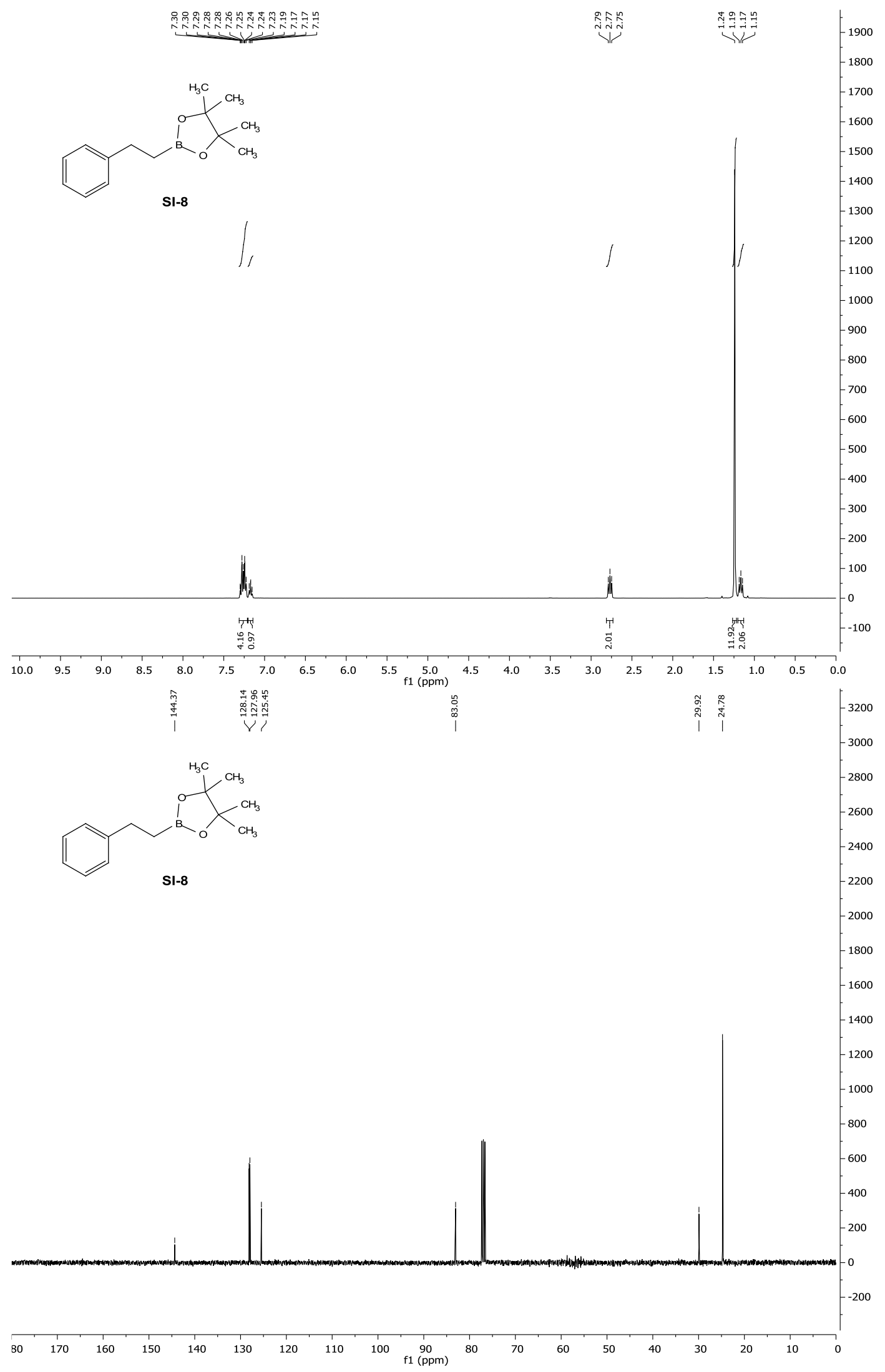




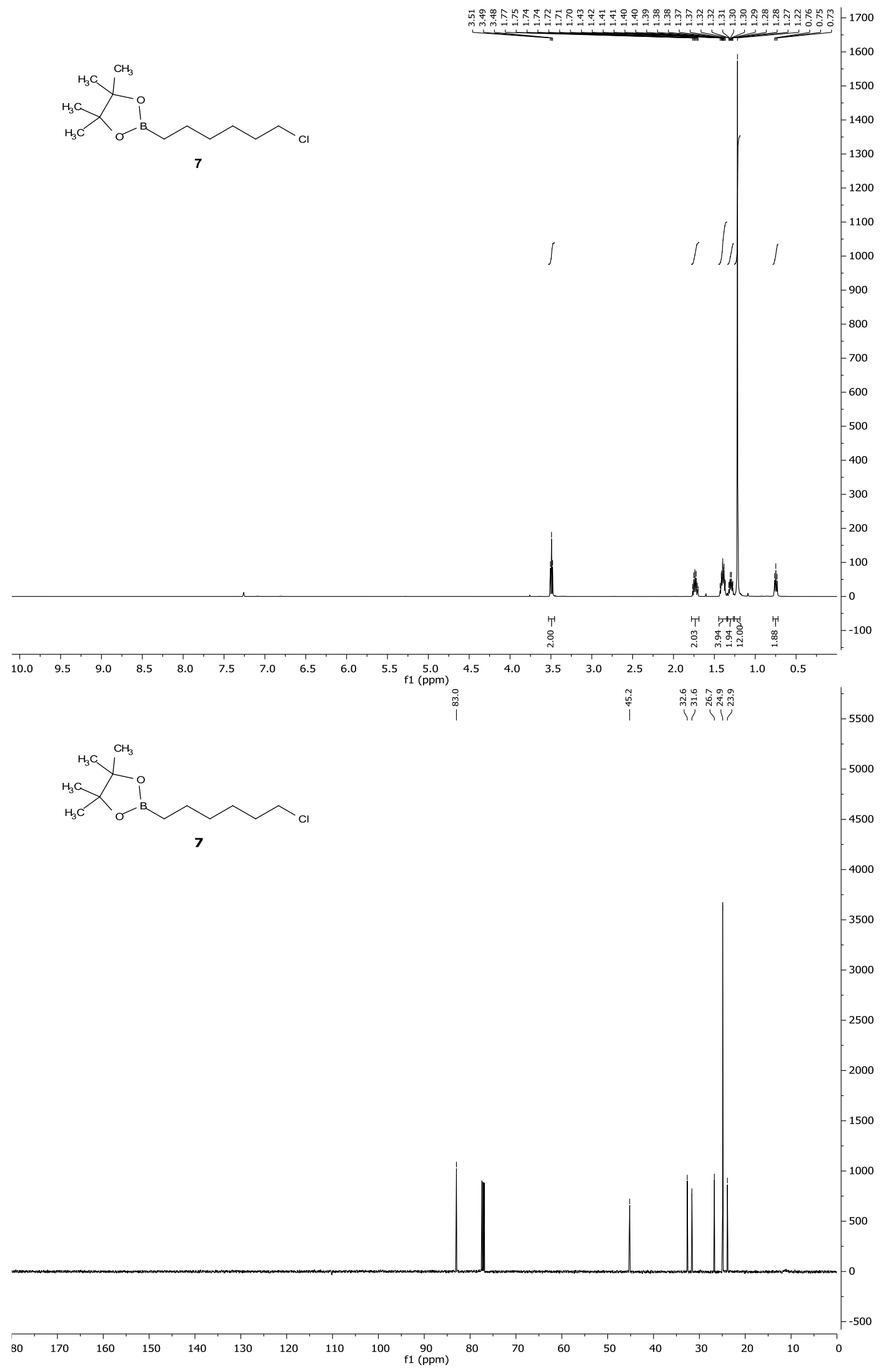

SI-63 

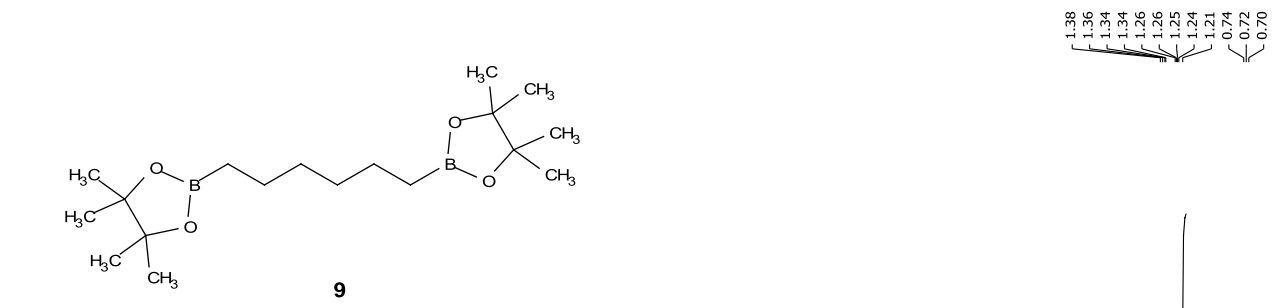

\begin{tabular}{l}
1700 \\
1600 \\
-1500 \\
-1400 \\
-1300 \\
-1200 \\
-1100 \\
-1000 \\
-900 \\
-800 \\
-700 \\
-600 \\
-500 \\
-400 \\
-300 \\
-200 \\
-100 \\
-0 \\
\hline
\end{tabular}
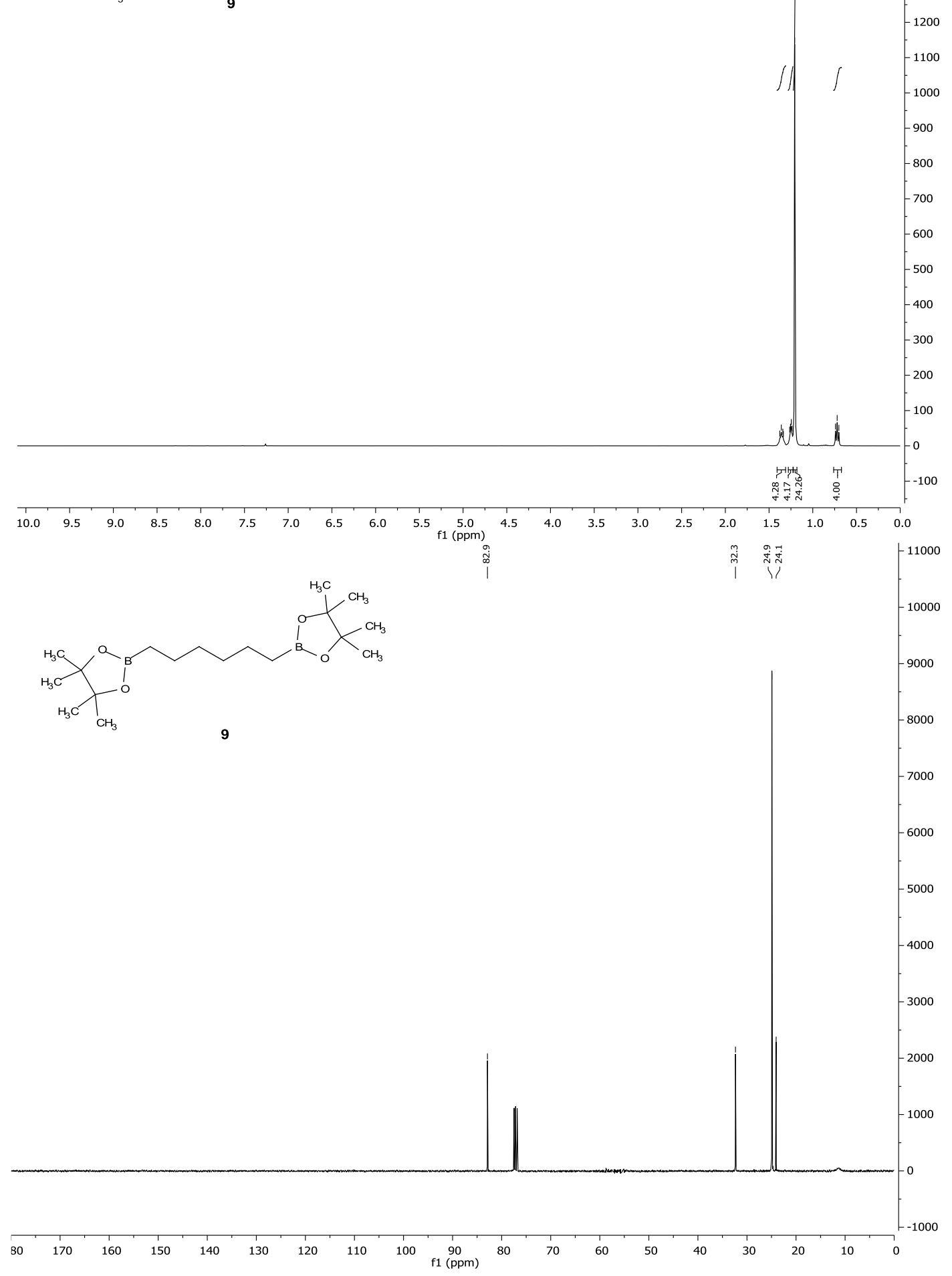


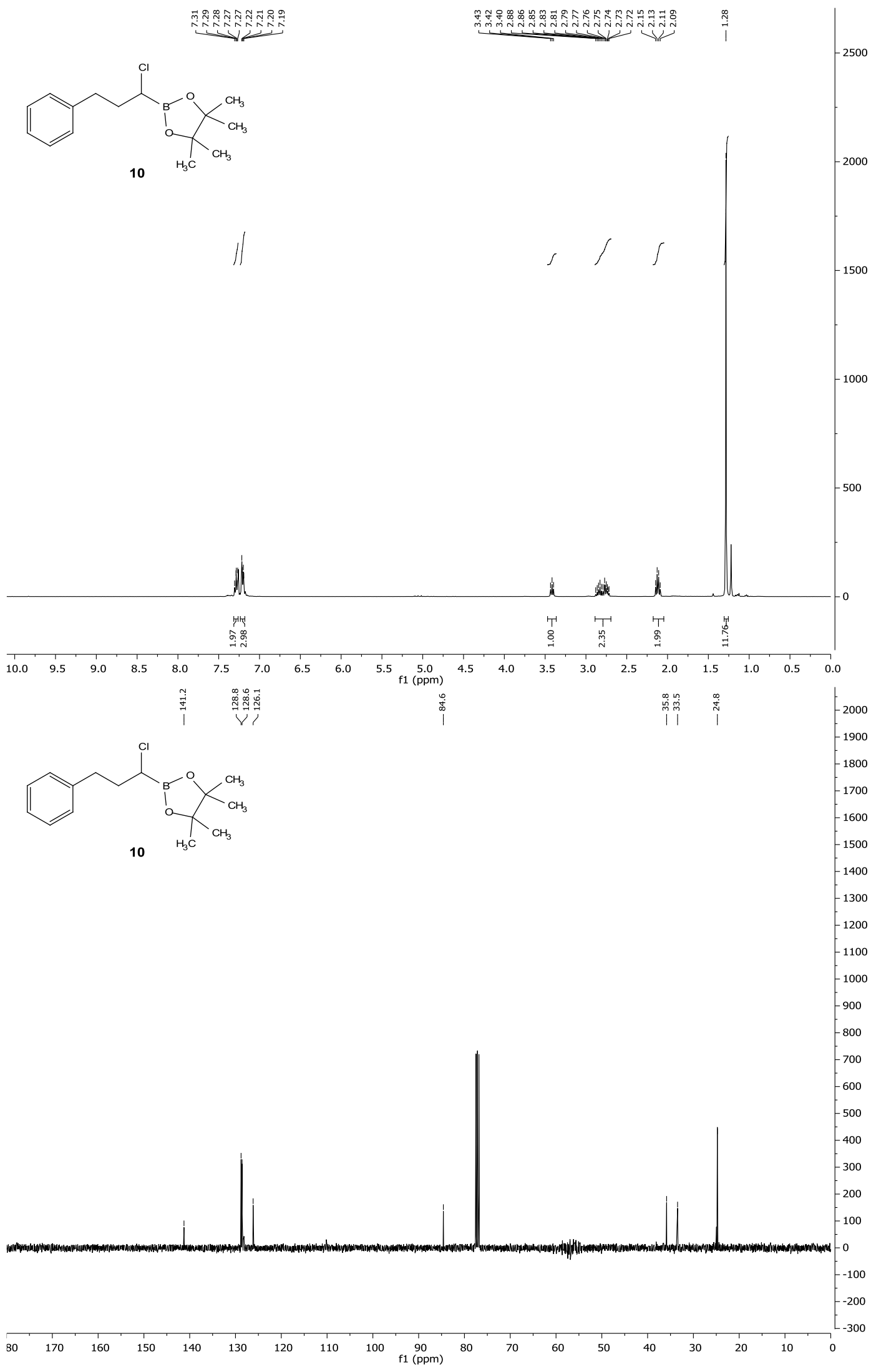

